\title{
Régészeti feltárások Somogy megyében 2007-2011 között
}

\author{
HONTI SZILVIA, HAJDÚ ÁDÁM DÁVID, KÖLTŐ LÁSZLÓ, MOLNÁR ISTVÁN, \\ NÉMETH PÉTER GERGELY és SIPOS CARMEN
}

Rippl-Rónai Múzeum

H-7400 Kaposvár, Fő u. 10., e-mail: honti@smmi.hu

Honti, Sz., Hajdú, Á. D., Költö, L., Molnár, I., Németh, P. G. \& SIPOS, C.: The article comprises the short description of excavations in Somogy county beetween 2007-2011.

Abstract: Linearbandkeramik and Lengyel Culture: Barcs-Somogytarnóca-Aszalói dűlő, Barcs-Somogytarnóca-Sertésteleptől ÉNy-ra, Hollád, Komlósd-Mogyorós (settlements); Balaton-Lasinja Culture: Gyékényes, Lulla-Büdösalja (settlements); „Furchenstich" ceramic Culture: Barcs-Somogytarnóca-Aszalói dülő, Istvándi-Csontai-dűlő (settlements); Baden Culture: KaposvárKisgát, Lulla-Jabapuszta (settlements); Somogyvár-Vinkovci Culture: Hollád, Lulla-Büdösalja, Lulla-Jabapuszta (settlements), Zamárdi-Réti földek (grave), Kaposvár-Kaposfüred 67/13 (settlement); Kisapostag Culture: Barcs-Somogytarnóca-Aszalói dülö, Kaposvár-Kisgát (settlements); Urnfield Culture (earlier and elder period): Vörs-Battyáni disznólegelő (cemetery), Barcs-Somogytarnóca-Aszalói dűlő, Gyékényes, Hollád, Siófok (settlements); Hallstatt Culture: Kaposvár-Kaposfüred 67/13, Siófok (settlements); Celtic age: Barcs-Somogytarnóca-Aszalói dűlő, Gyékényes, Lulla-Büdösalja (settlements), Kaposvár-Kaposfüred 67/13 (graves); Roman age: Barcs-SomogytarnócaAszalói dűlő, Balatonszentgyörgy (Vörs-B), Gyékényes-Fehérdülö, Kaposvár-Kisgát, Lulla-Büdösalja, Sávoly (settlements), Somogyvár-Bréza-erdő (barrow grave), Lulla-Jabapuszta (settlement, first-third centuries); Avar period: Vörs-Battyáni disznólegelö, Kaposvár-Kertészet, Zamárdi-Réti földek (cemeteries), Siófok (settlement); 10-11 th centuries: Hollád (settlement), Kaposvár-Kertészet (cemetery); Arpadian-age: BarcsSomogytarnóca-Aszalói dűlő, Hollád-Körforgalom, KaposvárKaposfüred 67/12, Komlósd-Mogyorós, Lulla-Büdösalja (settlements), Iharos-temető, Kisberény-Helai-dülö, Szőkedencstemető (churchs, cemeteries); Late medieval period: Iharostemető, Kisberény-Helai-dülő, Szőkedencs-temető (churchs, cemeteries), Lulla-Büdösalja (settlement); Early new ages: Kaposvár-Kisgát (cemetery), Őrtilos-Új Zrinyi vár (fortress)

Keywords: bone salt-cellar, gemma, avars grave with a sidewall niche, rotunda

Tanulmányunkban a Somogy Megyei Múzeumok Igazgatósága régészeti osztályának 2007-2011 között végzett feltárásairól számolunk be. Ezekben az években kevesebb nagyberuházáshoz kapcsolódó, nagyfelületű feltárás volt megyénkben, ráadásul - a törvényi környezet megváltozása miatt - ezek egy részét is a Kulturális Örökségvédelmi Szakszolgálat végezte. Ezért a megelőző időszakhoz képest az általunk feltárt területek nagysága valamivel csökkent, de így is több, igen jelentős eredményt hozó ásatást folytattunk. A lecsökkent létszámú régészeti osztály ezek mellett az elmúlt évek ásatásainak feldolgozását is végezte, valamint a múzeum és a raktárak költöztetésén is dolgozott.
A feltárások egy része még az előző évek nagyobb útépítéseihez kapcsolódott, körforgalom kiépítése és pályakorrekció miatt ástunk Siófokon és Holládon. Az időszak legfontosabb, legnagyobb felületeket érintő feltárása a Balatonendréd - Lulla összekötő út megépítéséhez kapcsolódott, négy lelöhelyen $27000 \mathrm{~m}^{2}$ felületet tártunk fel a lullai szakaszon. Itt is a Szakszolgálattal illetve jogutódjával a Magyar Nemzeti Múzeum Kulturális Örökségvédelmi Központjával dolgoztunk együtt, ahogyan a 61-es út Kaposfüredet elkerülő szakaszán és a sávolyi MotoGP-pálya tervezett területén. Több alkalommal a feltárások magánberuházásokhoz kapcsolódtak, így Kaposvár-Kertészetben, Zamárdi-Réti-földeken, és Kaposvár-Kisgáton. Máskor közművezetékek fektetése előtt végeztünk ásatásokat - többször ezeknél is több ezer négyzetméteres terület került feltárásra.

Nagy örömünkre szolgált, hogy több alkalommal a helyi közösséggel együttmüködve és anyagi támogatásával sikerült igen értékes feltárásokat végezni. Kisberény-Helai-dűlő, Iharos-temető és SzőkedencsTemető lelőhelyeken kisebb-nagyobb templom és temetörészleteket tudtunk feltárni ilyen módon.

Összességében elmondhatjuk, hogy az elmúlt években - az 1-2 napos leletmentésektől, a szakfelügyeleti feltárásokon és tervásatásokon át, a nagyberuházás előtti megelőző feltárásokig - igen sokrétü munkát végeztünk, ennek során a néhány négyzetméterestől a tízezer négyzetméter feletti nagyságú lelőhelyeken, szinte minden - Somogy megyében megtalálható - régészeti korszakról sikerült újabb adatokat szereznünk (1. ábra).

\section{Hollád, Körforgalom}

(Molnár István)

2007-ben Holládtól délre körforgalom és útkorrekció megépítésére került sor. Ennek munkálatait ellenőriztük, amikor objektumokat észleltünk. 2007. augusztus 6 -án megkezdtük a feltárást ${ }^{1}$, a munkálatok kisebb megszakításokkal szeptember 21-ig tartottak. Négy különféle öskori kultúra mellett a középkor két időszakának objektumait bontottuk ki. A feltárt terület az útkorrekció munkáihoz igazodott. A terület déli, Cser-völgyi pataknál lévő részén, a körforgalom délkeleti területén, valamint az észak-déli irányú út két oldalán egy-egy keskeny sávot jelentő útkorrekció területén találtunk objektumokat. Az utóbbiak az útkorrekció északi és déli részén 80-100 méter hosszan csoporto-

1 A feltáráson részt vett: Molnár István, dr. Honti Szilvia, Németh Péter Gergely (régészek), Ambrus Edit, Balla Krisztián, Cserép Tamás, Gál Zoltán, Nyári Zsolt (technikusok) 


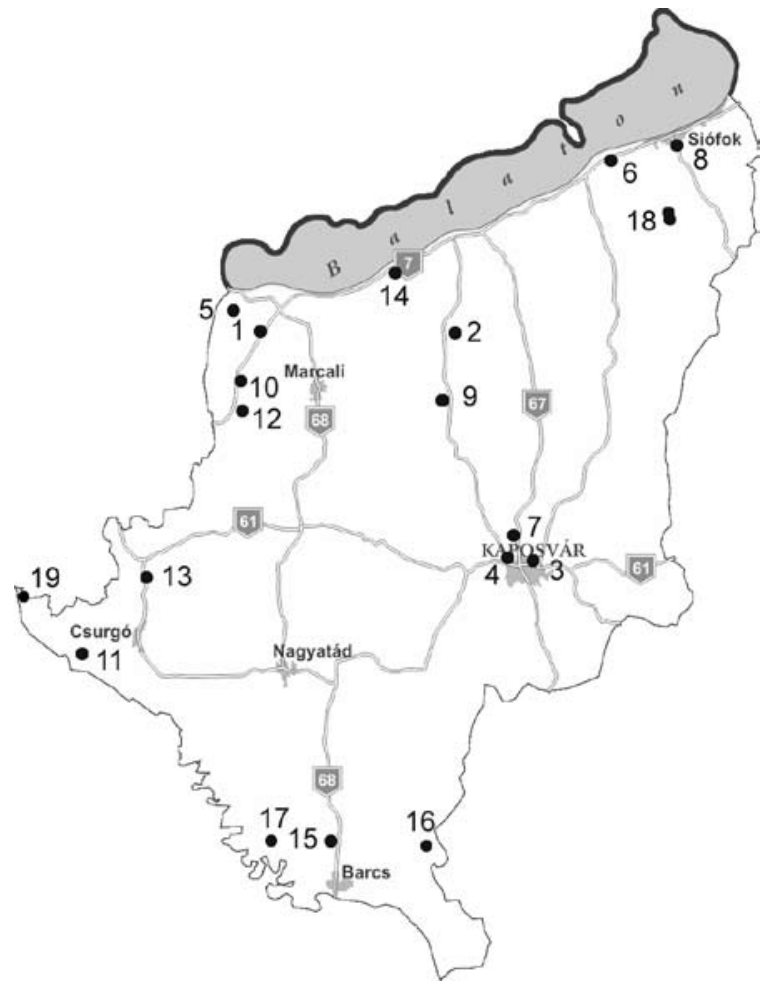

1. ábra: A bemutatott lelöhelyek elhelyezkedése: 1. HolládKörforgalom, 2. Kisberény-Helei-dülö, 3. Kaposvár-Kisgát, 4. Kaposvár-Kertészet, 5. Balatonszentgyörgy-Batthyány disznólegelö, 6. Zamárdi-Réti földek, 7. KaposvárKaposfüred-67/13 lelöhely, 8. Siófok-Körforgalom, 9. Somogyvár-Breza erdő, 10. Sávoly-Kerekeskúti-dülö, 11. Gyékényes-Fehér-dülö, 12. Szőkedencs-Temetö, 13. Iharos-Temetö, 14. Fonyód-Várhegy, 15. BarcsSomogytarnóca-Aszalói-dülő és Sertésteleptől ÉNy-ra, 16. Istvándi-Csontai-dülő, 17. Komlósd-Mogyorós, 18. LullaBüdösalja, Lulla-Jabapuszta DK, és Lulla-JabapusztaJóreménység TSz 19. Örtilos-Zrínyi-Újvár

sultak, köztük egy nagyjából 110 méteres szünet volt. A területnek csak egy részét tudtuk iszapoló kanállal leszedetni. Azokon a részeken, ahol az objektumok felfedezéséig körmös kanál dolgozott - a régészeti jelenségek minél teljesebb megőrzése miatt - kézzel nyestük újra a területet.

A lelőhely legkorábbi időszakát a neolitikus Dunántúli Vonaldíszes Kerámia településének maradványai jelentik. Néhány kisebb-nagyobb gödör mellett egy nagyméretü, szabálytalan alakú objektumot találtunk ebből az időszakból, elsősorban a lelőhely déli részén, a körforgalomnál illetve az útkorrekció délnyugati és délkeleti sarkában. A Lengyeli-kultúra időszakához több, viszonylag sok leletanyagot tartalmazó gödör tartozott. Szép, vörös festésű edények, talpas tálak töredékei kerültek elő ezekben az objektumokban.

A terület északi részén egy gödör a kora bronzkori Somogyvár-Vinkovci kultúra időszakára, délen egy gödör a késő bronzkorra, a késő halomsíros - kora urnamezős időszakra volt datálható.
Találtunk egy zsugorított csontvázas rítusú őskori sírt is, amelynek pontos kora melléklet hiányában nem volt megállapítható. Előkerült egy nem szabályosan eltemetett, csak gödörbe dobott, szintén ismeretlen korú emberi váz is.

A terület legdélebbi részén, a körforgalom területén egy 10-11. századra keltezhető település kevés maradványát azonosítottuk: Egy előtérgödörrel és csak gyengén átégett tűztérrel rendelkező tüzelőberendezést (II. t. 5.), egy lekerekített sarkú téglalap alakú, két ágasos, szelemenes szerkezetű épületet (II. t. 6.), és egy biztosan, valamint két feltételezhetően erre az időszakra datálható gödröt tártunk fel. Ettől a területtől jelentősen északabbra, az útkorrekció északkeleti és északnyugati oldalán egy késő Árpád-kori, 13-14. századi település maradványait találtuk meg. 44 objektum - gödrök, cölöplyukak, árkok biztosan, mintegy 30 feltételesen erre a korszakra tehető. Innen északkeletre - a Balatonszentgyörgy-Almási úti dűlő 3. nevű régészeti lelőhelyen (HoNTI et al. 2006.11.) - elszórt 13-15. századi településnyomok voltak. Ettől keletre 100-150 méterre a középkori település központjára a terepbejárások során elökerült nagy mennyiségü kerámia utal, a templom maradványai a Szentegyházidombon találhatók. Megállapítható, hogy nagy kiterjedésű középkori lelőhelyröl van szó, amelynek változó intenzitása a középkori településszerkezet sajátosságai mellett erős lekopottságának köszönhető. A körforgalom területén lévő nagyszámú, sürün elhelyezkedő, de sekély objektum is erre utal. A gödrök, árkok szép leletanyagot tartalmaztak: a számos fazék, bográcstöredék mellett több kés, egy sarkantyú, vassalak is előkerült a betöltésükből.

\section{Kisberény-Helai-dülő}

(M. Aradi Csilla)

A falutól ÉNy-ra fekvő Kisberény-Helai-dűlő nevű területen, az erdő szélén emelkedő kis kiemelkedést a Rippl-Rónai Múzeum Adattára alapján már korábban azonosították Berény falu templomhelyével, ahol még a 20. század elején egy félköríves szentélyzáródású templom $5-6$ soros téglafala is látszott. ${ }^{2}$ A területen helyszínelésünk alkalmával beásásokat, kutatógödröket, szétszórt téglatörmeléket, középkori kerámiatöredékeket észleltünk.

Az akác- és mogyorónövésektől megtisztított terület feltárására 2008. április 14. és 25.-e között került sor. ${ }^{3}$ $A z$ érintett területen egy É-D-i irányú és két $\mathrm{K}-\mathrm{Ny}$-i irányú kutatóárkot húztunk, hogy a templomfalak vonalát tisztázhassuk. A II. sz. kutatóárokban előkerült a templom É-i falának vonala, amely azonban ÉK-DNy-i tájolása miatt csak részben esett bele a kutatott területbe. $A$ fal $\mathrm{K}$-i részén érdekes falcsatlakozást figyelhettünk meg: az erösen habarcsos hosszanti É-i falat egy korábbi centrális alaprajzú, téglafalú épületre (kerek templom) falazták oly módon, hogy a korábbi épület keleti

2 Rippl-Rónai Múzeum Adattára II/15/1., 3., 6. Magyar K. helyszínelése. KoczTUR 1964. 79. VÉGH 1974. 23/35. 108

3 A feltáráson részt vett: Aradi Csilla, Molnár István (régészek), Balla Krisztián, Nyári Zsolt (rajzolók) A kisberényi önkormányzat és Rózner lbolya segítségéért köszönetet mondunk. 


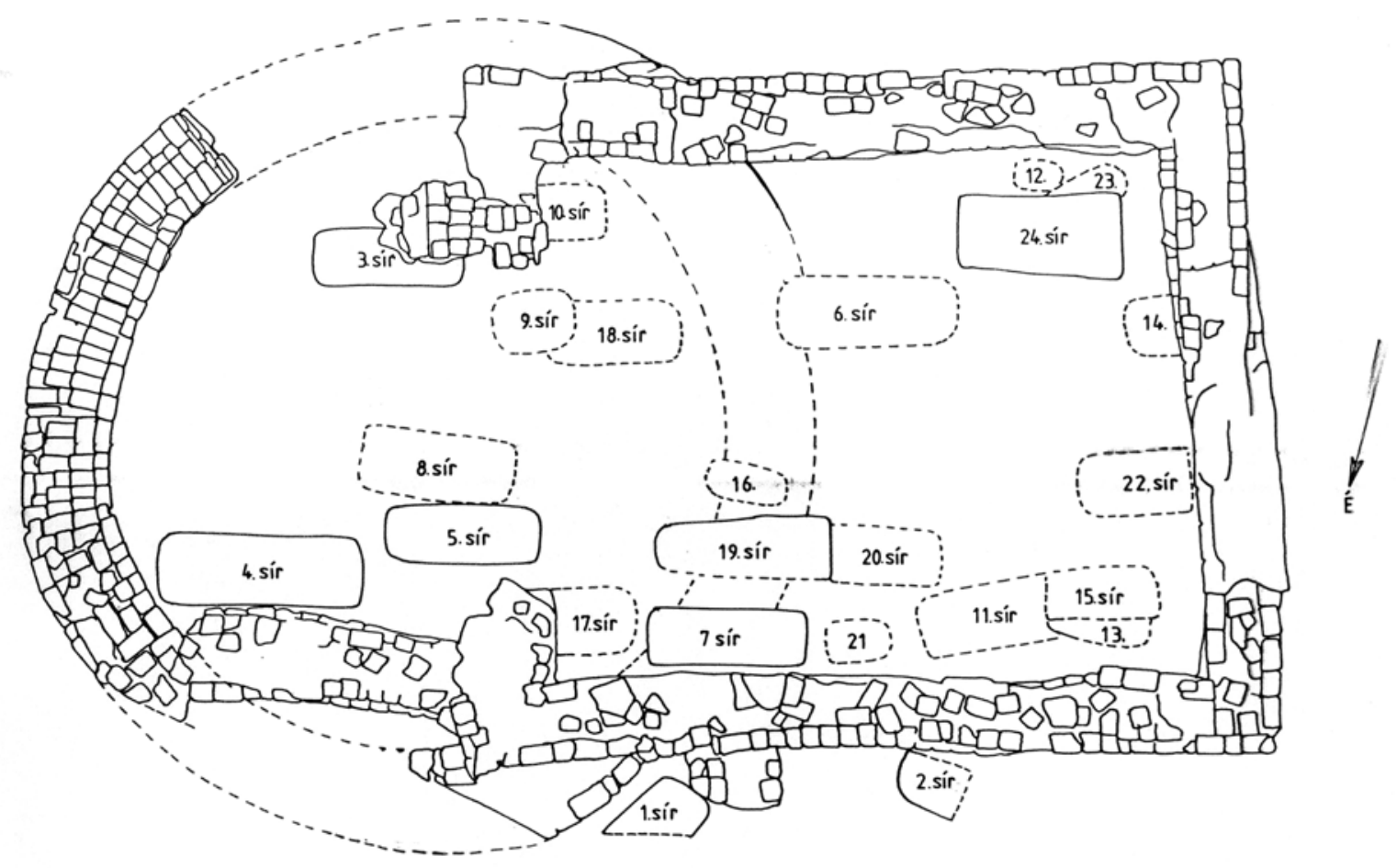

2. ábra: Kisberény - Helai-dülő, a templom alaprajza

falszakaszát a nyújtott szentélyű apszis kialakítása során felhasználták. Az agyagba rakott téglaalapozású, 1. periódusú templom - rotunda - bejárata DK-ről lehetett, mivel itt az alapozásban hiátust észleltünk, azonban beásásra utaló nyomot nem találtunk. Míg a kerektemplom É-i falalapozását meghagyták, a déli oldalon csak a kiszedett alapozási árkot figyelhettük meg. A 2. periódusú templom, az előzőnél jóval nagyobb volt, nyújtott szentéllyel, félköríves szentélyzáródással és feltehetően $\mathrm{Ny}$-i kapuval rendelkezett (innen a törmelékes anyagból egy küszöbkő került elő). A templom felmenő falait erősen habarcsos kötőanyaggal, leginkább téglából, de néhol kőből rakták. A diadalív alapozás környékéről nagyméretü bazalt kövek kerültek elö. (2. ábra)

Vélhetően a recens bolygatások okán az I. kutatóárok $D$-i végében, összefüggő területen, nagy számban összeszórt embercsont töredékét észleltük. A későbbi beásások miatt eredeti helyzetében csak 22 sírt tudtunk a 2. periódusú templomon belül feltárni, míg 2 sír maradványait a templomon kívül dokumentáltuk. A 3, 10, 14. és 17. sírban fekvő csontvázakat a 2. periódusú templom építése során megbolygatták. A leggazdagabb (5.) sír a templom szentélyéből került elő. A halottat egy bronz lemezekkel díszített övvel együtt temették el (I. t. 1-2.), melynek napsugaras és indadíszes vereteit, áttört díszű szíjvégét, téglalap alakú csatját eredeti helyzetében - a derékon keresztezve, majd az öv végét a csaton átvetve - találtuk meg. Az eltemetett a kezén 3 gyürüt is viselt, a sír földjéből pedig Luxemburgi Zsigmond parvusa került elő. Ezzel együtt összesen 9 pénzérmét gyűjtöttünk az ásatás területéröl, melyek között négy Zsigmond, két aquileiai II. Antal, egy osztrák V. Albrecht, egy bajor IV. Henrik érme a 14-15. sz. fordulójára datálja a temetkezések többségét. A temető és a templom további használatára utal a 16. sírban talált, 1634-ből származó II. Ferdinánd dénár.

A templom törmelékes rétegéből két faragott kő töredéke is elökerült. $A z$ egyik kövön látható, négylevelü, csúcsos faragványok sorából álló díszítés folytatását (amely valószínüleg a 2. periódusú templom párkányát, esetleg valamely nyílását díszíthette) a helytörténeti kutatásokat is végző, azóta elhalálozott Élő Mihály korábban a Polgármesteri Hivatalba szállította. A másik, sakktáblaszerüen fogazott díszítésü kővel együtt, a faragványok legközelebbi párhuzamai a somogyvári bencés apátság területéről kerültek elő (BAKAY 2011. 116, 119.). A törmelékböl ezen kívül javarészt középkori kerámiaanyagot (pl. fedők), de néhány darab Árpád-kori fazéktöredéket is találtunk. Nagy számban kerültek elő koporsószögek és fehér színủ vakolatdarabok.

1193-ban a falu Somberény formában szerepel a forrásokban. A középkor folyamán ezenkívül Bikacsvagy Farkberénynek is nevezték, és a székesfehérvári káptalan, a johanniták, az Ugali, majd a Battyáni család birtokolták (CSÁNKI 1890 II. 592., DL 27). 1229-30-ban a somogyi tizedperrel kapcsolatban templomos helyként említik (Mon. Rom. I. 83., PRT I. 157, 692.). A pápai tizedjegyzék szerint a somogyi föesperesség alá tartozó plébánia papja, Miklós 1333-34-ben 20-20 kis D tizedet fizetett (Mon. Rom. II. 69., Mon. Vat. I/1. 393.). Az egy- 
ház Szt. Demeter titulusa 1334. szeptember 10-én szerepel első ízben a forrásokban (eccl. Sancti Demetrii de Kyusberyn), papja ekkor Jakab (sacerdos) (HO III. 123.). 1337-ben még mindig Jakab a falu papja (KuMOROVITZ 1953. 117.). 1341-43 között három ízben is hallunk Jakab kisberényi káplánról, aki feltehetően csak névrokona volt az előzőnek (KumOROVITz 1953. 138, 140, 149.). 1368. szeptember 4-én értesülünk arról, hogy Mathi Miklós és Pál Maróti Péter magisternek a kisberényi birtokrésszel kőből épült egyházát (ecclesia videlicet lapidea) is eladta (KuMOROVITZ 1953. 243. BORSA 1998. 37; DF 200991). Talán erre a Berényre vonatkoztathatjuk azt az 1425. december 19-i búcsúkérelemmel kapcsolatos oklevelet, ahol a parochiális egyház Pál nevű papját (rector) is megemlítik (LuKcsıcs 1931. 176.).

A feltárás eredményei és az okleveles adatok alapján feltételezhető, hogy az 1. periódusú templom már a 12. században megépült, majd, miután kicsinek bizonyult a 13. század folyamán a leírt módon bővítették. Támpillérre, sekrestyére, toronyra utaló nyomokat nem találtunk.

\section{Kaposvár-Kisgát III. ütem}

2008-ben kezdték meg Kaposvár kisgáti városrészében a Napsugár nevű lakópark építését, utak és közmüvek kiépítésével. Egy nagyobb lelöhelyet ismertünk már korábban is itt, a beruházó az út és körforgalom által érintett részén biztosította a megelőző feltárás anyagi fedezetét, a többi földmunkához felügyeletet biztosítottunk. A több éven át, több szakaszban folyó munkálatokat 2008. február 7-én kezdtük meg.

\section{Kaposvár-Kisgát III. ütem 1. lelőhely} (Molnár István)

Először a lelőhely területének északi részén lévő út nyomvonalában húztunk körülbelül három méter széles kutatóárkot. Csak a kutatóárok nyugati végében találtunk egy feltehetően római kori objektumot, amelyet kibontottunk és dokumentáltunk. Ezután kezdtük a munkálatokat a délebbi utca nyomvonalában. Itt is kutatóárkot húztunk, már az első nap régészeti objektumokat találtunk. Ezután a géppel kibővített felületen 2008. február 15-től a kivitelezőtől kapott munkások segítségével megkezdtük az objektumok bontását. ${ }^{4}$

A feltárás 2008. április 2-ig tartott. 95 objektumot bontottunk ki. A déli út és körforgalom nyomvonalában körülbelül $3400 \mathrm{~m}^{2}$ felületet nyitottunk meg, amely objektumokkal sürün fedett volt. Később 2008-ban majd 2009-ben is megfigyeltük a terület más részein folyó munkálatokat, ennek során több helyen is újabb régészeti jelenségeket találtunk. Megállapítottuk hogy a lelőhely északra, délre és keletre is folytatódik. Így több szakaszban összesen 116 objektum került feltárásra.

A feltárt objektumok többsége a bronzkorra, a Kisapostagi-kultúra időszakára volt keltezhető. Két hatalmas méretű (körülbelül 20 méter hosszú), mély, szabálytalan alakú objektumot bontottunk ki (II. t. 1.).

4 A kisgáti feltáráson részt vett Molnár István, Németh Péter Gergely (régészek), Ambrus Edit, Balla Krisztián, Cserép Tamás, Gál Zoltán, Nyári Zsolt (technikusok)
Elökerült több nagyobb méretü, kerek, méhkas alakú tárolóverem, valamint számos kisebb-nagyobb gödör. A bronzkori objektumok igen gazdag leletanyagot tartalmaztak. A nagy mennyiségü, gyakran mészbetétes díszítésü kerámiatöredék között több ép illetve kiegészíthető edényt találtunk (I. t. 3-4.), ezek mellett több kő- és bronzeszköz (kőbalta, bronz tü) darabja is előkerült.

Négy gödör a Baden kultúra időszakára (I. t. 5.), a lelőhely objektumainak fennmaradó része a római korra volt keltezhető. Két árok mellett 21 kisebb-nagyobb gödröt tártunk fel. Ezek is bőséges leletanyagot tartalmaztak. A több kiegészíthető edény - közte nagy hombárok - töredékei mellett több vastárgyat találtunk bennük. A feltárás befejezése után, szakfelügyelet végzése közben, 2008. áprilisban egy, a feltáráshoz viszonylag közeli közmüárokban római tüzelöberendezést találtunk. Sajnos a középső része hiányzott, az árok lerombolta. A téglalap alakú objektumnak erősen átégett platnija és fala volt - valamilyen égetőkemence lehetett. A felső része, esetleges rostélya teljesen elpusztult. Egy elszenesedett fahasáb maradványa is volt benne.

\section{Kaposvár-Kisgát III. ütem 2. lelőhely}

(Molnár István)

2008. április 7-én, a terület északkeleti részén végzett vízvezeték-árok ásása során a kotró két csontvázas sírt bolygatott meg. Másnap ezeket kibontottuk és dokumentáltuk. Áprilisban és májusban újabb közmüárkok ásása és az út nyomvonalának humuszolása során újabb hat sír került elő. 2009. március 2-án gázbekötések ásása közben még két temetkezést találtunk. Összesen tehát 9 sírt tártunk fel, sajnos a közműárkok általában rombolták ezeket (II. t. 2.). A temetkezések egymás közelében, nagyjából sorokba rendeződve helyezkedtek el. Nyugat-keleti tájolású, háton fekvő, nyújtott helyzetü vázak voltak. Több fülesgomb mellett egy vaskés és két csizmapatkó volt a csontok mellett. Úgy véljük egy temető déli szélét találhattuk meg, amely északkeletre folytatódhat. Templomra utaló jelet, téglamaradványokat nem láttunk a területen. A temető kora újkorra keltezhető, teljesebb feltárása esetén Kaposvár korabeli történetének értékes forrása lehet.

\section{Kaposvár-Klebelsberg kollégium}

(Németh Péter Gergely)

2010. áprilisában, a kisgáti városrészben, a Desedapataktól keletre, a lelőhely északnyugati részén, földmunkát végeztek. Leletmentés során 6 római kori gödröt tártunk fel. Az objektumokban lévő kevés kerámiatöredék között márványozott festésű, valamint terra sigillata töredékek is voltak. Az egyik gödörben érmét is találtunk. Szórványként több római érme, valamint bronz- és vastárgy is elökerült.

\section{Vörs-Battyáni-disznólegelő („Vörs-B”) \\ (Honti Szilvia)}

A kis-balatoni program keretében a lelőhelyen 19852000 között végzett kutatások során több ezer $\mathrm{m}^{2}$-en, 1353 objektumot tártunk fel. A Kulturális Örökségvédelmi Hivatal támogatásával a lelőhely keleti részén, a 
bronzkori és avar kori temetők folytatását - esetleges záródását - szerettük volna felderíteni. A feltárás fontosságát kiemeli az, hogy a bronzkori temetkezések a felszínhez közel vannak és a mezőgazdasági művelés veszélyezteti azokat.

A 2008. évi feltárás során összesen $540 \mathrm{~m}^{2}$-es felületen 45 objektumot tártunk fel (1354-1398. objektumok). Az Urnamezős kultúra 20 hamvasztásos rítusú sírjának többsége urnás volt, néhány szórthamvasztásos rítusú mellett. A különböző formájú urnákat gyakran tál fedte, erre a halotti máglyán megégett edények (1-1 fazék, csésze) töredékeit szórták, az ép csésze sírba helyezése ritka (II. t. 3.). A sírok igen eltérő mélységben kerültek elő: Némelyiküket a szántás elérte, megsértette, másokat mélyebb, kerek sírgödörbe helyezték. A kevés "gazdagabb", bronz-mellékletes sírban különféle karikaékszerek a jellemzőek.

Két padmalyos szerkezetű 9. századi avar sír került elő (II. t. 6), a kevés számú mellékletből kiemelkedik egy díszített agancs sótartó (I. t. 6.). A sírok viszonylag nagyobb távolságra vannak a korábban előkerültektől, esetleg egy újabb csoport kezdetét jelzik. A temetkezések mellett feltárt bronzkori és római kori telepobjektumok szerény leletanyagot szolgáltattak.

A feltárás eredményei alapján megállapítható, hogy a lelöhely keleti szélét elértük, ebben az irányban sem a települések, sem a temetők nem folytatódnak. Az újabb bronzkori és avar sírok azonban azt jelzik, hogy mindkét temető északi irányban folytatódik (illetve folytatódhat). ${ }^{5}$

\section{Zamárdi - Réti földek}

(Molnár István)

Somogy megye egyik legfontosabb régészeti lelöhelye a Zamárdi-Réti földeken található avar temető. 2008ban egy eladásra szánt telek területén kisebb feltárást végeztünk. ${ }^{6}$

A lelöhelyen, Bárdos Edith vezetésével, több éven keresztül folytak ásatások az 1980-as 90-es években. A mai Rétföldi utca kiépítését megelőzően feltárta a temetőnek az utca nyomvonalába eső részét, így ismertük a temető $\mathrm{K}-\mathrm{Ny}$-irányú kiterjedését. Az utcától délre kialakított új telkek területén folyt a feltárások zöme. Ennek során egy igen jelentős - nemzetközi hírü - avar temető két és félezer sírja került feltárásra (BÁRDos-GARAM 2009.). Az általunk kiásott temetőrészlet a temető ÉNy-i sarkában, az utcától északra található, a nemrég felparcellázott ún. Papi-földeken. Ennek északi részén, a templom közelében található a Zamárdi-Templomtóldélre nevű lelőhely, ahol 2006-ban egy késő-középkori településrészlet került feltárásra. Elképzelhető volt, hogy a telek északi vége esetleg eléri ezt a lelöhelyet is, azonban a földmunkák során bebizonyosodott, hogy a középkori telep nem ér el idáig.

$5 \quad$ Az ásatáson részt vett Molnár István és Németh Péter Gergely régész, Gál Zoltán adattáros, Cserép Tamás ásatási technikus, Ambrus Edit, Balla Krisztián és Nyári Zsolt rajzoló.

6 A feltáráson részt vett Molnár István, Németh Péter Gergely (régész), Balla Krisztián, Cserép Tamás, Gál Zoltán, Nyári Zsolt (technikusok, rajzolók). A telek tulajdonosának Varga Lászlónak köszönjük régészeti örökségünk védelméhez való pozitív hozzáállását, akinek jelentős anyagi támogatása tette lehetővé a feltárást.
A munkálatokat 2008. október 16-án kezdtük meg és november 13-án fejeztük be. Megállapítottuk, hogy az avar temető a telek déli harmadára terjed ki. $528 \mathrm{~m}^{2}$-en 85 avar sírt bontottunk ki (III. t. 5.). A sírok jelentős részét kirabolták (III. t. 6.), de bolygatatlanokat is találtunk közöttük. A csontok megtartása különböző volt, több gyermeksírban nem maradtak meg. A sírokban nagyszámú melléklet volt, több kifejezetten gazdagnak tekinthető. A csatok, kések, tütartók mellett, a férfi sírokban övveretek, szíjvégek, a női sírokban fülbevalók, gyöngysorok voltak a legtöbbször előforduló mellékletek, de találtunk nyakperecet és egy lándzsacsúcsot is. A halottak egy részét koporsóban temették el, ezekre a sok koporsóvas utalt. Néhány koporsót a fejnél és a lábnál keresztekkel díszítettek. A temetőrészlet jól illeszkedik a korábban feltárt sírokhoz, a temető északi határának pontosabb kijelölésében volt segítségünkre a feltárás.

$\mathrm{Az}$ avar sírok között találtunk egy bronzkori, a Somogyvár-Vinkovci kultúrához tartozó hamvasztásos, edénymellékletes sírt is, a feltárt terület nyugati részén (III. t. 1-2.). Metszette egy újkori árok és egy avar sír, amelyet ráadásul ki is raboltak, ezzel is tovább bolygatva a területet, így a különben rabolatlan sír súlyos károkat szenvedett. A sírgödör négyzet alakú volt, a fala függőleges, az alja ívelten mélyült a közepe felé. Tájolása a nyugat-keleti tájolástól kissé délnyugatra eltért $\left(280-100^{\circ}\right)$. Rítusa szerint szórthamvasztásos temetkezés, ahol a hamvakat a sír közepére szórták le, az avar sír elvitte egy részüket. A sírgödör déli és északi sarkába helyezték az edényeket (III. t. 3-4., I. t. 7.). Az északi sarkához közel egy belsődíszes, talpas tál, a déli sarkában egy gömbös testü, hengeres nyakú, kétfülü fazék, egy kónikus tálka, 4 kis pohár és egy gömbös testü kisedény állt. A földjéből egy réz (vagy bronz) nyílhegy került elő. A sír még így, hiányos voltában is nagyjelentőségü: ebből a kultúrából nagyon kevés temetkezés ismert, hitelesen feltárt, jól megfigyelt pedig még kevesebb. A Balaton túlsó végében Szőkedencsről urnás rítusú sírok ismertek, míg ez szórthamvasztásos. A sírgödör mérete, az edények nagy száma, s leginkább a ritka fémtárgy az ide eltemetett magas vagy különleges társadalmi helyzetére utal.

\section{A 67. sz. főút Kaposfüredet nyugatról elkerülő sza- kasza}

A67. számú főút Kaposfüredet elkerülő szakaszának megépítése elött, a Kulturális Örökségvédelmi Szakszolgálat megbízásából a Somogy Megyei Múzeumok Igazgatósága végzett régészeti munkálatokat. A 2007. évi terepbejárások során két helyen találtunk kerámiatöredékeket, egy lelőhelyen a 61-es út Kaposvárt elkerülő szakaszának építését megelőzően folyt feltárás. Ezen a három ponton kezdtük meg - kutatóárkokkal - 2008. novemberében a munkálatokat. Két lelöhelyen - 61/8. és $67 / 12$. lelőhely - nem találtunk régészeti objektumot, a $67 / 13$. lelőhelyen viszont eredményes volt a feltárás. ${ }^{7}$

7 A 67-es elkerülő út megelőző feltárásain részt vett: 61-es út 8 és 67/12. lelöhely Honti Szilvia (régész), Ambrus Edit, Rozner Ibolya (technikusok) 67/13. Ih.: Molnár István (régész), Nyári Zsolt (technikus). A gépi és kézi munkaerőt a KÖSZ biztosította a feltárásokra. 
Később - 2009-ben és 2010-ben - az útépítés szakfelügyelete során újabb régészeti objektumok kerültek elő két helyen.

\section{Kaposvár-Kaposfüred-67/13. lelöhely}

(Molnár István)

A lelőhely Kaposfüred lakóterületétől mintegy 200 m-re északnyugatra található. A terepbejáráson későközépkori kerámiát találtunk a területen, ennek alapján félpályás feltárást indítottunk, a leletcsoportosulásnak megfelelően egy kisebb felületen keleten, és egy nagyobbon nyugaton. A munkálatokat 2008. november 14-én kezdtük meg a nyugati területen. A nyomvonal déli sávjában húztunk egy kutatóárkot, amit a későbbiekben észak felé bővítettünk. Mivel a terület nyugati sarkában nem voltak objektumok, ezen a részen nem nyitottunk újabb felületet. Összesen közel $4000 \mathrm{~m}^{2}$-en négy régészeti korszak objektumait tártuk fel.

A kora bronzkorra és a vaskorra, a SomogyvárVinkovci-kultúra és a Hallstatt-kultúra időszakára volt keltezhető az objektumok nagyobb része, ezek nagyjából két észak-déli irányú sávban helyezkedtek el a dombtetőn. Leletanyaguk igen szegényes volt, nagyobb részük csak betöltése alapján volt keltezhető. A kisebbnagyobb gödrök, oszloplyukak közül hat egy csoportot alkotott, a két párhuzamos sorban elhelyezkedő 3-3 objektumban talán valamilyen felszíni épület oszlophelyeit sejthetjük. Hasonló, sorokban elhelyezkedő cölöplyukakat találtunk nagyjából 30 méterre keletebbre is, talán itt is egy hasonló, a másikkal megegyező tájolású építmény állhatott.

A területen két kelta sírt tártunk fel, amelyek a kései időszakra keltezhetőek az egyik sír edénye és két vasfibulája alapján (IV. t. 1-3.). A sírok egymás mellett, délészakra tájolva feküdtek. Az egyik sír szabályos volt, a másikba rendellenesen, a hasára fordítva, kissé zsugorítva temették el az elhunytat. Mivel a sírok a feltárás közepén voltak, feltehetően nem egy nagyobb temető szélét találtuk meg, hanem magányos sírokról beszélhetünk. Néhány objektum a középkorra keltezhető.

\section{Kaposvár - Kapos-úti-dűlő (67/12. lelőhely) \\ (Németh Péter Gergely)}

2009 októberében az út építésekor Árpád-kori települési objektumok kerültek elő. Az erősen lepusztult felületen ezek elszórtan, egymástól nagy távolságra jelentkeztek. Jellegzetesek a nagyméretü, külsőkemencés objektumok: A három hamusgödörhöz 1, 2 illetve 4 kemence csatlakozott. A kemencék felmenő fala nem maradt meg, sütöterüket több esetben összetört edénytöredékekkel alapozták. A leletanyag nagy része fazéktöredék, az egyik kemencés objektumból vastárgyat gyűjtöttünk. Ezenkívül sekély gödöraljakat figyeltünk meg, ezekből kevés kerámiatöredék és állatcsont került elő. ${ }^{8}$

\footnotetext{
8 Munkatársaink voltak Balla Krisztán, Cserép Tamás, Gál Zoltán,
} Molnár István, Nyári Zsolt

\section{Kaposvár-Kaposfüred - Felső-erdő-dülő \\ (Molnár István)}

2010. júliusában a Juta-Kaposfüred közötti úttól délre, az épülő elkerülő út mellett kiásott árok oldalában régészeti objektumokat találtunk. Az útépítés során ezen a területen viszonylag sekély mélységben szedték le a felső humuszréteget, amire töltést építettek, így a régészeti objektumok nem kerültek felszínre. Az út mentén kiásott vízelvezető-árkok mélyebbek voltak, így fedeztük itt fel az objektumokat. Összesen négy, kora Árpád-kori gödröt találtunk, amelyeket az árok rombolt. Ezeket kibontottuk és dokumentáltuk. A két utóbbi lelőhely egy kis vízfolyás két partján helyezkedik el, feltehetően összetartoznak

\section{Siófoki körforgalom, az M7-es autópálya és a 65-ös} út új csomópontja

(Molnár István)

Az M7 autópálya és a 65 . számú föközlekedési út északi, körforgalmi csomópontjának építésekor a földmunkák idején régészeti megfigyelést végeztünk. Ennek során, a nyugati körforgalom-rész területén régészeti objektumokat találtunk. 2009. június 8-án megkezdtük a feltárást, amely a kivitelező kérésének megfelelően több szakaszban történt. Mivel az egész domb régészetileg fedett volt, ezért minden olyan területet, ahol földmunka folyt - összesen több mint $3000 \mathrm{~m}^{2}$-t - fel kellett tárnunk. ${ }^{9}$ A feltárás után a területeket szakaszosan adtuk át a kivitelezőnek.

Siófoktól délre egy - azóta az útépítés során elhordott - dombon helyezkedett el a feltárandó terület, az M7-es út északi oldalán. Az úttól délre a 80 -as években Költő László vezetésével későbronzkori és koravaskori teleprészletek mellett egy avar temetörészlet került feltárásra, az úttól északra pedig kelta telepnyomok. Feltehetőleg egy összefüggő lelőhelyről beszélhetünk, melynek a mai 65-ös út helyén lehetett a keleti széle, mivel ettől keletre sem a 80-as években sem 2009-ben nem kerültek elő leletek, azonban ezt a korábbi tereprendezések is magyarázhatják.

A területen késő bronzkori, kora vaskori és avar kori település objektumait tártuk fel. Összesen 103 objektum került felszínre. Az objektumok nagy többsége az őskorra keltezhető. A késő bronzkori Urnamezős-kultúra és a kora vaskori Hallstatt-kultúra településének számos gödrét, árkát, cölöplyukát bontottuk ki. A cölöplyukak egy része sorokat alkot, ezek egy épület szerkezetéhez tartozhatnak, a tartóoszlopok helyét jelölik. A gödrök viszonylag gazdag leletanyagot - nagyobb mennyiségü kerámiatöredéket, kevesebb állatcsontot - tartalmaztak. A lelőhely jelentőségét emeli, hogy a Hallstatt-kultúra településeit Somogyban viszonylag kevés helyen sikerült eddig feltárni. Két árok, valamint három kemence és ezek közös előtérgödre avar kori volt. A szabálytalan alakú, nagyméretü elötérgödörhöz csatlakozó kemencéknek (IV. t. 5.) hőtartó rétege nem volt, de az egyik tűzterében nagyobb köveket találtunk. Feltehetően a korábban feltárt temetőhöz (Siófok-M7/65-ös lelöhely) tartozó település objektumait találtuk meg.

$9 \quad$ A feltáráson részt vett: Molnár István, Sipos Carmen (régészek), Nyári Zsolt, Balla Krisztián, Gál Zoltán, Cserép Tamás (technikusok) 


\section{Somogyvár-Bréza-erdő}

(Németh Péter Gergely)

2008-ban a feltárás célja a nyolc halmot magába foglaló temető korának, valamint a rablottság szintjének kiderítése volt. Két sírdombot kutatóárokkal vizsgáltunk meg, mindkettő szerkezete azonos volt, koruk római kori. Mindkét halom közepén (az egyiknél sírgödörben) helyezték el a hamvakat, körülötte kevés edénytöredékkel. Megvizsgáltunk egy harmadik, csaknem teljesen elhordott halmot, ebben sok kőtöredéket találtunk, ez a temetkezés ez alapján kőpakolásos lehetett. Néhány római kori téglatöredék jelezte a temetkezés korát. A temetőhöz tartozó település a Pogányvölgyi vízfolyás túlsó oldalán található. ${ }^{10}$

\section{Sávoly-Kerekeskúti-dülő \\ (Németh Péter Gergely)}

Sávoly déli részén, 2008. november 4 . és 12 . között, szondázó ásatást végeztünk. ${ }^{11} 988 \mathrm{~m}^{2}$ területen, 14 régészeti objektumot tártunk fel. Az objektumok elszórtan jelentkeztek. Három objektum tartalmazott régészeti leletet. Ezekből a sekély gödöraljakból római kori kerámiatöredékek, nagyon sok állatcsont, kevés vassalak, kő- és téglatöredék került elő. A római gödrök közelében, több, lelet nélküli cölöplyukat tártunk fel, ezek feltételesen szintén a római kori telephez tartoznak. Később, a felület teljes humuszolását követően a Kulturális Örökségvédelmi Szakszolgálat munkatársai a római falusias jellegű település további, nagy felületen elszórt objektumait tárták fel.

\section{Gyékényes-Fehér-dülö}

(Molnár István és Németh Péter Gergely)

A drávai eredetű kavicsréteg kitermelésére kijelölt, több 10 hektárnyi területet kisebb dombok tarkítják, vastagabb földtakaróval, melyeken kisebb-nagyobb régészeti lelőhelyeket találunk. 2009-ben a leendő bánya északnyugati részén a rézkori Balaton-Lasinja kultúra 16 települési objektumát tártuk fel. Az objektumok elszórtan jelentkeztek. A cölöplyukak, gödrök és gödöraljak mellett egy hosszú, keskeny árkot is találtunk. Az árokból és cölöplyukakból minimális, míg a többi objektumból nagyon sok kerámiatöredéket, állatcsontot gyűjtöttünk. Az egyik gödörben csaknem ép, hordó alakú edényt találtunk (IV. t. 4.). A szondázó ásatás középkori objektumot nem eredményezett, bár a korábbi terepbejárásaink során több edénytöredéket találtunk az őskori teleptől délre.

A 2010. évi szondázó ásatás célja az őskori telep északi és keleti végének vizsgálata volt. A május 10 . - július 1. között végzett próbaásatás során kutatóárokkal behatároltuk az őskori telep északi részét, 3 rézkori (Balaton-Lasinja kultúra) telepobjektumot tártunk fel. A rézkori telep feltételesen a vasút északi részére is áthúzódik, azonban ezen a fedett területen bejárást végezni nem tudtunk.

10 Munkatárs: Ambrus Edit, Balla Krisztán, Cserép Tamás, Gál Zoltán Molnár István és Nyári Zsolt.

11 Munkatárs: Balla Krisztán, Cserép Tamás. 2010-ben a Fehér-dülő keleti részén újabb felület nyitására került sor. Itt $2900 \mathrm{~m}^{2}$ területen 100 őskori objektumot tártunk fel. Legnagyobb számban a BalatonLasinja kultúra sekély gödrei kerültek elő. Fazekak, tálak mellett díszített edénytöredékek is előkerültek. Az egyik rézkori gödörben szövéshez használt agyagnehezék töredékét találtuk meg. Két csiszolt kavicseszközt a helyben talált kavicsból alakítottak ki. Néhány gazdag leletanyaggal rendelkező gödör az Urnamezős Kultúrához tartozott.

Több cölöplyuk és kisebb gödör a kelták hagyatéka. A vaskori leletanyag döntő része kerámia (föleg tál- és fazéktöredékek), kevés vastárgy mellett. Az egyik, mélyebb gödröt paticcsal töltötték fel, ebben az objektumban egy díszített bronzgomb is volt. Egy kisebb gödörben töredékes vastüt találtunk.

A felszíni leletek alapján, az őskori telepek kelet felé, ha kisebb mértékben is, folytatódnak. Ezt a területet a kavicsbánya tervezett bővítése már nem érinti. A kavicsbányától délre nagykiterjedésü öskori, római kori és középkori telepet találtunk terepbejárás során. A felszínen gyűjtött leletek közül kiemelkedik egy féldrágakőből készült gemma, melyen két római katona alakja ismerhető fel. ${ }^{12}$

\section{Szőkedencs - Temető}

(Molnár István)

Megyénk egyik legszebb és méltán nagyhírü fája a szőkedencsi temetőben található úgynevezett „700 éves hársfa". A fa megóvása miatt szükségessé vált, hogy a gyökérzetére földet hordjanak, ehhez egy alacsony fallal vették körül a fát. Mivel a hagyomány szerint a település régi temploma itt, a ma is használt temetőben volt, a munkák során 2010 . augusztus 17-én és augusztus 18-án megfigyelést végeztünk.

A templomot az 1332-es pápai tizedjegyzékben említik először. A korábban mellette lévő - a budavári káptalan majd világi birtokosok tulajdonában lévő, Budaváridencs, később Vargadencs néven említett - település a török idöben elnéptelenedett, a 18. században kissé nyugatabbra települt újjá (CsÁNKI 1890. II. 600., ARADI 2007. kézirat). A templom is elpusztult, de a temető a régi helyén maradt, a mai napig használatban van.

2010. augusztus 17-én téglamaradványok kerültek elő. Megállapítottuk, hogy a fa köré tervezett körárok valószínüleg rombolná a templom maradványait. Elhatároztuk, hogy megkeressük a falakat a templom helyzetének tisztázására (IV. t. 7.). Egy ásónyom méIyen leszedtük a felső füves réteget a területröl. Ekkor kirajzolódtak a középkori templom keleti szentélyének maradványai. Megállapítottuk, hogy ez a jelenlegi temető sírjaitól keletre, a fától délre van, hajóját a sírok bolygatják. A hársfa a szájhagyománynak megfelelően a templom mellett állt. A maradványokat dokumentáltuk, a település vezetőjével és a kivitelezővel megbeszéltük, hogy a fa körülárkolásával elkerülik a templom maradványait, a támasztó betonfalat áttervezik.

\footnotetext{
12 Munkatárs: Cserép Tamás, Gál Zoltán és Nyári Zsolt.
} 
A település polgármestere - Komári József - arra kért minket, hogy lehetőség szerint tárjuk fel a szentélyrészt, a fa körülárkolásával nagyjából egy időben. A munka megvalósulása Szőkedencs község lakóinak és polgármesterének valamint a fa megóvásán is dolgozó Lukács Zoltán által vezetett Garden Kft. segítségének volt köszönhető. Míg utóbbi cég a költségeket fedezte, a település közhasznú munkásokkal valamint Komári József vezette önkéntes segítőkkel járult hozzá a feltárás sikeréhez. Mindenkinek köszönjük a segítségét.

2010. október 20. és 22. között végeztük a templom szentélyének feltárását. ${ }^{13}$ Egy téglából épült, félköríves szentélyzáródású templom részletét tártuk fel (IV. t. 6.). A szentélyrésznél az épület külső átmérője 7 méter, a belső 4,5 méter szélességű lehetett. A tájolása a nyugat-keleti iránytól délnyugat felé tér el. $A$ templom alapozását tártuk fel, a felmenő falaiból csak egy helyen maradt meg 1-2 sornyi habarcsos tégla. Az alapozás elég jól megmaradt, csak a keleti részen bolygatta néhány újkori - feltehetően a templom lerombolása utáni időszakból, az 1800-as évek elejéről származó - sír. Az alap $120 \mathrm{~cm}$ széles volt és nagyjából egy méter - 6 téglasor - mélyen maradt meg. $15 \times 30 \times 5-6 \mathrm{~cm}$ nagyságú téglákkal alapozták, a széleken egész, szabályos helyzetü, a sorok közepén töredékes, szabálytalan helyzetü téglákat használtak. A téglasorok közé agyagot döngöltek. Egy északi helyiség - talán sekrestye - indítását is sikerült megtalálnunk, ez a fa miatt sajnos nem lesz kibontható (3. ábra). A feltáráson késő középkori kerámiatöredékeket és koporsószögeket találtunk. A középkori temető két sírját bontottuk ki, ezek a fa körülárkolásakor kerültek elő. Mellékletük nem volt. 2010-ben - a még fel nem tárt területen - földradaros felméréssel próbálták tisztázni a templom alaprajzát. A felmérést az Echtelion Bt. végezte Bertók Gábor vezetésével. Ez igen látványos eredményt hozott. $A$ felmérés alapján az épület nyugati részén, négyzet alaprajzú, nagyjából 4 m-es torony helyezkedett el. Az épület a torony nélkül 10 méter külső átmérőjü lehetett.

2012-ben tervezzük a maradék épületrész feltárását, ennek megtörténte után szeretnénk egy hosszabb tanulmányban bemutatni a feltárás eredményeit. Annyit mindenesetre elmondhatunk, hogy mind építésmódjában, mind alaprajzában a térségben tipikusnak mondható, kis falusi templom viszonylag jó állapotban lévő részletét sikerült feltárnunk. ${ }^{14}$

13 A feltáráson és a szakfelügyeleten Molnár István (régész), Nyári Zsolt, Gál Zoltán, Balla Krisztián, Cserép Tamás (technikusok) vettek részt

14 A kötet szerkesztésének lezárása után - 2012 augusztusában az épület nyugati részének kibontásával folytattuk a feltárást. Ez alapján a hajó külső méretei 10,2×7,2 méteresnek adhatjuk meg. A valamivel később, de hasonló szerkezetű alapozással épült torony 2,5x4,1 méteres. Az épülethez északról egy 3,9 méter hosszú, sekrestyeként azonosítható épület csatlakozott. Ez már más szerkezettel épült - alapozását egy keményre döngölt agyagréteg felett habarcsba rakott téglák alkották. Ez az épület legfiatalabb része.

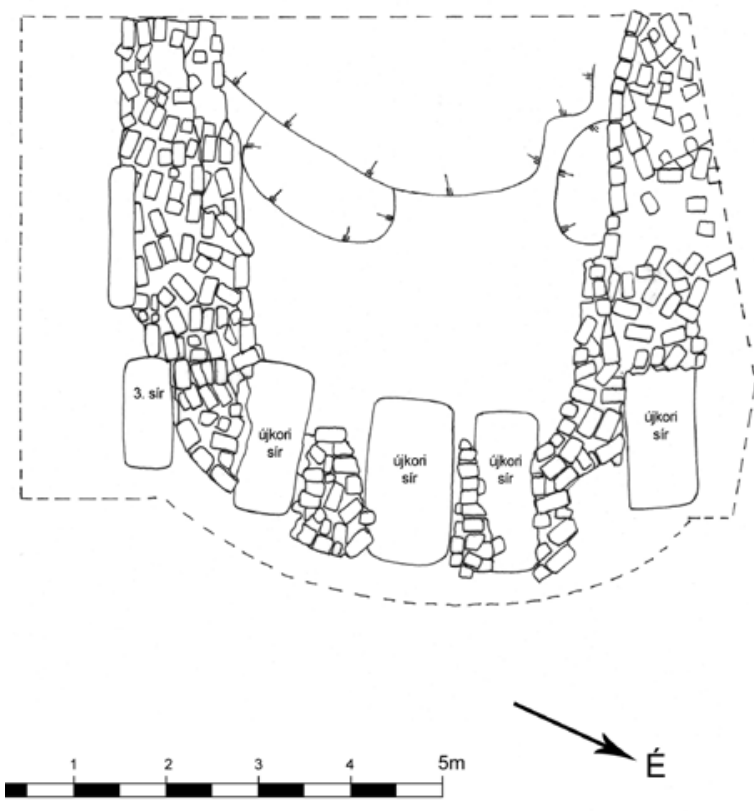

3. ábra: Szőkedencs - Temető, a feltárt templomrészlet alaprajza

\section{Iharos-Temető}

(Molnár István)

A Somogy Megyei Múzeumok Igazgatóságát az iharosi fiatalokból álló Szent László Király Lovagrend kérte fel 2009-ben hitelesítő feltárás végzésére az iharosi temetőben. Horváth Győző, a lovagrend vezetője helytörténeti kutatásai során nagy figyelmet szentelt a templomnak, összegyűjtötte a templomra vonatkozó írott forrásokat is. A települést 1268-ban királynői birtokként említik, később Kanizsai birtok. A templom első említése 1334-ben, a pápai tizedjegyzékben történik (CSÁNKI 1890. II. 613., ARADI 2007. kézirat). A török időket, ha rossz állapotban is, de túlélte a templom, felújításon is átesett. $A z$ első katonai felmérés idején még létezett, de állapota gyorsan romlott. A 19. század első harmadában elöbb a tornyát, majd az egész épületet lebontották, építőanyagát az új templomhoz használták fel. A második katonai felmérésen már nem szerepel.

2009. november 16 . és november 20 . között végeztük a hitelesítő feltárást a területen. A feltárás költségét a helyi Önkormányzat fedezte, amely közhasznú munkásokat is adott, a lovagrend tagjai közül is többen önkéntes munkájukkal segítették a feltárást. Az ásatás céljául azt tűztük ki, hogy megállapítsuk, van-e templomra utaló jel a területen illetve, hogy adatokat nyerjünk annak elhelyezkedésére, méretére. A templom feltételezett helyén két kutatóárkot húztunk. Egy kb. észak-déli irányú és egy arra meröleges, délről csatlakozó nyugat-keleti irányú árkot jelöltünk ki. Az ásatáson megállapítottuk, hogy a templom tényleg a temetőben állt, valamint nagyjából tisztáztuk helyzetét. Ekkor az első fázisban álló, Árpád-kori épület keleti végét találtuk meg. Megállapítottuk, hogy a templom 
nyugati része valószínűleg megsemmisült a működő temető sírjai miatt. Kiderült, hogy a templom jelentős méretü építmény volt, már ekkor felvetődött egy későbbi bővítés lehetősége.

2011-ben folytattuk a feltárást, ekkor az alaprajz tisztázása volt a célunk. A Somogy Megyei Múzeumok Igazgatósága 2011-ben NKA pályázaton a Miniszteri Keretből 500.000 forint vissza nem térítendő támogatást kapott. A pályázathoz az önrészt Iharos község adta. A munkák ekkor is a helyi közösséggel összefogva valósulhattak meg. Horváth Győző ekkor már polgármesterként is segítette munkánkat, több önkéntes segítő mellett az iharosberényi általános iskola diákjai is - rendhagyó történelemóra keretében - dolgoztak a feltáráson. Ezúton is szeretnénk köszönetet mondani mindenkinek, aki a két ásatási szezon valamelyikében munkájával segítette az ásatást. ${ }^{15}$

Először a 2009-es szelvényeket kötöttük össze a 4. és 5. szelvényekkel (4. ábra). Az első építési periódusban álló épület keleti végét találtuk meg. A templom első fázisa nagyméretű, vastag-falú 2,2 m széles alapozású épület volt. Egyenes záródású szentéllyel rendelkezett. 11,5 méteres külső, $7 \mathrm{~m}$ belső átmérőjü épület volt. A falusi templomokhoz képest szokatlanul nagy mérete, igen vastag alapozású fala a jelentőségére utal. A későbbi fázisban ez lehetett a templom hajója. Az alapozást téglasorok és közéjük döngölt agyagrétegek alkotják. Sajnos az alapozásból is kiszedték a téglákat, csak kevés volt a helyén, föleg az alsó 1-2 sorból. A legjobban - 7 téglasor mélyen - a keleti fal közepén maradt meg az alapozás. A szélső négy sor szabályosan volt rakva, belül kisebb, szabálytalan téglák voltak. A téglák között döngölt agyagréteg volt. 28-29×13-14×5-6 cm nagyságú téglákból épült, $5-7 \mathrm{~cm}$-es vastagságú agyagréteget döngöltek a téglasorok közé. A templom kora kérdéses. Egyenes záródása az Árpád-korra, nagy mérete - amely különlegessé teszi a korabeli falusi templomok között - a korszak végére valószínüsíti (V. t. 7.).

Mivel a 4 . és 5 . szelvényekben megtaláltuk egy újabb építési periódus nyomát, ezt követve újabb szelvényeket nyitottunk. Első lépésben a 6 . szelvényt, amely az 5. szelvény északkeleti sarkához csatlakozott, és az északi falat próbálta követni. A 2. építési periódusban a templom keleti irányú bővítése során új szentélyt kapott. Ennek 1,5-1,6 m széles alapozási árka volt, keskenyebb, mint a korábbi, de tájolása megegyezett vele. Elképzelhető, hogy a bővítés két fázisban történhetett, erre utal, hogy a korábbi faltól 6 méterre egy párhuzamos irányú, nagyjából észak-déli helyzetű fal alapárkát találtuk meg. Tehát egy keleti irányú bővítés, új szentély építése vagy az előző megnagyobbítása történt meg. Ez 10,4 m külső, 7,2 m belső átmérőjü épület lehetett. $A z$ alapozást téglasorok és közéjük döngölt agyagrétegek alkotják. A templom a második fázisában is egyenes szentélyzáródású épület lehetett. A harmadik építési periódusban egy gótikus szentély épült. Erre mutat,

15 Az SMMI részéről Molnár István, Sipos Carmen régészek, Nyári Zsolt, Cserép Tamás, Balla Krisztián, Stunya Péter technikusok, rajzolók vettek részt a munkálatokban. Külön köszönjük $M$. Aradi Csilla $(\mathrm{KÖH})$ segítségét. hogy az előbb említett keleti faltól kissé keletre, a templom északi falának külső oldalán egy $120 \times 130$ cm-es nagyságú támpillér alapozást találtunk, ezt az alapozást is téglasorok és közéjük döngölt agyagrétegek alkotják. Maga a fal alapárka azonos tájolással folytatódik. Ez az alapárok is nagyjából $160 \mathrm{~cm}$ széles, mint az előző fázisban, a téglák 29-30×6-7 cm-esek, a tapasztás 3-4 $\mathrm{cm}$-es. Ezután, amennyire módunkban állt, két kutatószelvénnyel próbáltuk követni a falat és megtalálni az épület keleti végét, megállapítani a szentélyzáródást. A korábbi keleti falaktól 11 illetve 17 méterre ferde helyzetű falat találtunk. Ez alapján talán sokszögzáródású gótikus szentélye volt az épületnek. A hozzá épített szentély így - a falusi templomokhoz képest - nagyméretü és gótikus stílusú lehetett. Természetesen megvan a lehetősége, hogy a bővítések egyszerre történtek. $A z$ átépítési idejét nem tudjuk biztosan megmondani. $A z$ egyik, az új szentélyen belül elhelyezkedő, annál valószínüleg korábbi sír földjében talált késő középkori kerámia alapján már a 15 . században történhetett.

A felmenő falakról keveset tudunk. Találtunk habarcsos téglákat, olyat is, ahol két tégladarabot fog össze habarcs, ezek feltehetően felmenő falakból származnak. Találtunk egy kisebb faragott követ, ez egykori faragvány széle is lehet.

Összefoglalva megfigyeléseinket azt mondhatjuk, hogy a templom építésmódjában tipikusnak mondható a térségben, azonban a falusi templomoknál szokatlan nagy méretei teszik különlegessé, ez különösen a korai korszakára igaz, de a később épült gótikus szentélye is nagynak mondható. Erre az írott források egyelöre nem adnak magyarázatot.

A templom körüli temetőböl 15 sírt tártunk fel, ezek estek a megnyitott szelvényekbe (V. t. 8.) A kibontott sírok többsége feltehetően a korábbi időszakból származott, az első fázisban emelt épület keleti fala mellett, a későbbi szentélyen belül voltak. Mellékletük nem volt, jellemző a medencére tett kéz.

A feltáráson igen szép leletanyag került elő, ennek legszebb részét könyvveretek alkotják. A két évben öszszesen 9 veretet találtunk. Ezekből két darab, az úgynevezett nürnbergi típusú csatgarnitúrához tartozik. Egy horgas és egy akasztós végü feliratos darab párt alkot, egy könyv oldalsó szalagjait rögzítette (V. t. 3-4.). A 15. századra, esetleg a 16. század elejére datálhatók (HoRVÁTH-Tо́тH 1993. 40.). A két veret jól összekapcsolható a 2009-ben talált 2 köldök- és 2 sarokverettel. Az egyik sarokveretnek és köldökveretnek számos párhuzama ismert, a korszak legáltalánosabban elterjedt könyvveretei közé tartoznak. Általában a 15. század második felére keltezik a hasonlókat, többször a csatot alkotó oldalsó veretekkel együtt is előfordulnak, például Decs-Etén (MıKLós-Vızı 1999. 251. 16/2, 4, 6, 7. kép), Regölyben (HAvAsSY-Vızı 2004. 230, 22. ábra), Somogyváron (BAKAY 2011. 338.) vagy a Budai könyvkötőműhely leletei között (Melis 1986. 49-50.). Egy másik sarokveretet felirata Ave Maria, Maria Mea - tesz különlegessé. (V. t. 1.). Egy szép, virágmintás díszű veret már inkább későbbi időszakra tehető. Egy gótikus, végein háromkaréjos záródású, sajnos száránál törött, kereszt (V. t. 2.) és három 


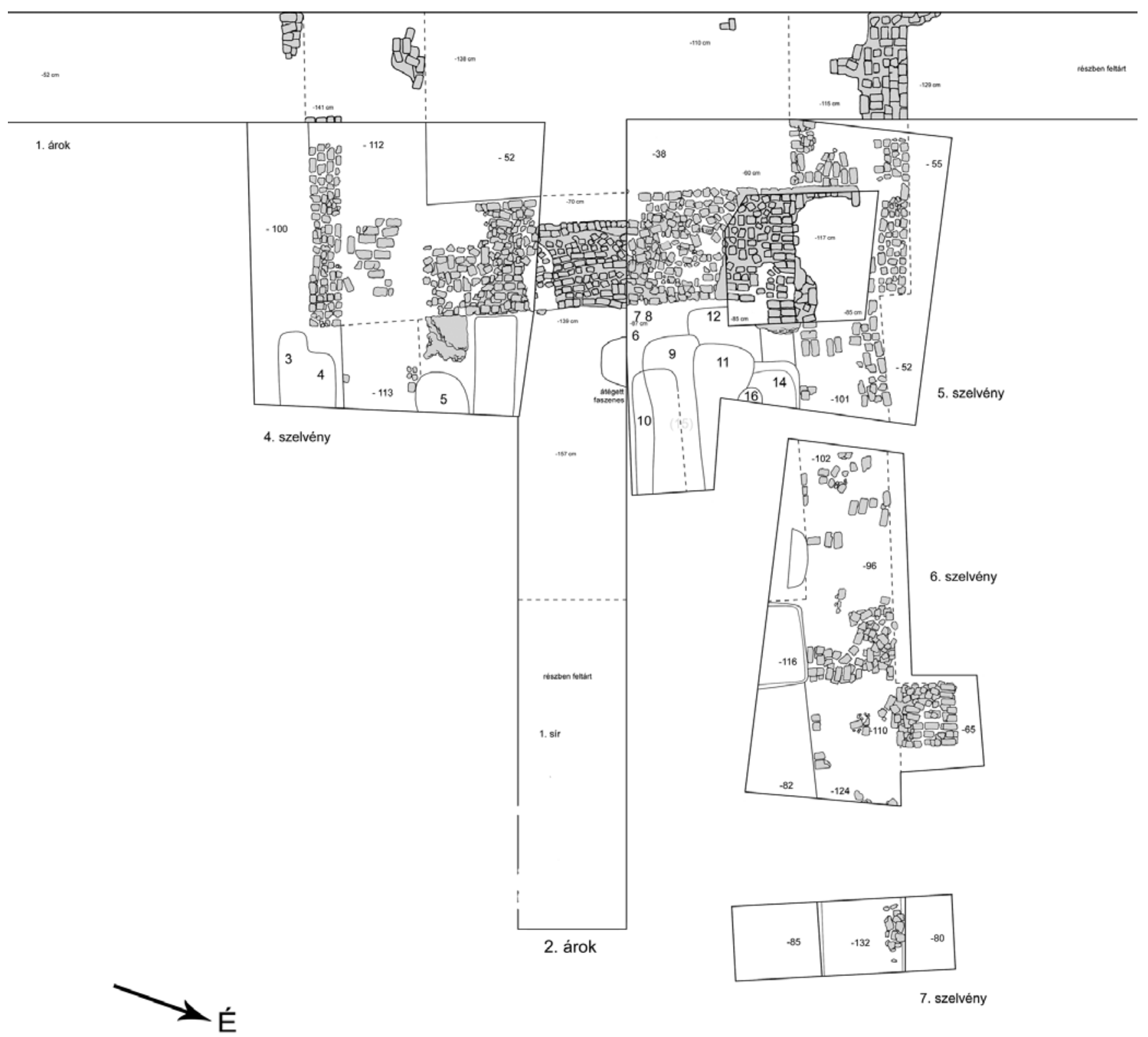

IHAROS - TEMETÖ

2009, 2011

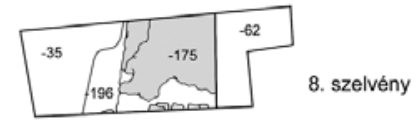


gyürü (V. t. 5-6.) is a leletanyagot gazdagítja. Az elöbbi szép párhuzama például Decs-Etéről ismert (MıKLÓs-VıZI 1999. 251, 16/8. kép), feltételezhetjük, hogy az egykori templom felszereléséhez tartozott.

A kerámiaanyag döntően késő középkori, a 13. századtól indul. Fazéktöredékeken kívül korsó-, pohár- és fedőtöredékek is előkerültek. Számos szöget találtunk, ezek nagy száma arra utal, hogy a koporsószegek mellett föleg az egykori leégett tetőszerkezethez tartozhatott a többségük. Egy zár és egy vascsat érdemel még említést.

A munkát szeretnénk folytatni. Részletesebb beszámolót majd a következő évek tervezett feltárásainak tapasztalataival kiegészítve szeretnénk készíteni ${ }^{16}$.

\section{Fonyód-Várhegy}

(Molnár István)

A Somogy Megyei Múzeumok Igazgatóságát 2009ben értesítette a fonyódi önkormányzat, hogy a Várhegyen új kilátót terveznek. Az előzetes megbeszélések során megtudtuk, hogy az építmény alapozásakor földmunkákat fognak végezni, ami előtt fel kell tárnunk az érintett területet. Mivel a tervekben szerepelt egy akadálymentesített sétány építése, valamint víz- és elektromos vezeték felvitele a sáncon keresztül, több szakaszban szakfelügyelnünk is kellett.

A vár egy szabálytalan ovális alakú központi platóból, ezt körbevevő árokból és 1-2 méter magas sáncból áll. A plató $45 \times 25$ méteres, a vár a sánccal együtt $90 \times 70$ méteres nagyságú. A Várhegyen az első régészeti kutatást Fonyód polihisztora, Bacsák György végezte 1934-ben. Sajnos a feltárás eredményeit maga nem publikálta, ezekröl részletesebb összefoglalást Magyar Kálmán közölt a „Fonyód története” című kötetben. Bacsák, aki föleg a fennsíkon és a Várhegy nyugati részén ásott, római őrtornyot feltételezett a területen, de magát a várat középkorinak tartotta. Köfalat és 20-30 cm-es gerendákból álló, agyaggal kitömött palánkfalat, a leletanyagban pedig római bélyeges téglákat, Árpádkori (9-10. századtól induló) és késő középkori kerámiát talált (MAGYAR 1985. 17-19.).

A munkákat 2009-ben a Várhegyen lévő kilátó építésével kezdték meg. ${ }^{17}$ Mivel a beavatkozás csak kisebb - nagyjából 25 négyzetméteres - területet érintett, az önkormányzattól kapott közhasznú munkásokkal megástuk a területet. A munkálatok 2009. november 11. és 13. között zajlottak. Az eredeti köves altalajt 40 $\mathrm{cm}$ mélyen találtuk meg, de számos, újkorinak bizo-

16 A kötet szerkesztésének lezárulta után - 2012. novemberében folytattuk a feltárást. A templom keleti végét kerestük, az elöző évi feltárások alapján egy sokszögzáródású gótikus szentélyzáródásra számítottunk. Ehhez képest meglepett minket, hogy egy félköríves szentélyzáródású épület keleti végét bontottuk ki, amelyet láthatólag meg is újítottak. Az épületrész jóval mélyebb alapárokban volt, alapozása habarcsos- mésszel leöntött téglákból állt. Nyilvánvaló, hogy nem egyszerre épült a 2011-ben kibontott, töle nyugatra lévő, támpilléres bővítéssel. Ettől valószínüleg fiatalabb, bár pontosabb időrendjük megállapításukban a 2011-ben nyitott 7. és 8. szelvényünk összenyitása segítene. A munkát 2013-ban szeretnénk folytatni.

17 Az ásatáson és a szakfelügyeleten részt vett: Molnár István, Sipos Carmen (régész), Nyári Zsolt, Balla, Krisztián, Cserép Tamás (technikus) nyuló beásás ennél mélyebben bolygatta a területet. $A$ plató délkeleti részén lévő, a Rákosi-korszakban épített egykori katonai légvédelmi megfigyelö-állomás lehet a pusztulás fő felelőse, de később, egy kilátó építésekor, illetve a vezetékek lehelyezésekor jelentősen megbolygatták, gyakorlatilag teljesen tönkretették a területet. $\mathrm{Az}$ árkokban talált közepes mennyiségü középkori 13-15. századi - kerámia arra utal, hogy ebben az időszakban mindenképpen lakhatták a dombot. Több tégla is előkerült a nagy mennyiségű kő mellett, ami alapján elképzelhető, hogy korábban épület állhatott valahol a területen. A feltárás során régészeti objektumot nem találtunk. Sajnos Bacsák György ásatási eredményeit nem tudtuk megerősíteni, módosítani, abban bízhatunk, hogy a plató egyes részei esetleg kevesebb bolygatást szenvedhettek.

A munka 2011 márciusában folytatódott a Várhegy déli oldalán, ekkor a vízvezetéket és a szennyvízvezetéket vitték fel a területre. Egy kisméretü $-50 \mathrm{~cm}$ széles - kanalas kotróval ásták a vezeték keskeny árkát. A földmunkát figyelemmel kísértük, időnként kézzel ráástunk, próbáltuk a sánc így kapott metszetét dokumentálni, a kidobott földet átvizsgáltuk, kerámiát kerestünk. Sajnos rendes feltárásra nem volt módunk, de úgy gondoltuk, a keskeny árokban kirajzolódó metszet is sok információt adhat az épület szerkezetéröl. Az árok átmetszésekor kisebb meglepetésünkre azt találtuk, hogy az alig töltődött fel, csak kevés humusz van rajta. Korábban sem lehetett sokkal mélyebb, viszonylag keveset is áshattak, inkább a külső sáncot építették és a domb lejtését használták ki. Esetleg a plató felőli oldalon faraghatták meredekebbre a falát. A sánc átmetszésekor a felső 30-60 $\mathrm{cm}$ humusz alatt sárgásbarna köves feltöltést találtunk, az alsó rétegek kövesebbek. Ezek a sánc alját erősítő kövek nincsenek habarccsal összefogva, vagy alaposabban megfaragva, összevissza állnak. A sánc déli, külső részénél - ahol a kiásott közmüárok igen mély volt és a sánc magassága csökken - a közmüárok alján fekete, humuszos réteg jelentkezik, ami akár az egykori felszín nyoma is lehet. Alatta néhol világosbarna réteg, talán az altalaj, látszik. Tehát - legalábbis a vár ezen részén úgy tủnik - egy lejtős hegyoldalon, azt kisebb mértékben alakítva, építették a sáncot, feltehetően igen gyorsan, a humuszra köveket és földet hordva. Sajnos a Bacsák által nagy számban dokumentált kő- és faszerkezetü falak nyomát itt sem találtuk, persze elképzelhető, hogy néhány méterrel arrébb más eredményt kaphatnánk.

A vár különböző elemeinek korát továbbra sem tudjuk pontosan meghatározni. A közműárok falából kiszedett egyik kerámia nem lehet a 13. századnál régebbi, ez alapján valamikor a 13 . században vagy azután épülhetett a sánc. Persze az ily módon nyert lelet nem igazán bizonyító erejü, későbbi bolygatás, átépítés nyoma is lehet. A sánc átvágásakor is találtunk tégladarabot, ami szintén arra utal, hogy a sánc megépülte vagy átépítése előtt is lehetett valami épület a területen. 


\section{Istvándi gázmezők és a MOL babócsai gázüzem között létesítendő gázvezeték \\ (Sipos Carmen)}

2011. június és augusztus eleje között, több szakaszban megelőző feltárásokat végeztünk az Istvándi gázmezők és a MOL Babócsa gázüzem között létesítendő gázvezeték nyomvonalán. A beruházás két korábban is ismert lelőhelyet érintett, amelyek mellé a 2010 ősze és 2011 tavasza során végzett terepbejárások során két újabbat is sikerült azonosítanunk. A feltárás során a vezeték két oldalán 3-3, összesen $6 \mathrm{~m}$ széles árkokat nyitottunk. Bár a megnyitott felületek viszonylag kicsik voltak, a feltárások elé nagy várakozással tekintettünk, hiszen egy viszonylag kevésbé kutatott, ráadásul több régészeti korszakban is a megye más részeitől eltérő sajátosságokat mutató területet érintett a beruházás.

\section{Istvándi-Csontai-dülö}

Az Istvánditól északra lévő lelőhely szántott, mezőgazdasági mủvelés alatt álló területen volt, erősen lepusztult. A nyomvonal a lelőhely keleti szélén ment végig, így mindössze egy őskori, közepes méretü, sekély gödör került elő. Az objektum a rézkori Tüzdelt barázdadíszes kerámia kultúrájához tartozott.

\section{Barcs-Somogytarnóca-Aszalói-dülő}

A somogytarnócai sertésteleptől északkeletre lévő lelöhelyet legelőnek használták. Az objektumok sürün, egymáshoz közel helyezkedtek el, maga a lelőhely le volt kopva, az objektumok viszonylag sekélyek voltak. Összesen 69 objektumot tártunk fel, többségük gödör volt, ezek mellett árkok és cölöplyukak kerültek elő. Az objektumok nagyobb része őskori. A legkorábbiak a Dunántúli vonaldíszes kerámia kultúrája időszakába tartoznak, a vékony vonalas díszítésü edénytöredékek alapján a kultúra késői időszakába keltezhetők valószínüleg. Az időrendben ezután következő Lengyeli kultúra két gödréből származó leletanyagból, a vörös festésű töredékek mellett, egy oltárhoz vagy idolhoz tartozó láb töredékét lehet kiemelni. 2 rézkori objektumot találtunk - 1-1 gödör a Tüzdelt barázdadíszes kerámia kultúrájához illetve a Bolerázi csoporthoz tartozott.

A kora bronzkori Kisapostagi kultúra 4 gödrében jellegzetesek a tekercselt pálcikával kialakított mészbetétágyas, tölcséres peremü bögrék, csuprok. Hasonló számban találtunk késő bronzkorim az Urnamezős kultúrához tartozó objektumokat. Egy kelta és két római gödör mellett 5 Árpád-kori objektum tartozott a lelőhely későbbi korszakaihoz. Az utóbbiak betöltéséből a szokásos fazékperemeken kívül agyaggolyókat is találtunk.

\section{Barcs-Somogytarnóca- Sertésteleptől ÉNy-ra}

Az előző lelőhelytől kissé nyugatra fekvő, szántott, mezőgazdasági művelés alatt álló terület erősen lepusztult. Az objektumok viszonylag sekélyek voltak. 26 objektumot tártunk fel, ezek többsége gödör volt, mellettük árkok, cölöplyukak kerültek elő. Egy kelta objektumon kívül neolit kori objektumokat tártunk fel. Legalább 6 gödör a Dunántúli vonaldíszes kerámia kultúrája idő- szakába tartozik, a kerámiatöredékeken kívül orsógombot is találtunk. Három, a Lengyeli kultúra időszakába tartozó, objektumunk volt, ezek leletanyagából kiemelnék egy festett, talpas tál töredéket.

\section{Komlósd-Mogyorós}

A Komlósdtól északra lévő lelőhelyen - két Árpádkori gödör mellett a, Dunántúli vonaldíszes kerámia kultúrája 14 sekély, kevés leletanyagot tartalmazó objektumát bontottuk ki. Ezen a lelőhelyen a terepbejáráskor összegyűjtött nagyszámú leletanyag alapján intenzív lelőhelyre számítottunk, azonban, valószínüleg a mezőgazdasági művelés miatt, egy nagyon lepusztult és az ásatáskor már ritkás lelőhely lett belőle. ${ }^{18}$

\section{Balatonendréd-Lulla összekötő út}

2010-ben kezdődtek a Balatonendréd és Lulla közötti 65137. számú új összekötő út építését megelőző régészeti munkálatok. Az akkori szabályoknak megfelelően 2010-ben a munkálatokat a Kulturális Örökségvédelmi Szakszolgálat illetve jogutódja a MNM Nemzeti örökségvédelmi Központja szervezte, intézményünk alvállalkozóként végezte a lullai szakaszon lévő feltárások szakmai munkáját. 2011-ben - a jogszabályi környezet változása miatt - a Somogy Megyei Múzeumok Igazgatósága saját jogon fejezte be a feltárásokat, emellett az útépítés földmunkáit is szakfelügyelte. Az endrédi szakasz lelőhelyeit a KÖSZ illetve a MNM-NÖK ásta ki.

\section{Lulla, Büdösalja}

Balatonendréd - Lulla összekötő út 1. lelőhely (Molnár István-Sipos Carmen)

A lelöhely Lullától nyugatra, az úgynevezett „Büdös aljában" található. A lelőhely déli része egy magas, erdős dombtetőn, középső része az eleinte meredekebb, majd lankásabb domboldalon található. Ez utóbbi részt egy földút osztja ketté. A lelőhely északi része mélyen fekvő, laposabb terület. Itt egy mesterséges medrü vízfolyás osztja két részre a lelőhelyet, a vízhez közel kissé újra emelkedik a felszín. A munka megkezdésekor, a kivitelező kívánságának megfelelően, a vízfolyástól északra lévő lelőhelyrészt tártuk fel - itt csak egy árkot találtunk. Az objektumokkal fedett terület északról jól körülhatárolható volt, egyértelmüen véget ért, határát a vízfolyás egy régebbi medre jelölte ki. 2011-ben megállapítottuk, hogy a lelöhely a dombtetőn, a korábbi erdő területén is jól lehatárolható - itt is elfogynak a régészeti objektumok.

$11251 \mathrm{~m}^{2}$-en 448 objektumot - több korszak maradványait - sikerült feltárnunk. ${ }^{19} \mathrm{~A}$ legkorábbi objektum a rézkori Balaton-Lasinja kultúra leletanyagát tartalmazta, néhány gödör kora bronzkori, a SomogyvárVinkovci kultúra időszakára keltezhető. Szép belső díszes tálak töredékei is elökerültek ezekböl az objektumokból.

18 Az ásatáson részt vett Molnár István, Sipos Carmen (régész), Balla Krisztián, Cserép Tamás, Nyári Zsolt technikus.

19 Az ásatáson részt vett: Molnár István, Sipos Carmen, Nyári Zsolt, Varga Máté, Balla Krisztián, Stunya Péter, Gál Zoltán, Cserép Tamás 
35 objektum a kelta korra tehető. A gödrök mellett egy árkot, egy épületet és egy kemencebokrot találtunk ebből a korszakból. A kemencebokor szabálytalan előtérgödréhez 3 nagyobb méretű kemence tartozott (VI. t. 9.). Hőtartó rétegként egyiknél kövek, a másiknál egy tál töredékei voltak a platni alatt. $\mathrm{Az}$ épület téglalap alaprajzú, tüzelöberendezése nem volt. A korszak jellegzetes edénytöredékei mellett szövőszéknehezék, orsókarikák, egy öntőminta töredéke, vaskés is előkerültek a kelta objektumokból. 8 római objektum is volt a lelőhelyen, két, viszonylag sekély, nagyobb méretű objektum, talán épületmaradvány mellett 2 árok és 4 gödör.

$\mathrm{Az}$ objektumok többsége a kora Árpád-kortól a késő középkorig terjedő időszakból származik. Nagyobbrészt a középkori Lulla maradványait tártuk fel. Megállapítható, hogy a késő Árpád-korban inkább a magasabban lévő domboldalt lakták, míg a korai Árpád-korban (hasonlóan a kelta és római időszakhoz) több objektum volt a mélyebben fekvő részeken. Az objektumok viszonylag sürün helyezkedtek el, többször metszették egymást. A számos gödör, cölöplyuk, árok mellett több külső kemence és kemencebokor is feltárásra került (VI. t. 8.). 15 kemencét biztosan, néhány másikat feltételesen a korszakra datálhatunk. Hőtartó rétegként kerámiát illetve köveket találtunk a platnik alatt. A lelöhely egyik legérdekesebb objektuma egy kora újkori téglaégető kemence (VI. t. 10.), amelynek sajnos csak a legalsó része maradt meg. A maradványaiban közel 5,5 m hosszú, négyzethez közelítő téglalap alaprajzú objektumnak három, $40 \mathrm{~cm}$ széles tüzelöcsatornája volt. Egy földbemélyített alapárkos épület - talán veremól vagy pince - is kibontásra került (VI. t. 11.). A domboldal nagy lepusztultságát figyelembe véve az építményt eredetileg erősen a földbe mély földbe mélyítették. Több objektum is rombolja, amennyire megítélhető nagyjából $8 \mathrm{~m}$ hosszú és 4,8 m széles lehetett. Hosszanti fala mellett egy alapárokban, a rövid oldalon magukban állnak az oszlopsorok, de a tetőszerkezetét a középvonalában lévő igen nagy méretü és mély oszloplyukakban álló ágasfák tarthatták. Bejáratát - a későbbi bolygatások miatt - nem találtuk meg, talán a délkeleti rövid oldalon lehetett. Az északnyugati rövid oldalában lévő külső kemencét később vájhatták a felhagyott épület oldalába. Az épület igen hasonlít az Ordacsehi-Bugaszegen talált veremólakhoz (NAGYGALLINA-MOLNÁR-SKRIBA 2001). Lakóházat nem találtunk, ami a lelőhely felső rétegének erős pusztulásával magyarázható. Egy nagyobb területet bezáró, ovális alakú kerítőárok és egy kút emelhető ki a középkori objektumok közül. Az objektumok gazdag leletanyagot tartalmaztak. A nagyszámú kerámia (köztük cserépmécses VI. t. 7.) mellett több vaseszköz - közte több kulcs és olló, számos kés és szög, valamint sarló, szőlőmetsző-kés, vakaró, sarkantyú került felszínre az objektumokból (VI. t. 1-6.)

\section{Lulla-Jabapuszta DK}

Balatonendréd - Lulla összekötő út 3. lelöhely

(Hajuú Ádám Dávid)

A lelőhelyen a Somogy Megyei Múzeumok Igazgatósága 2010. október-november, majd 2011. augusztus-október között folytatott régészeti feltárást. ${ }^{20} \mathrm{~A}$ kijelölt terület Lulla-Jabapuszta településtől DK-re, a Jaba-patak keleti oldalán, a két települést összekötő korábbi mellékút alatt és annak két oldalán helyezkedik el, a Szilfás dülő területén. A Jaba-patak - miután elhagyja Lulla települést ÉK-nek fordul, és egy ugyanilyen tájolású völgyben halad tovább egészen Jabapusztáig, melynek északi határán fordul nyugatnak. A patakvölgy Jabapuszta elött kissé kiszélesedik, nyugati oldala erősebben, míg keleti oldala lankásabban lejt, ezen az oldalon találjuk lelöhelyünket.

A munkálatokat egy viszonylag kis területen 2010. öszén lehetett megkezdeni, majd a 2011-es év augusztus-október közötti időszakában került sor a még megmaradt rész régészeti feltárására. $A$ két évad során közel $10000 \mathrm{~m}^{2}$ nagyságú területet sikerült átkutatni. Öszszesen 232 különböző objektum került elő, nagyobb sűrüségben a terület északi és középső részén, az utóbb kijelölt déli részen viszonylag lazább szerkezetben. ${ }^{21}$ Mindezek alapján feltételezhető, hogy a patak keleti oldalán a lelőhely egészen a szomszédos Lulla település északi széléig tarthatott, így lényegesen nagyobb területre terjedt ki, mint azt az előzetes terepbejárás mutatta. Az ásatási munkálatokat nehezítette, hogy a meglévő út alatti területet - mivel ezen csak burkolatcsere történt nem volt lehetőség feltárni. A keskeny szelvények miatt az objektumoknak gyakran csak részletei voltak feltárhatóak, több, régészeti szempontból értékes jelenség az útpadka alá is benyúlt, így azok kutatása csak részben volt lehetséges. Fontos még megemlíteni, hogy az út közelsége miatt igen sok újkori árok került elő. Ezek több esetben megbolygatták és részben elpusztították az ott található régészeti objektumokat.

Az összesen felszínre jött 232 objektum több különböző típusba sorolható. Legnagyobb számban a különböző méretű és funkciójú gödrök, vermek és cölöplyukak ismertek, de feltárásra került még 15 téglalap alaprajzú, félig földbemélyített ház, 2 edényégető kemence és 3 - feltehetöleg háztartási célra használt, sütő/főző funkcióval bíró - földbevájt kemence is. Mindezek a jelenségek egy laza szerkezetü, viszonylag nagy területü telep/falu részét képezték. A jelenségek zöme, a belőlük előkerült leletanyag alapján a római kor első felére, a Kr.u. 1-3. század közötti időszakra tehető. Az egyes objektumok közül külön érdemes kiemelni az elökerült házakat, illetve a kemencéket.

20 KÖH lelőhely azonosító: 46995. Az ásatáson részt vettek: Régészek: Sipos Carmen, Molnár István, Hajdú Ádám Dávid. Munkatársak: Bajzik Annamária, Balla Krisztián, Cserép Tamás, Gál Zoltán, Máté Dóra, Nyári Zsolt, Stunya Péter, Varga Máté. Külön szeretnék köszönetet mondani Dr. Honti Szilviának, a SMMI régész osztályvezetőjének.

21 A területet igen vastag $(100-150 \mathrm{~cm})$ humuszréteg fedte, amely már a terepbejárás során akadályozta a lelőhely pontos határainak a meghatározását. Ezen okból, a feltárással párhuzamosan folyó és a régészeti lelőhelyet még érintő földmunkákat folyamatosan megfigyeltük és az itt elökerülö objektumokat részben, vagy teljesen feltártuk és ledokumentáltuk. 
Az általában téglalap formájú, félig földbemélyített, a tetőszerkezetet ágasfával alátámasztó gödörház/veremház az egyik legismertebb jelenség típus nemcsak Somogy megye (NÉMETH 2007a, 35-40., NÉMETH 2007b, 41-46.) és Pannonia tartomány, de a Római Birodalom más területén és annak határain túl is. ${ }^{22} \mathrm{~A}$ lelöhelyen általunk feltárt házak négy csoportba sorolhatók be. A legáltalánosabb és lelőhelyünkről a legnagyobb számban felszínre került háztípust a téglalap formájú, két rövidebb oldalán középen elhelyezett, egy-egy oszloplyukkal rendelkező szerkezet jelentette (VII. t. 3-4.). Ennek lehetett feltételezhetőleg egy variációja, amikor a két rövidebb oldal mentén elhelyezett oszlopok mellett, azokkal egy vonalban, de a ház közepén egy további oszlophelyet alakítottak ki. Ezen két típustól jelentősen eltért a 89. és 200. objektumoknál megfigyelt szerkezet. A 200-as objektum esetén ugyanis a rövidebb oldalak mentén nem egy-egy cölöplyuk volt, hanem közvetlen egymás mellett, jól elkülöníthető módon kettő-kettő (VII. t. 6.). Az oszlopok ilyen jellegü elrendezése feltételezhetőleg a ház eltérő funkciójából fakadhatott. Szintén különbözött a lelőhelyünkön megfigyelt általános típustól a 89-es objektum szerkezete. Itt a tetőszerkezet fő megtámasztására a két rövidebb oldal mentén kialakítottak egy-egy igen nagy átmérőjű és mély cölöplyukat, azonban a ház nagysága és a feltárás során megfigyelt egyéb sajátosságok miatt ezt kiegészíthették a két hosszabbik oldal mentén további kisebb cölöplyukakkal (VII. t. 5.). A cölöpszerkezetnél megfigyelt különbségek ellenére a házak igen sok hasonlóságot mutattak. Mindegyikük téglalap formájú, kelet-nyugati tájolású, földbemélyített volt és területük 20-30 m² között váltakozott. ${ }^{23}$ Minden esetben megfigyelhető volt a tapasztott padló valamilyen formája. Tüzelőberendezés nyomát mindössze két esetben sikerült $(89,200$. objektum) dokumentálni. A tetőzet anyagára-szerkezetére vonatkozólag jelenség vagy leletanyag nem került elő. A falazatra vonatkozólag is mindössze a 89-es objektum szolgált információval. A gödörház szélei mentén előkerült veszsző, illetve deszkalenyomatos patics maradványok a ház felmenő falazatára utalhatnak.

$A z$ előkerült kemencék két csoportba sorolhatók. Az egyik csoportot a kerek, földbevájt, egyrétegü platnival rendelkező kemence típus $(4,70,72,148,167$. objektumok) jelentette, melyekhez földbevájt elötér gödör csatlakozott. A platni bontása során hőtartó rétegként kavicsot vagy kerámiát találtunk. A kutatás jelenlegi állása szerint ezek az ún. külső kemencék feltételezhetőleg sütő/főző funkcióval bírhattak. A másik csoporthoz az edényégető kemencék sorolhatók (8, 198. objektum). Az általunk feltárt két objektum kerek alaprajzú volt, tüzelőterüket egy

22 A veremházakra vonatkozó szakirodalom: Pannonia esetében lásd: Bóna 1988, 401-414., Budal Balogh 2009, 77-110., Cencic 2004, 9-116., Gabler 1980/81, 71-101., GableR 1982, 57-127., HoRVÁTH 1987, 59-81., KOCZTUR 1972, 43-57., OTTOMÁNYI 2005, 67-132., OtTOMÁNYI 2007, 7-239., PeSt 2007, 249-325., SzÖNYI 1996, 249256., Barbaricumra vonatkozólag lásd: DinNYÉs 1997, 367-373., Donat 1998, 1-50., DroberJar 1997., Pest 2007, 351-377., Leube 1992, 130-146.

23 Ez alól egyetlen kivétel említhető a 89-es objektum, melynek mind mérete $\left(40 \mathrm{~m}^{2}\right)$, mind szerkezete jelentősen eltért a többi feltárt házétól. tartóborda osztotta ketté, rostélyukon pedig 3 koncentrikus körben helyezkedtek el a lyukak (VII. t. 1-2.). A tüzelőtér földbevájt oldalfala vastagon átégett, de tapasztás nyomait nem észleltük. Az égetőtér alsó részét szintén földbevájták, felmenő falait betapasztották, és a metszetre bontás során megfigyelhető volt az oldalfal fokozatos összeszükülése, amely alapján feltételezhető, hogy a kemence kupolája félgömb formájú lehetett.

A római korra datálható objektumok mellett még feltárásra került egy kora bronzkori - a SomogyvárVinkovci kultúra időszakára tehető - gödör és egy későbbi, feltehetően a középkori vagy az újkori országút mellett futó árok is.

A feltárt objektumok igen gazdag leletanyagot tartalmaztak. A fém leletek közül kiemelhető a közel 50 darab ezüst és bronz pénzérme, illetve a különböző formájú bronz fibulák, így omega-, aláhajtott lábú-, T-formájúés hagymafejes fibulák. A vastárgyak közül a viselethez tartoztak a változatos formájú övveretek, a használati eszközök közé a sokféle szerszám, például véső, kés, vagy a nyílhegy. Ezen felül vas ekepapucsot találtunk egy épület, valamint vas csoroszlyát egy tárolóverem betöltésében. A római import áruk, így a terra sigillata és az üvegleletek kis számban ugyan, de lelőhelyünkröl is ismertek, illetve fontos említést tenni még az egyik gödörház betöltéséből előkerült kék színü üveggyürü töredékröl is. Azonban az elöbb felsorolt import áruk és fémleletek száma eltörpül a leletanyag legnagyobb hányadát kitevő kerámiaanyag mellett, melyek között a jellegzetes római kori szürke házikerámia különböző típusai kerültek elő. Ezeken kívül sok objektumból tipikus késő-kelta kerámia (pl.: grafitos kerámia, besimított edények, „S” profilú tálak, behúzott peremü tálak) és az ún. kézzel formált bennszülött kerámia (pl.: fazekak, tálak, fedők és az ún. dák csésze) is előkerült.

A feltárt jelenségek döntő része, a belölük elökerült leletanyag alapján a római korra, a Kr.u. 1-3. század közötti időszakra tehető, de a feltárás során előkerült hagymafejes fibulák és késő-római érmek alapján feltételezhető, hogy a telep bizonyos része egészen a Kr.u. 4. századig létezhetett. Az utóbbi évek során Somogy megye Balatonhoz közelebb eső régiójában elvégzett megelőző régészeti munkák mind azt bizonyították, hogy a megye ezen részén viszonylag sürü településhálózat létezett a késő kelta korban, mely falvak, nyílt színi telepek egy részének zavartalan továbbélése a római hódítás után is kimutatható. Ebbe a képbe igen jól illeszkedik a Lulla-Jabapuszta mellett feltárt telep, mely így újabb adalékkal szolgál Somogy megye késő-kelta és római kori történetéhez.

\section{Lulla, Jabapuszta - Jóreménység TSz}

Balatonendréd - Lulla összekötő út 4. lelőhely

(Sipos Carmen)

A lelőhely a Lullához tartozó Jabapuszta mellett, attól északra, található, az egykori országutat (földutat) és annak két oldalán lévő területet érinti. A Jaba-pataktól nyugatra lévő domb - a Jaba-hát - keleti oldalán lévő lelőhelyen jelentős szintkülönbségek voltak, keletre a patak felé erősen lejtett a terület. 
A lelőhelyet 2011. augusztus 15. és szeptember 30. között tártuk fel - egy késő rézkori és egy kora bronzkori - a Baden kultúra illetve a Somogyvár-Vinkovci kultúra időszakába tartozó - település maradványait találtuk meg. ${ }^{24}$

$\mathrm{Az}$ objektumok nagyobb része késő rézkori volt. A terület déli részét egy hatalmas méretü - a szelvénybe kb. 85 méter hosszan 9,5 méter szélességben benyúló - gödörkomplexum foglalta el (VIII. t. 5.). Ez több objektumot metszett, felülrétegzett, számos - mind rézkori, mind bronzkori - objektumot pedig ebbe ástak bele. Ezen a nagyméretű objektumon kívül számos kisebb-nagyobb gödör és 6 tüzelöberendezés került elő a Baden kultúra időszakából. A kemencékből általában csak a platni vagy annak egy része maradt meg, mindössze egy kemencénél voltak meg a palást maradványai $\mathrm{kb} .30 \mathrm{~cm}$ magasan. A platni alatt több esetben hőtartó kerámiaréteggel volt kirakva a kemence.

A kultúrára jellemző állattemetkezésekre is számos példát találtunk. 4 szarvasmarha-temetkezés fordult elő (VIII. t. 2., 6.). Ezeket az állatokat sekély, ovális gödrökben, két esetben edény-melléklettel temették el (az egyik esetben a váz mellett egy kétosztatú tál töredékei voltak). Az állatok tájolása eltérő, általában behajították őket a gödörbe. A szarvasmarha temetkezéseken túl egy mély gödörben egy jobb oldalára fektetett fiatal szarvas maradványai feküdtek (VIII. t. 1.), egy másik objektumban két állat - talán vadmalac és vadmacska - volt eltemetve. A jobb oldalukon feküdtek tájolásuk kelet-nyugati, a szarvaséval ellentétes volt. Ez utóbbi gödörből egy emberi láb csontjai is előkerültek.

Az emberi temetkezésekre (áldozati helyekre?) példa egy szintén hiányos sír: egy gödör alján anatómiai rendben talált lábcsontok voltak (VIII. t. 3.). A hiányos csontvázak mellett elökerült még egy csoportos temetkezés is - két felnőtt, és két kisgyermek (ebből az egyik csecsemő ill. magzat) csontváza - ezek azonban szintén nem szabályos temetkezésként, hanem csak a gödörbe, rendezetlenül egymásra dobált holttestekként értelmezhetőek (VIII. t. 4.). Az egyik felnőtt kezei szorosan egymás mellett voltak - talán összeköthették őket. $A$ vázak szintjén és alattuk égett réteg volt megfigyelhető a gödörben.

A lelöhely igen gazdag volt leletekben, hatalmas mennyiségű kerámia, közte számos kétosztatú-tál és merice töredéke került felszínre.

A bronzkorból a Somogyvár-Vinkovci kultúra számos gödre került elő a lelőhelyröl. Ezek is gazdag leletanyagot tartalmaztak. Több belsődíszes tál, egész és töredékes orsógombok, hengeres agyagnehezékek kerültek kibontásra az időszakból.

A lelőhely keleten és nyugaton a nyomvonalon kívül biztosan folytatódik. Az északi vége lezártnak tűnik, délen azonban szintén folytatódhat a lelöhely.

$24 \mathrm{Az}$ ásatáson részt vett Molnár István, Sipos Carmen, Hajdú Ádám Dávid régész, Balla Krisztián, Cserép Tamás, Gál Zoltán, Nyári Zsolt, Stunya Péter, Varga Máté technikus.

\section{Kaposvár-Kertészet, Ezüsthárs lakótelep \\ (Költő László)}

A lelőhely az 1970 -es évek óta ismert. ${ }^{25}$ őskori településjelenségeitől északra az úgynevezett „Ezüsthárs” lakótelep telekkialakítása, közművesítése során előkerült Árpád-kori temető közművek által bolygatott területének feltárását 2005-ben végeztük el, melynek eredményéröl a Somogyi Múzeumok Közleményei 18. kötetében számoltunk be (KöLtö-BAJzıK, 2008).

Későbbiekben számítani lehetett rá, hogy a kialakított építési telkek beépítésének kezdetekor a fel nem tárt temetőrész feltárására is szükség lesz. Erre 2010-ben, illetve 2011-12-ben került sor. 2010-ben a $6268 / 11$. és 26 . helyrajzi számú telkeken, 2011-12-ben a 6268/12. helyrajzi számú telken folytattunk feltárást. Ezzel sikerült meghatároznunk a temető DNy-i és ÉK-i sarkát, valamint az É-D-i kiterjedését (5. ábra).

$\mathrm{Az}$ építési telkek alatti temetőrész feltárása során további 209 sír, így eddig összesen 341 sír került elő. Köztük három kettős sír (279., 434., 425.), és két meghatározhatatlan korú állat (kutya)-temetkezés volt. Az újabban feltárt sírok közül 78 volt melléklet nélküli, tehát összesen 152 sír.

A 6268/12. helyrajzi számú telken, az Árpád-kori temető K-i széle alatt egy késő avar kori temető sírjait találtuk meg. Az eddig feltárt 341 sírból 26 bizonyult avar korinak. Az avar temető elhelyezkedésének érdekessége, hogy a két temető „találkozásánál”, bár az avar sírok egyértelmüen mélyebbek, és az Árpád-koriak alatt foglalnak helyet, tájolásuk beleilleszkedik az Árpád-kori sírok $\mathrm{K}-\mathrm{Ny}$-i tájolási rendjébe, $\mathrm{K}$ felé haladva fokozatosan „fordulnak el” ÉNy-DK irányba.

Az Árpád-kori temető leleteinek legtöbbje a később feltárt részben is az általános, a korra jellemző típusok, „S” végű karikák, huzal fülbevalók, gyürük. Némelyik sírban több gyűrüt is találtunk, gyakori volt a 2 gyürü viselése. Ebben a temetőrészben több volt az ezüstből készült tárgy („S” végü karikák, gyürük). Ezeken kívül több archaikus vonás is jelentkezett (csüngős ingnyak veretek, stilizált állatfejes bronz karperec). Összesen négy újabb érmét találtunk, Szt. István és I. András ezüst dénárjait. A 252. sz. sírban sodrott nyakperec, stilizált állatfejes karperec, gyürü és „S” végü karika mellett $5 \mathrm{db}$ ónozott bronzból készült csüngős, és egy db csüngő nélküli ingnyak veret került elő. (IX. t. 8.) Hasonló díszeket találtunk a 329. és a 418. sz. (IX. t. 4.) sírban (elöbbiben a koponya jobb oldalán egy nyílcsúcs is volt). A 379. sz. sírban csüngős ingnyak-veret csüngő tagja volt ezüst fóliás hordó alakú gyöngyökkel nyakláncban. A 381. sz. sírban kis méretű vastag „S” végű karikákból (9 db) álló fejék volt, fóliás gyöngyökből álló nyaklánc kíséretében. Szokatlan összeállítású a 334. sz. sírban talált, 5 db lunulából, 2 db bronz csörgőből és ezüstfóliás apró gyöngyökböl összeállított nyakék. (IX. t. 7.) A 287. sz. sírban egy-egy pár arany, és aranyozott ezüst „S” végű karikát, ezüst gyűrüt, és egy rossz megtartású, egyelöre meghatározhatatlan, kisméretü, ezüst pénzérmét találtunk.

25 BÁRdos E. 1978: SMMI Régészeti Adattár IV/1/980/b.; EcsEdY I. 1972, 1973: SMMI Régészeti Adattár IV/1/260/b; IV/1/260/a; HORVÁTH L. HROTKó Zs. - KLING J. 1974: SMMI Régészeti Adattár IV/1/317/a. 


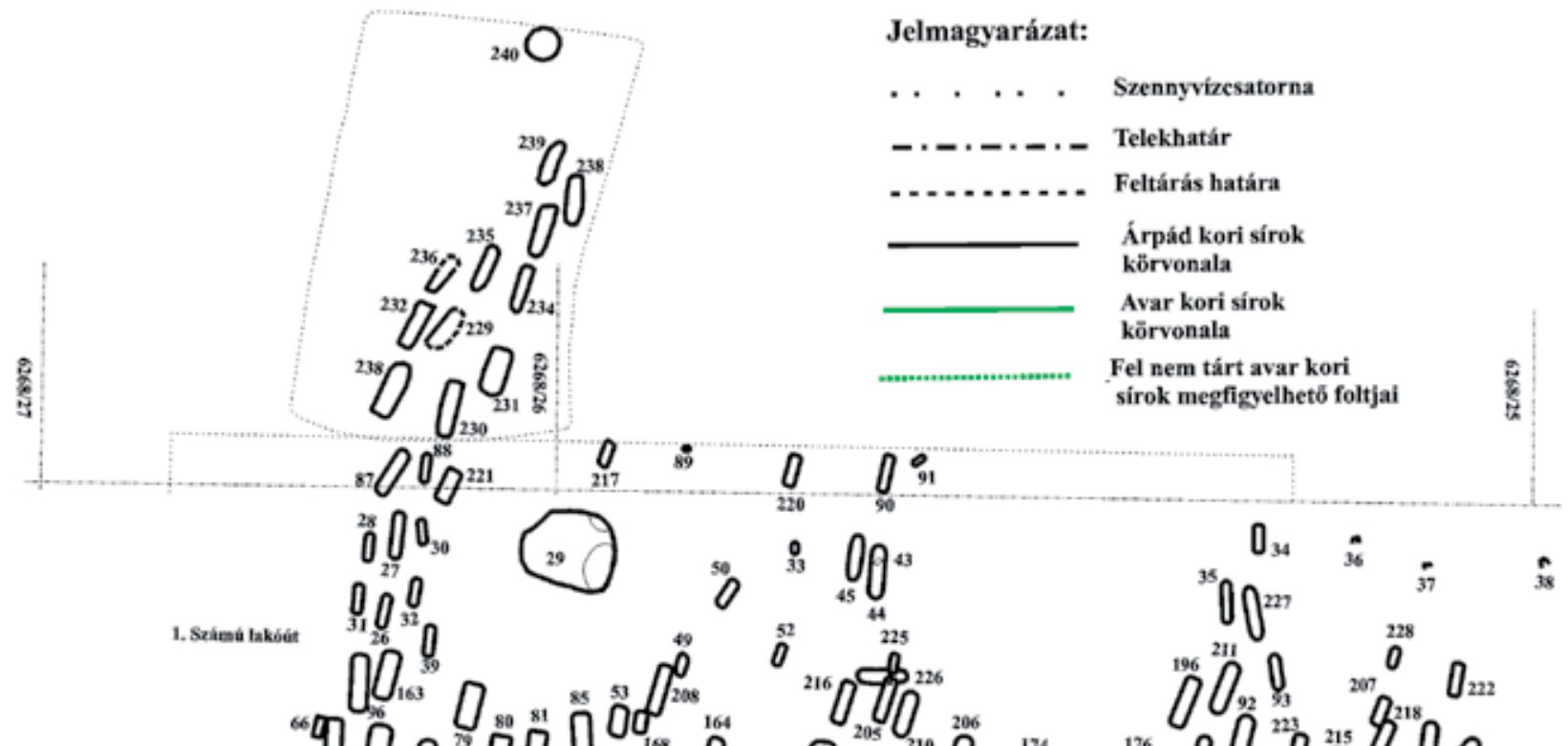

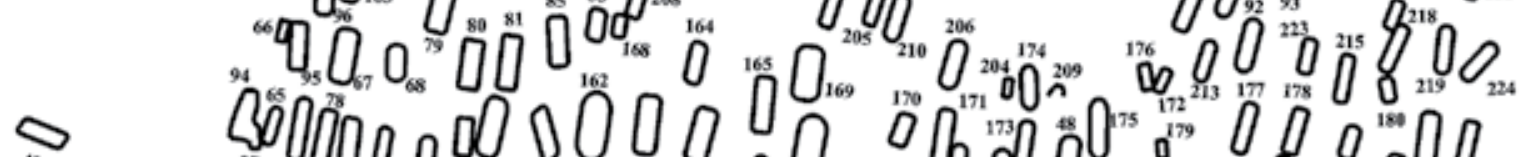

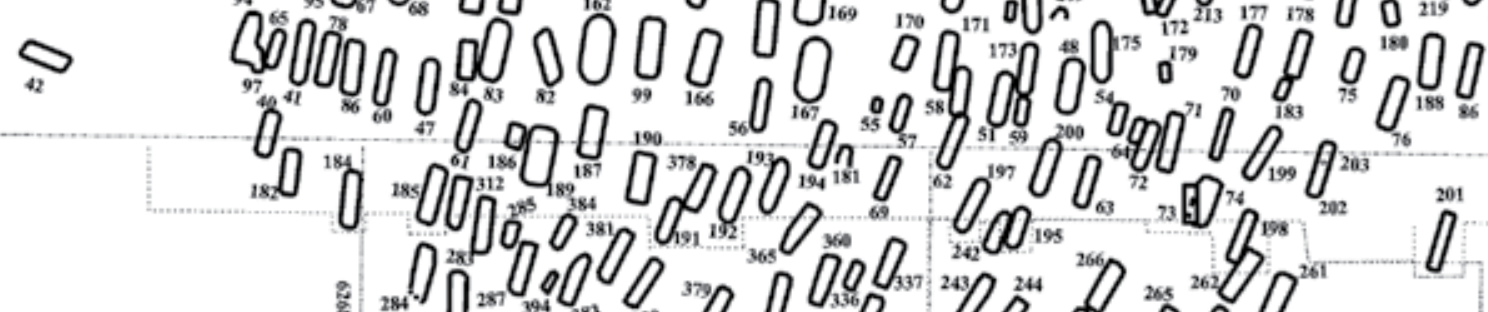

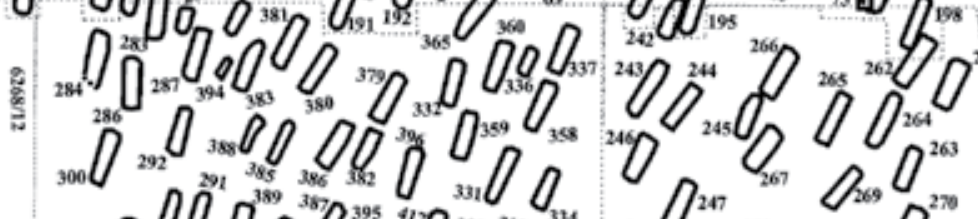

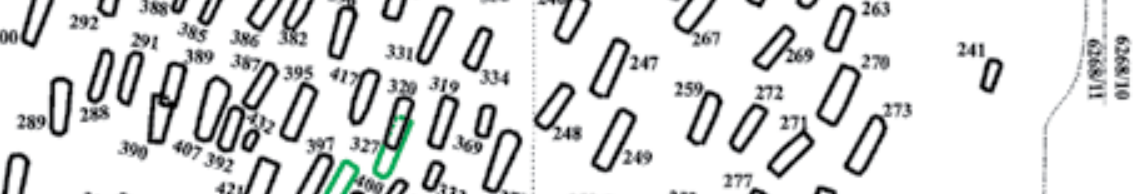

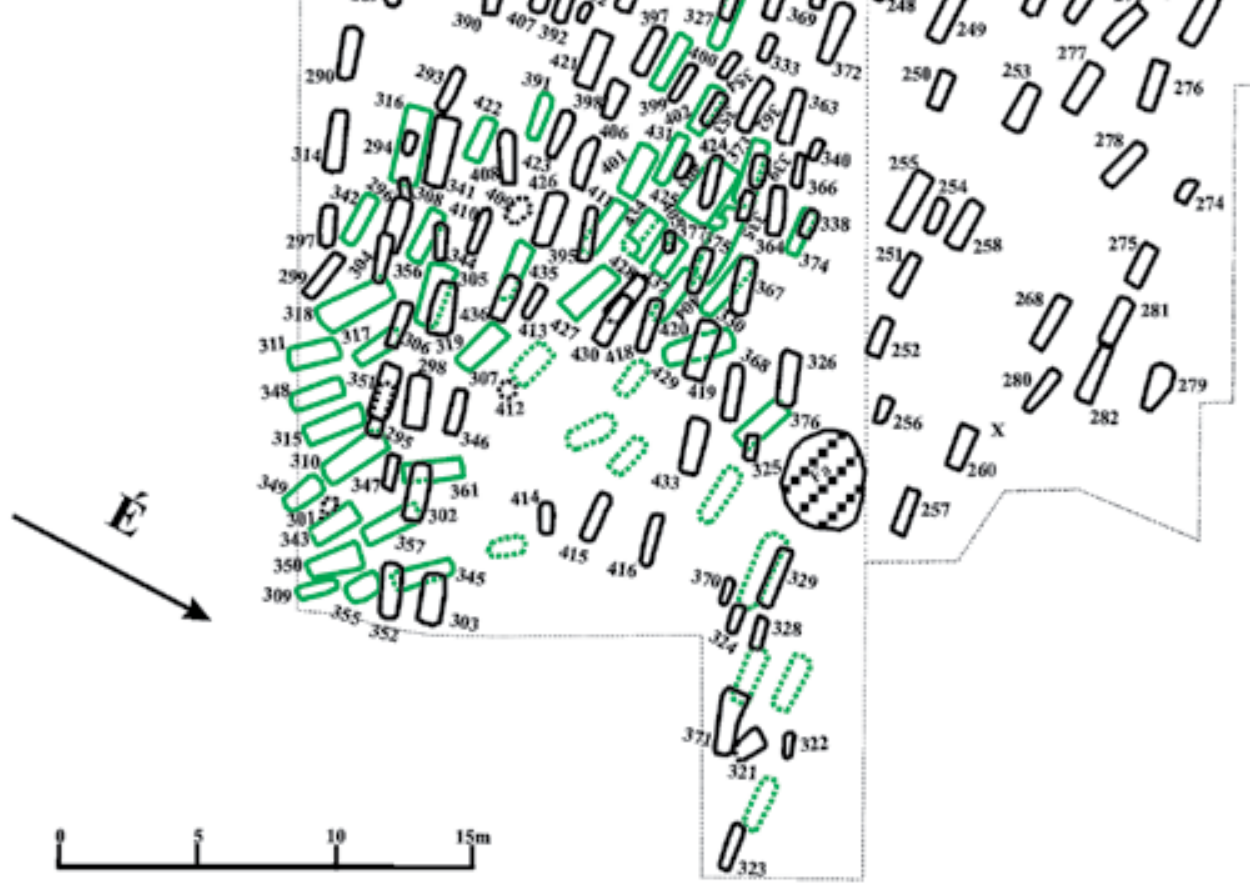

5. ábra: Kaposvár-Kertészet, Ezüsthárs lakótelep, a temetö összesitő térképe 
A sírok viszonylag sekélyen feküdtek, a vázakat a korábbi talajmüvelés erősen roncsolta, valamint az egyébként is agyagos, agresszív talajba juttatott vegyszerek hatása következtében a csontok jelentős része felszívódott. Koporsó nyomait továbbra sem lehetett megfigyelni, néhány esetben viszont a csontváz helyzete arra utalt, hogy az elhunytat valamibe betekerve helyezhették sírba. A vázak háton fekvő, nyújtott helyzetüek voltak, egy-egy esetben figyelhettünk meg kissé zsugorított helyzetü (jobb oldalára történt), valamint ún. „béka” helyzetű fektetést (IX. t. 3.). Az alkarokat általában könyökben különböző mértékben behajlították, néhány esetben mindkét kar a vállhoz, illetve a mellkason keresztben az áll alá volt behajlítva.

Az avar kori sírok jellemző leletei az ovális karikájú, lengő csüngős fülbevalók, esztergált csont, illetve vas csőböl készült tütartók, poncolt díszü bronz karperecek, dinnyemag alakú, és többtagú rúdgyöngyök, öntött veretes övgarnitúrák. Ez utóbbiak között különleges, vidékünkön szokatlan formájú csüngővel szerelt veretek is előfordultak (345. sz. sír, IX. t. 6.). A veretes sírokat az Árpád-kori temetőtől távolabb eső területen, a 6268/12 hrsz-ú telek keleti vége felé találtuk. Az Árpád kori temetővel érintkező részen csupán a nőket temették felékszerezve, gazdag mellékletekkel, a férfi sírok általában melléklet nélküliek voltak, illetve egy-egy vas kés fordult elö bennük. A nők sírjában több esetben fordult elő mellékletként tojás (307., 349., 429. sz. sír, IX. t. 1.).

Érdekes a gyöngycsüngős és az „S” végü fülbevalók együttes előfordulása. A 429. sz. sírban egymásba füzve került elő mindkét fülben egy-egy „S”végű és gyöngycsüngős fülbevaló-pár, a 437. sírban spirálcsüngős fülbevaló volt „S” végü karikával együtt. A 402. sz. sírban szokatlanul nagy méretü, hólyagos többtagú gyöngyök voltak (IX. t. 2.).

A 305. sz. sírban a váz jobb térde mellett bronz pántos fa vödröcske maradványait találtuk. Az avar kori temetkezések minden esetben koporsósak, a sírok mindkét vége lemélyített, 1-2 esetben sírépítmény megléte valószínüsíthető (a sírgödör sarkaiban, illetve oldalában cölöpnyomok - 355. sz. sír, IX. t. 5.). A koporsók általában ácsoltak voltak, egy esetben találtunk koporsóvasalásokat (374. sz. sír). Ez utóbbi sír formája eddig párhuzam nélkül áll, „álpadmalyosnak” neveztem el, ugyanis a sírgödör mindkét hosszanti oldalában (a bal oldaliban szélesebb) padmalyt alakítottak ki, azonban annak mérete nem volt elegendő a koporsó befogadására, a koporsót a fő aknában helyezték el.

A temető feltárását a 6268/12 hrsz-ú telken anyagi lehetőségek hiányában kénytelenek voltunk úgy végezni, hogy a magasan fekvő Árpád-kori temetőrészt teljes egészében feltártuk ugyan, de a mély avar kori sírok közül csupán azokat tártuk fel, amelyek várhatóan az épülő ház alá kerülnek, és ezáltal megsemmisülnének, illetve a későbbi kutatás számára elérhetetlenné válnának.

Az Árpád kori temetőt archaikus vonásai, a benne előkerült leletek alapján Kaposvár közigazgatási területén előkerült legrégibb ilyen korú temetőnek tarthatjuk.

\section{Örtilos/Belezna - Zrínyi-Újvár \\ (Költő László)}

Zrínyi-Újvár maradványai Somogy és Zala megye (Örtilos és Belezna községek) határán, egy, a Murával párhuzamos dombhát, az őrtilosi Szent Mihály hegy északi végén találhatóak (X. t. 2.).

A vár pontos helyével kapcsolatban csaknem egy évszázados vita alakult ki a történeti szakirodalomban, mivel az 1661-ben felépült palánkvárat az 1664-es ostrom után a törökök teljesen lerombolták és az később sem épült újjá. Amikor az utókor figyelme ismét a vár felé irányult, annak maradványai már nem voltak beazonosíthatók, az egykorú metszetek némelyike pedig egyenesen félrevezető volt. Többen voltak, akik a mai Horvátországba, a Mura jobb partjára helyezték. A magyar történészek a bal parton, az őrtilosi Szent Mihály-hegyen vélték megtalálni a várat. Az elörelépést egy Esterházy Pál hagyatékából előkerült hadmérnöki vázlat jelentette. Ez alapján Hrenkó Pál térképtörténész beazonosította a vár feltételezett helyét (HRENKó 1979), amelyet Vándor László korábbi helyszíni kutatásai során talált késő-középkori cserepek alapján szintén erre a helyre feltételezett (VÁNDOR 1972. 498-912).

Vándor László az 1994-ben megjelent Nagykanizsa monográfiájának első kötetében már több mint két évtizedes kutatása eredményei alapján írhatta le: „Zrínyi-Újvár stratégiailag igen jól kiválasztott ponton, a Mura és a Dráva összefolyásának közelében, a ma Beleznához tartozó Kakonyapuszta (korábban Kakonya nevü falu) fölé magasodó, a Mura folyóval párhuzamos hegyhát végén épült fel. $A$ vár védelmét természeti körülmények is segítették, itt torkollott a Murába a Kanizsa folyó, és a hegyhát védelmét erősítette az ún. Visszafolyó-patak mocsaras völgye is..." (VÁNDOR 1994. 371) ${ }^{26}$

A bizonytalanságokat elsősorban az erődítménynek a kortársak által is leírt nagymértékű elpusztítása és az 1950-es években a Jugoszlávia ellen épülő védvonal földmunkái okozták. A bizonyosság megerősítésében jelentős lépés volt a hadszíntér kutatók bekapcsolódása, és a vár környezetében végzett vizsgálatok eredményei (HAUSNER-NÉGYESI-PAPP 2005. 835-862).

A kérdést tehát véglegesen a helyszínen végzett hadszíntérkutatás, a müszeres, és régészeti kutatások döntötték el, bizonyítva a történeti és terepbejárási adatok alapján feltételezett lokalizáció helyességét.

A Zrínyi Miklós Nemzetvédelmi Egyetem (ZMNE) oktatóinak és hallgatóinak egy csoportja, a Magyar Hadtudományi Társaság (MHTT) Csata- és Hadszíntérkutató Szakosztálya, a Hadtörténeti Intézet és Múzeum (HIM) közös kutatócsoportot hozott létre, mely a Somogy és Zala Megyei Múzeumok Igazgatóságai valamint Belezna és Őrtilos Polgármesteri Hivatalai támogatásával kísérletet tett arra, hogy fellelje Zrínyi-Újvár 1664-es ostromának nyomait. ${ }^{27}$

26 Ugyanitt. 109. jegyzetben a lokalizációval kapcsolatos irodalom rövid összefoglalása 394

27 Négyesi Lajos-Nagy Rudolf-Padányi József: Zrínyi-Újvár ostromának nyomait kerestük http://www.belezna.hu/index.php?mod=ujvar 
A Zrínyi Miklós Nemzetvédelmi Egyetem munkatársai 2004, 2006, 2007 és 2011-es években készítettek müszeres felméréseket (X.t. 5-6.). A műszeres kutatás több mint száz leletet hozott felszínre. Köztük különböző méretű ólomgolyókat, ágyúgolyó repeszeket, gránát és bomba maradványokat. A leglátványosabb egy fel nem robbant bomba volt, melynek alapján annak egykori szerkezetét is meg lehetett állapítani (X. t. 4.).

$A$ vár területén régészeti feltárásra három ütemben került sor, Vándor László (ZMMI) és Költő László (SMMI) vezetésével. A régészeti kutatás a 2006-os kisebb sáncátvágási kísérlettől eltekintve 2011-ben és 2012-ben folyt. Ez alatt az idő alatt a nagykiterjedésü erődítményen belül 102,5 négyzetmétert tártunk fel. ${ }^{28}$

Az utóbbi két év kutatásának anyagi fedezetét a Somogy Megyei Múzeumok Igazgatósága által pályázott, az NKA Műemléki és Régészeti Szakmai Kollégiumától elnyert összeg biztosította, az önrészt a Somogy- és Zala Megyei Múzeumok Igazgatósága, valamint Belezna és Örtilos önkormányzatai adták. A munkaerőt első sorban a Zrínyi Miklós Nemzetvédelmi Egyetem oktatói és hallgatói biztosították. Mindhárom feltáráson részt vettek rajtuk kívül a Hadtörténeti Intézet és a múzeumok munkatársai, egyen-egyen a SZATE és az ELTE régészhallgatói. A Katonaföldrajzi Tanszék munkatársai a topográfiai munkából vették ki részüket, míg a táborvezetői tisztet Dr. Padányi József ezredes vállalta.

A 2006. évi kutatás a várat a dombháttól elválasztó árok szélének meghatározását szolgálta, a déli védművek vonalának meghatározása céljából végeztünk régészeti feltárást. Bár az árok helye fő vonalaiban azonosítható volt, a vár törökök általi felrobbantása, valamint az 1950-es évek erődítési munkálatai a felszíni formákat nagyon eltorzította. A kutatóárok kijelölése Nováki Gyula útmutatása alapján történt, azonosítani tudtuk az egykori várárok szélét, és a müszeres felderítés során ebben az évben került felszínre a hadszíntérkutatók által talált puskagolyók jelentős része is.

$A z$ első nagyobb feltárásra 2010. július 21. és augusztus 12. között került sor a Nemzeti Kulturális Alap támogatásával. A program „Zrínyi-Újvár sáncrendszerének, belső szerkezetének kutatása" címet viselte. Célja a központi plató és a keleti védőművek közötti terület átvizsgálása és a régészeti objektumok állapotának felmérése, a források alapján a 16. századra keltezhető castellum létezésének igazolása, illetve viszonyulása a 17. századi erődítményhez, valamint a várvédők maradványait rejtő várkút beazonosítása volt.

A területen a Zrínyi Miklós Nemzetvédelmi Egyetem Geoinformációs Tanszékének munkatársai előzetesen talajradaros vizsgálatot végeztek, az ennek során kapott mérési eredményeket felhasználva került sor az ásatási szelvények kijelölésére.

28 A Hadtörténeti Intézet és a Múzeum által támogatott, 2006-ban végzett kisebb kutatásban közremüködött Nováki Gyula régész, és Szakács Géza régésztechnikus (ZMMI) Négyesi Lajos hadszíntérkutató, hadtörténész (HIM). A 2010. évi ásatáson Orha Zoltán régész (ZMMI), valamint Simmer Livia régész (ZMMI) vett részt. $A$ 2011. évi ásatás közremüködői Polgár Balázs régész (HIM) Varga. Máté (SMMI) régész technikus voltak.
A 2011. évi feltárás július 14. és augusztus 29. között szintén a Nemzeti Kulturális Alap támogatásával zajlott. Ennek során terveztük a 2010-ben megtalált kút mélyítésének folytatását, de mivel nem sikerült ehhez alkalmas szakembert találni, a 2010-ben előkerült barakképítmények kiterjedésének és szerkezetének vizsgálatára összpontosítottunk. A rendelkezésünkre álló munkaerő - régészhallgatók és egyetemi hallgatók - elsősorban a felületek aprólékos feltárására adtak lehetőséget. Emellett a területen a Zrínyi Miklós Nemzetvédelmi Egyetem Geoinformációs Tanszékének munkatársai újabb talajradaros vizsgálatára alapozva egy újabb lehetséges kút helyének vizsgálatára vállalkoztunk.

A falak átlagosan $20 \mathrm{~cm}$ vastagok voltak. Alapvetően sövényfalak voltak, a vázuk talpgerendán nyugodott, ezekbe a sarkokon vastagabb, köztük vékonyabb faoszlopokat álítottak, melyeket vesszővel befontak, néhol deszkával borítottak, helyenként összeszögeltek és betapasztottak. A talpgerendák általában egyszerüen a fölbe, néhány helyen azonban nagyobb folyami kavicsokra voltak fektetve. A falak maradványait különböző állapotban találtuk meg. Egyes helyeken már csak az alapozó árok volt megfigyelhető, de a néhány esetben a felmenő fal $30-50 \mathrm{~cm}$-es magasságig megmaradt. Több esetben sikerült megfigyelni a faszerkezetek lenyomatait a tapasztásban (X. t. 3.), néhol viszont az elszenesedett vesszőfonatokat is sikerült dokumentálni. Az ásatási megfigyelések alapján valószínűsíthetjük, hogy az épületet az elhagyása előtt teljesen kiürítették.

A feltáráson elökerült leletek túlnyomó többségét kerámia alkotja. Az épületben talált kerámialeletek jórészt mázatlan, jól iszapolt agyagból készült, vöröses színű edények, tál alakú kályhaszemek, valamint kályhacsempék töredékei voltak. A kályhacsempék előlapját griffes, oroszlános, lovagalakos ábrázolás, vagy növényi ornamentika díszítette (XI. t.)

$A z$ ásatáson előkerült leletek közül fontosak a fegyverleletek (főképpen puska- és ágyúgolyók), melyek zömmel az ostrommal hozhatók kapcsolatba. Ezek közé tartozik egy, az épületek belsejében, a járószinten megtalált töltetlen bomba.

Kiemelkedően fontos az eddig egyetlen korabeli érem, III. Ferdinánd (1637-1657) által 1648-ban veretett ezüst garas (X. t. 1a-b.). A 2010-2011. évi ásatás során előkerült leletanyag megismerésével fontos adatokhoz jutottunk a 17 . század közepi régészeti anyag meghatározásával kapcsolatosan is, hiszen az itt talált tárgyak bizonyosan 1661. június 14. - 1664. július 7 . között kerültek a földbe.

A kutatás során elökerült ólom lövedékeken a MTA Debreceni Atommag Kutató Intézetében Kis Varga Miklóssal végeztünk elemanalízist, melynek során kiderült, hogy a török és a magyar puskagolyók elemi összetételében különbségek találhatók. Ez arra enged következtetni, hogy bár valószínűleg újrahasznosíthatták az ellenségtől megszerzett hadianyagokat, a hadviselő feleknek mégis saját nyersanyagforrással is kellett rendelkezniük. 
Feltétlenül fontos lenne a feltárás folytatása, a vár belső szerkezetének, sáncrendszerének teljes tisztázása. Reméljük, erre a jövőben sor fog kerülni, mint ahogy arra is, hogy a részt vevő horvát és magyar intézmények, te- lepülések szándéknyilatkozatának megfelelően bizonyos rekonstrukciós munkálatok is elvégezhetők lesznek, az idegenforgalomba is bekapcsolhatjuk az immár teljes bizonyossággal azonosított történelmi emlékhelyünket.

\section{Irodalom}

M. ARADI Cs. 2007: Somogy megye Árpád-kori és középkori egyházszervezetének létrejötte és megszilárdulása. Doktori (Phd) disszertáció 2007.

BAKAY K. 2011: Somogyvár. Szent Egyed monostor. MNG. 2011 Budapest BÁRDOS, E. \& GARAM, É. 2009: Das awarenzeitliche Gräberfeld in ZamárdiRétiföldek. - Monumenta Avarorum Archeologica. Vol. 9. Budapest 2009.

BónA I. 1988: Vázlat a lakóházak történetéröl a Kárpát-medencében. Bírálat Barabás Jenő: Fordulatok és korszakok a magyar népi építészetben c. doktori értekezéséről. - Ethnographia XCIX. Budapest, 1988. 401-411.

BoRsA I. 1998: A somogyi konvent oklevelei az Országos Levéltárban. 1351-1370. - Levéltári közlemények Somogy Megye múltjából. 29. Kaposvár. 1998. 3-40.

BudAI BALOGH, T. 2009: Pannonische Grubenhäuser. Abriss der Römerzeitlichen Geschichte der Eingetieften Wohnhauser. - In: Ex Officina. Studia in honorem Dénes Gabler. Györ, 2009. 77-110.

Cencic, J. 2004: Römische Wohnbauten in Carnuntum. - Carnuntum Jahrbuch 2003. Wien, 2004. 9-116.

CSÁNKI D. 1890: Magyarország történeti földrajza a Hunyadiak korában. I-III., V. 1890-1913. (IV. Fekete Nagy Antal, 1941.) II. Somogy megye. Budapest, 1890.

DinNYÉs I. 1997: A Nyáregyházi 6. és 16. lelőhely szarmata házai. - In: Kutatások Pest megyében. Tudományos Konferencia I. Szentendre, 1997. 367-373.

Donat, P. 1988: Probleme der Erforschung Kaiserzeitlich-völkerwanderungszeitlicher Haus- und Siedlungsformen zwischen Elbe/Saale und Weichsel. - Slavia Antiqua XXX. Warszawa-Poznan, 1988. $1-50$.

DroberJaR, E. 1997: Studien zu den Germanischen Siedlungen. Die Älteren römischen Kaiserzeit im Mähren. - Fontes Archaeologici Pragenses 21. Praha, 1997.

GABLER D. 1980/1981: Forschungen in der Späteisenzeitlich-römerzeitlichen Siedlung von Szakály. - Mitteilungen des Archäologischen Instituts der Ungarischen Akademie der Wissenschaften 10/11. Budapest, 1980/81. 71-101.

GABLER D. 1982: Aspects of the Development of Late Iron Age Settlements in Transdanubia into Roman Period at Szakály. - In: Studies in the Iron Age in Hungary. B.A.R. International Series 144. London, 1982. 57-127.

HAVASSY P. és G. VIzı M. 2004: Árpád-kori templom maradványai Regölyben. - In: „Quasi liber et pictura”. Tanulmányok Kubinyi András hetvenedik születésnapjára. Szerk. Kovács Gyöngyi. Bp. 2004. 221-234.

Hausner G., NÉgYesı L. és PApp F. 2005: „Juhakol” a szőlőhegyen. Kísérlet Zrínyi Újvár helyzetének meghatározására. - Hadtörténeti Közlemények 118.évf.3,sz./2005. 835-862.

$\mathrm{HO}=$ Hazai Okmánytár / Codex diplomaticus patrius. Szerk. IPOLYI A. NAGY I. - PAUR I. - RÁtH K. - VÉGHely D. I-VII. 1865-1891. Győr

Hontı et al. 2006: Hontı Sz. - FÁbiÁn Sz. - Gallina Zs. - Hajdú Á. D. Hornok P. - Soós I. - Mersdorf Zs. - Molnár I. - Németh P. G. - Polgár P. - P. Szeöke J. - Serlegi G. - Siklósı Zs. - Sipos C. - SoMOGYI K. 2006.: Régészeti kutatások az M7-es autópálya Somogy megyei szakaszán és a 67-es úton (2004-2005) Előzetes jelentés IV - Archaeological research on the Somogy county section of the M7 highway and on Route No. 67. Preliminary report IV. - Somogyi Múzeumok Közleményei 17. (2006) 7-70.

HoRvÁTH L. 1987: Késővaskori ház és település típusok Dél-Zalában. - Zalai Múzeum 1. Zalaegerszeg, 1987. 59-81.

HoRvÁtH P. és TótH Zs. 1993: Csatok és könyvveretek a könyvtáblákon: történeti áttekintés. - In: Horváth P. - Kastaly B. - Tóth Zs. szerk. A könyv- és papírrestaurátori tanfolyam jegyzetei. 5-103.

HRENKó P. 1979: Zrínyi-Újvár (Újzerinvár) helyszínrajzai nyomában. - Geodézia és Kartográfia 1979. 2. szám, 119-134.
H. Kocztur É. 1972: Újabb adatok Gorsium őslakosságának háztípusaihoz. - In: Folia Archaeologica 23. Budapest, 1972. 43-57.

KocztuR É. 1964: Somogy megye régészeti leletkatasztere. Régészet füzetek. II/13. (1964) 1-163.

KöLtő L. és BAJZIK A. 2008: Kora Árpád-kori temetörészlet egy kaposvári lakóparkban. Előzetes jelentés az Ezüsthárs lakópark közmüberuházások által érintett területének régészeti feltárásáról Early Árpád-era cemetery section in a housing park in Kaposvár. Preliminary report on the archaeological survey of areas affected by public utilities instalment in the Ezüsthárs housing block. Somogyi Múzeumok Közleményei 18: 171-224.

KUMOROVITZ L. B. 1953: Veszprémi regeszták, 1301-1387.

KuzmovA, K.1980: Nižinné sídliska z neskorej doby Laténskej v Strednom podunajsku. - Slovenská Archeológia XXVIII/2. Bratislava, 1980. 312-337.

LeUbE, A. 1992: Studien zu Wirtschaft und siedlung bei den germanischen Stämmen im nördlichen Mitteleuropa während des 1.-5./6. Jh. u. Z. - Ethnographisch-Archäologische Zeitschrift 33. Berlin, 1992. 130-146.

Lukcsıcs P. 1931: XV. századi pápák oklevelei. I. 1931. Budapest

MAGYAR K. 1985: Az utolsó magyar polihisztor. Fonyód régésze: Bacsák György - In.: Fonyód története. Szerk. Kanyar J. 5-23.

IRÁSNÉ MELIS K. 1986: A Mátyás kori budai királyi könyvkötömühely leletei. - Müvészettörténeti Értesítő 1985. XXXIV. Évf. 1-2: 48-60.

MıKLós Zs. és VıZı M. 1999: Előzetes jelentés a középkori Ete mezőváros területén végzett kutatásokról. - Vorläufiger Bericht über die Ausgrabungen im mittelalterlichen Marktflecken Ete. - Wosinszky Mór Múzeum Évkönyve 21: 207-269.

Mon. Rom. = Fraknóı V. és Lukcsics J. (szerk.): Monumenta Romana Episcopatus Vespremiensis. I-IV. 1896-1907

MoN. VAT. = Fraknói Vilmos (szerk.): Monumenta Vaticana historiam regn Hungariae illustrancia. Series I. Tom. 1-5. 1887-1889. Budapest

Nagy Á., Gallina Zs., Molnár I. és Skriba P. 2001: Késő Árpád-kori, nagyméretű, földbemélyített építmények Ordacsehi-Bugaszegen. Grosse, gegrabene Bauten in Ordacsehi-Bugaszeg aus der späten Arpadenzeit. - In: Népi építészet a Kárpát-medencében a honfoglalástól a 18. századig. Szerk.: Cseri M. - Tárnoki J. SzentendreSzolnok 2001, 187-220.

NÉGYESI L., NAGY R., és PADÁNYI J.: Zrínyi-Újvár ostromának nyomait kerestük http://www.belezna.hu/index.php?mod=ujvar

NÉMETH P. G. 2007a: A Balaton déli partvidéke és a Dél-Dunántúl a római korban. - In: Gördülő Idő. Kaposvár, 35-40.

NÉMETH P. G. 2007B: A Balaton déli partvidéke és a Dél-Dunántúl a vaskorban. - In: Gördülö Idő. Kaposvár, 2007. 41-46.

OTTOMÁNYı K. 2007: A pátyi római telep újabb kutatási eredményei. - Studia Comitatensia 30. Régészeti Tanulmányok. Szentendre, 2007. 7-239.

OTTOMÁNYI K. 2005: Die spätlatenezeitlich-römische Siedlung von Budaörs. - Acta Archaeologica Hungarica LVI. Budapest, 2005. 67-132.

PEST: Pest megye monográfiája. I. kötet. Első rész. A kezdetektől a honfoglalásig. Pest megye régészeti emlékei. Szerk.: Fancsalszky G., Budapest, 2007

T. SZÖNYI E. 1996: Römerzeitliche Altansassigensiedlung von Ménföcsanak (Umgebung von Győr) - Arheologica Vestnik 47: 249-256.

VÁNDOR L. 1972: A Mura völgy magyarországi szakaszának településtörténete, 1972. Szakdolgozat. ELTE Régészeti tanszék Könyvtára, Göcseji Múzeum Adattár. 498-912.

VÁNDOR L. 1994: Nagykanizsa története a honfoglalástól a török alóli felszabadulásig Nagykanizsa. Városi monográfia. Első kötet. Nagykanizsa 1994.

VÉGH J. 1974: Végh J. (szerk.): Somogy megye földrajzi nevei. 1974. Budapest. 


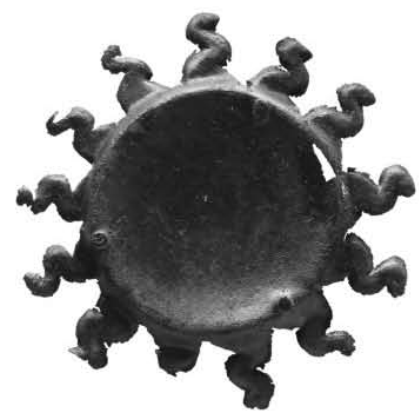

$1 \mathrm{a}$

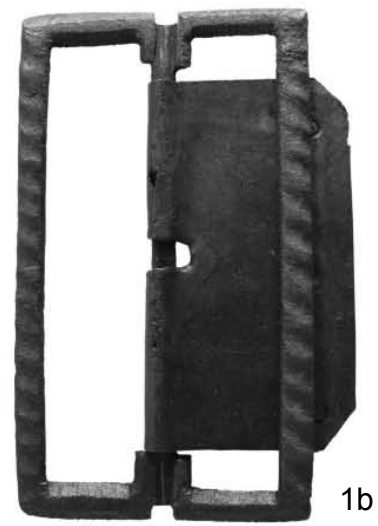

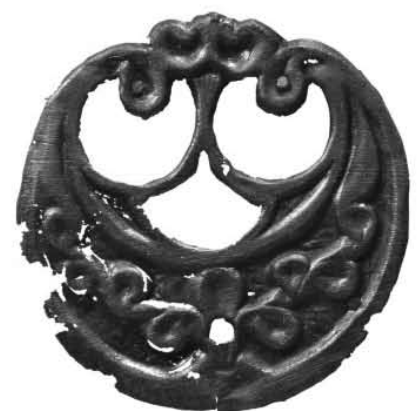

1c

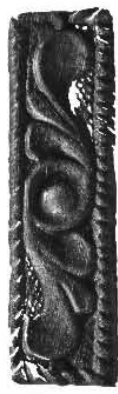

$1 \mathrm{~d}$

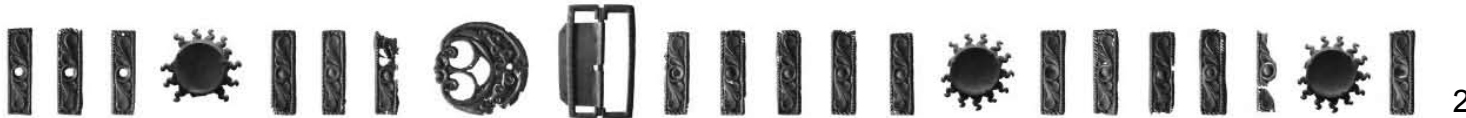
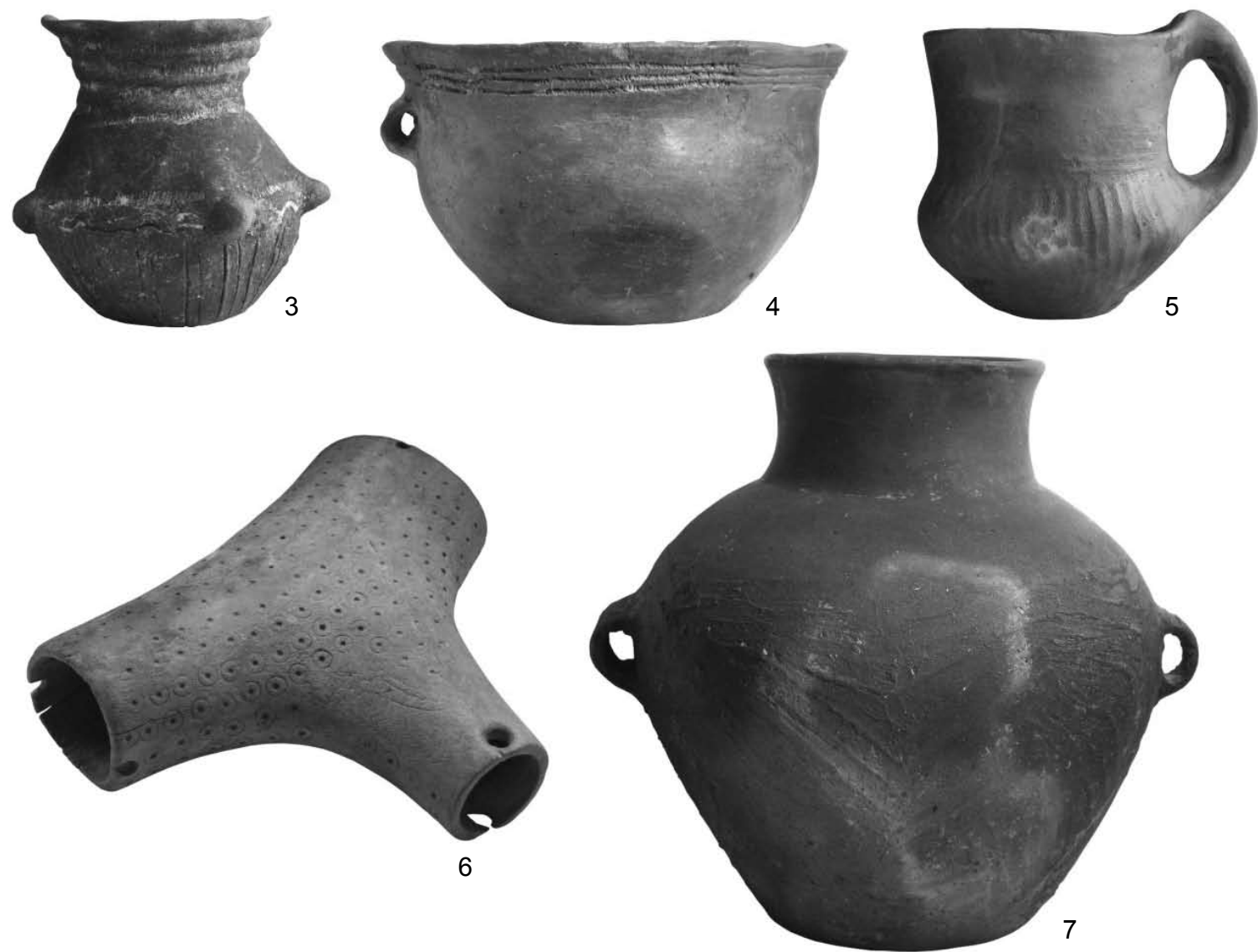

I. tábla: 1-2. Kisberény - Helai-dülő: Övveretek az 5. sírból és övrekonstrukció;

3-5. Kaposvár-Kisgát III. ütem: 3-4. bronzkori edények, 5. késő-rézkori bögre; 6. Csont sótartó a Vörs-B temetőből; 7. Korabronzkori sírmelléklet Zamárdiból 

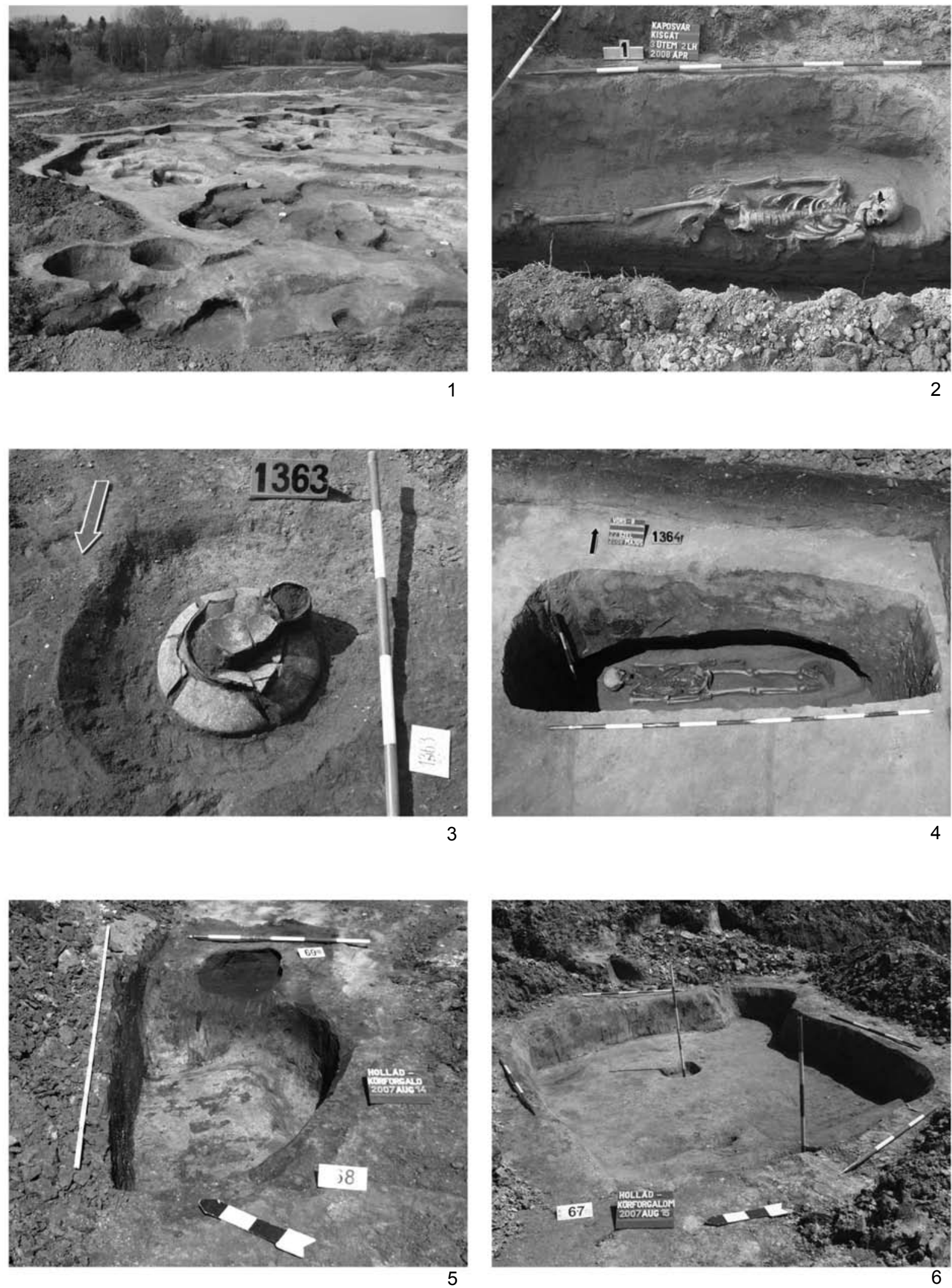

II. tábla: 1-2. Kaposvár-Kisgát: Nagyméretü korabronzkori objektum és kora-újkori sír; 3-4. Vörs-Battyáni-disznólegelö: Az 1363. későbronzkori urnasír és az 1364. padmalyos avar sír; 5-6. Hollád körforgalom: Kora-Árpád-kori kemence és félig földbeásott épitmény 

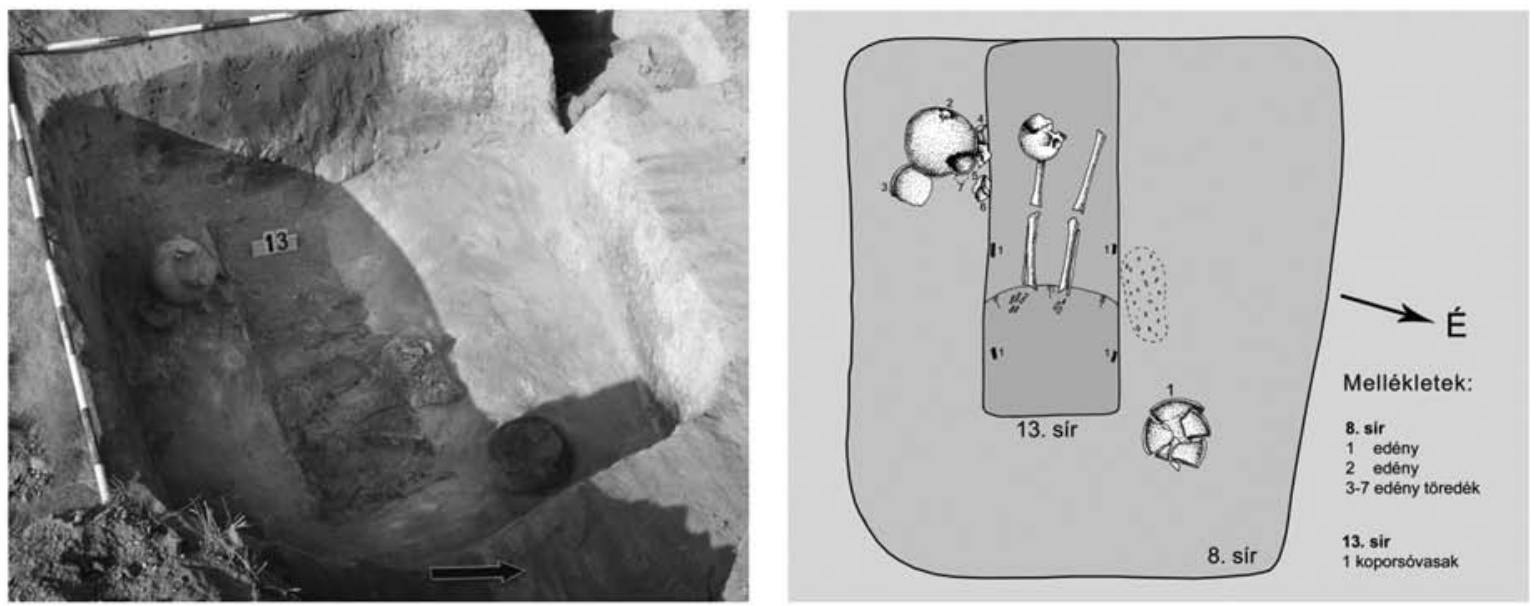

1

2
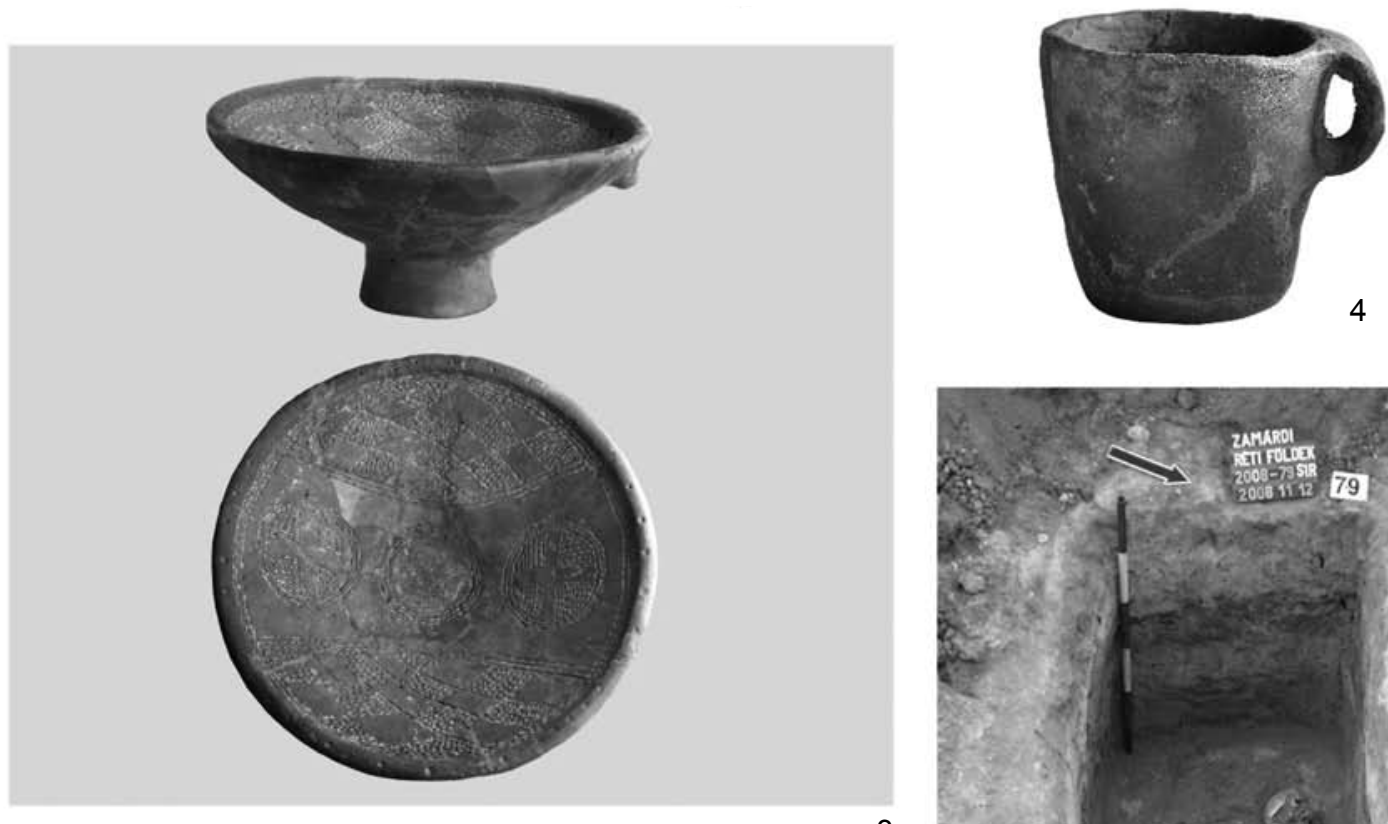

3
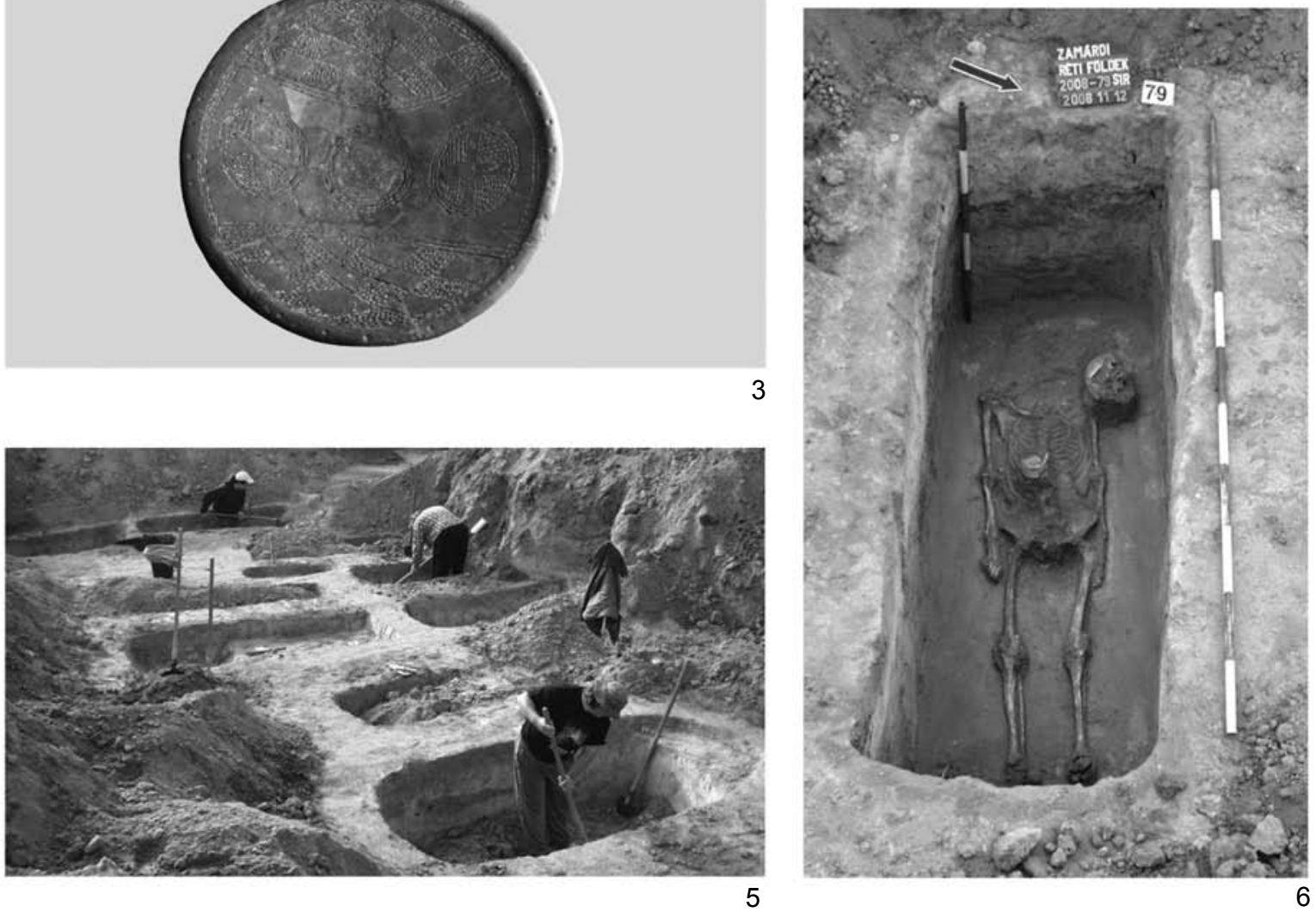

III. tábla: 1-6. Zamárdi-Réti-földek, 2008: 1-4. A 8. korabronzkori sír és edénymellékletei; 5. A temetörészlet feltárása; 6. A 79. avar sír 


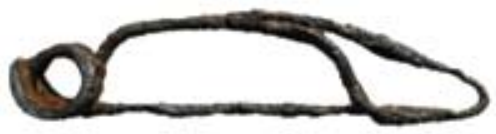

1
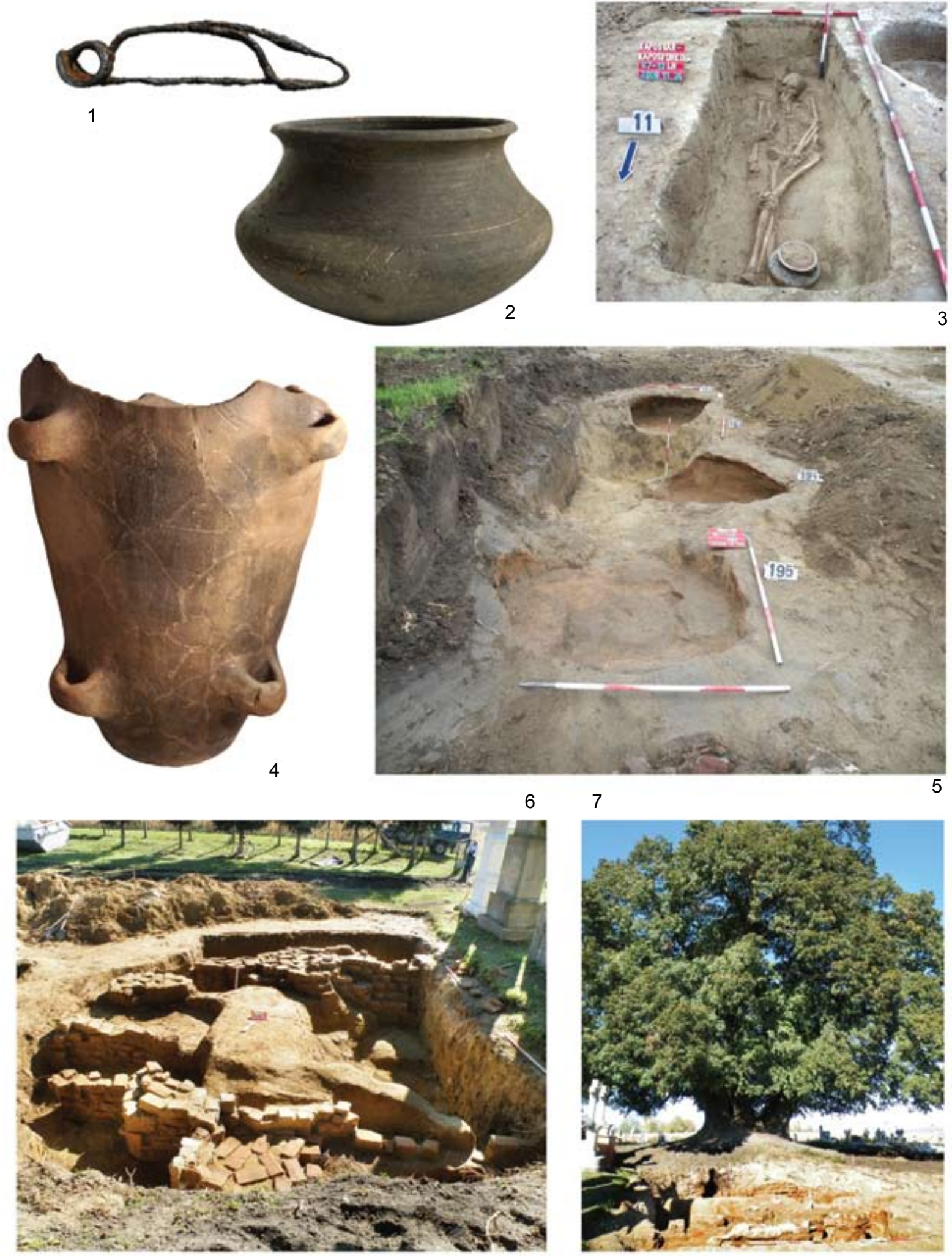

IV. tábla: 1-3. Kaposvár-Kaposfüred 67/13. lelőhely: kelta sír; edény és vasfibula a sírból; 4. Gyékényes - Fehér-dülő: középső rézkori edény; 5. Siófok-Körforgalom, avar-kori kemencebokor; 6-7. Szőkedencs-temető: A 700 éves hársfa a feltárás részletével és a templom szentélye északról 

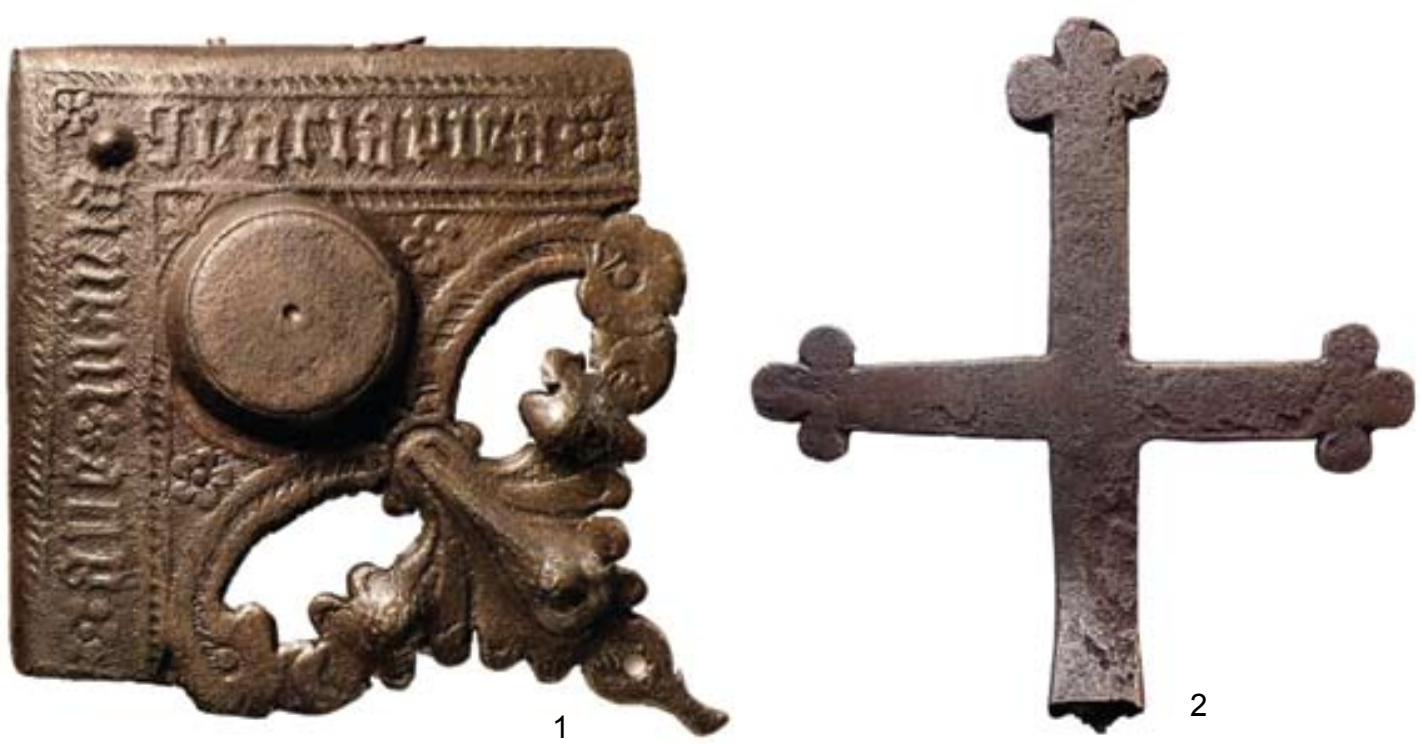

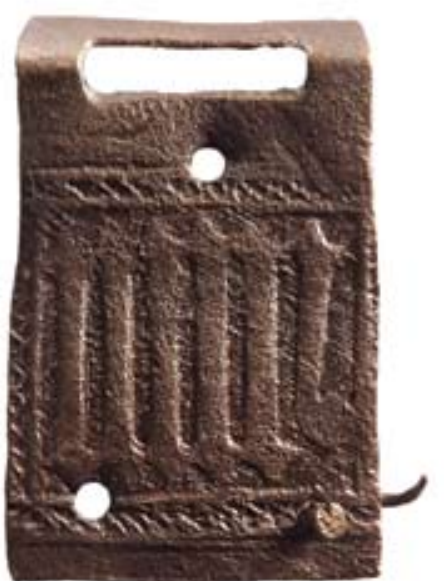

3
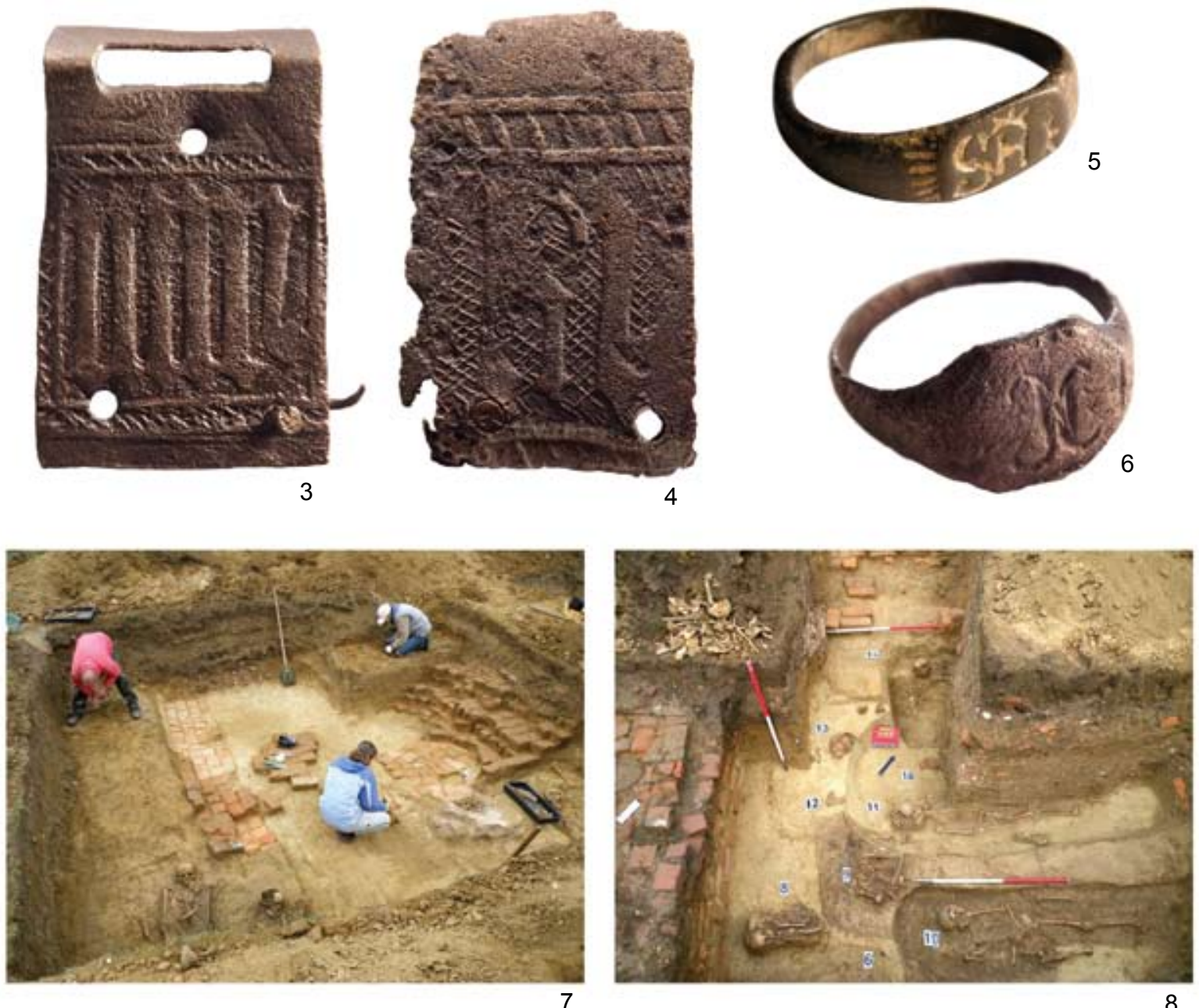

V. tábla: 1-6. Iharos-temető: Középkori bronz könyvveretek és könyvcsat, gyürük és kereszt a feltárásból; 7. A templom feltárása; 8. A templom körüli temetö részlete 

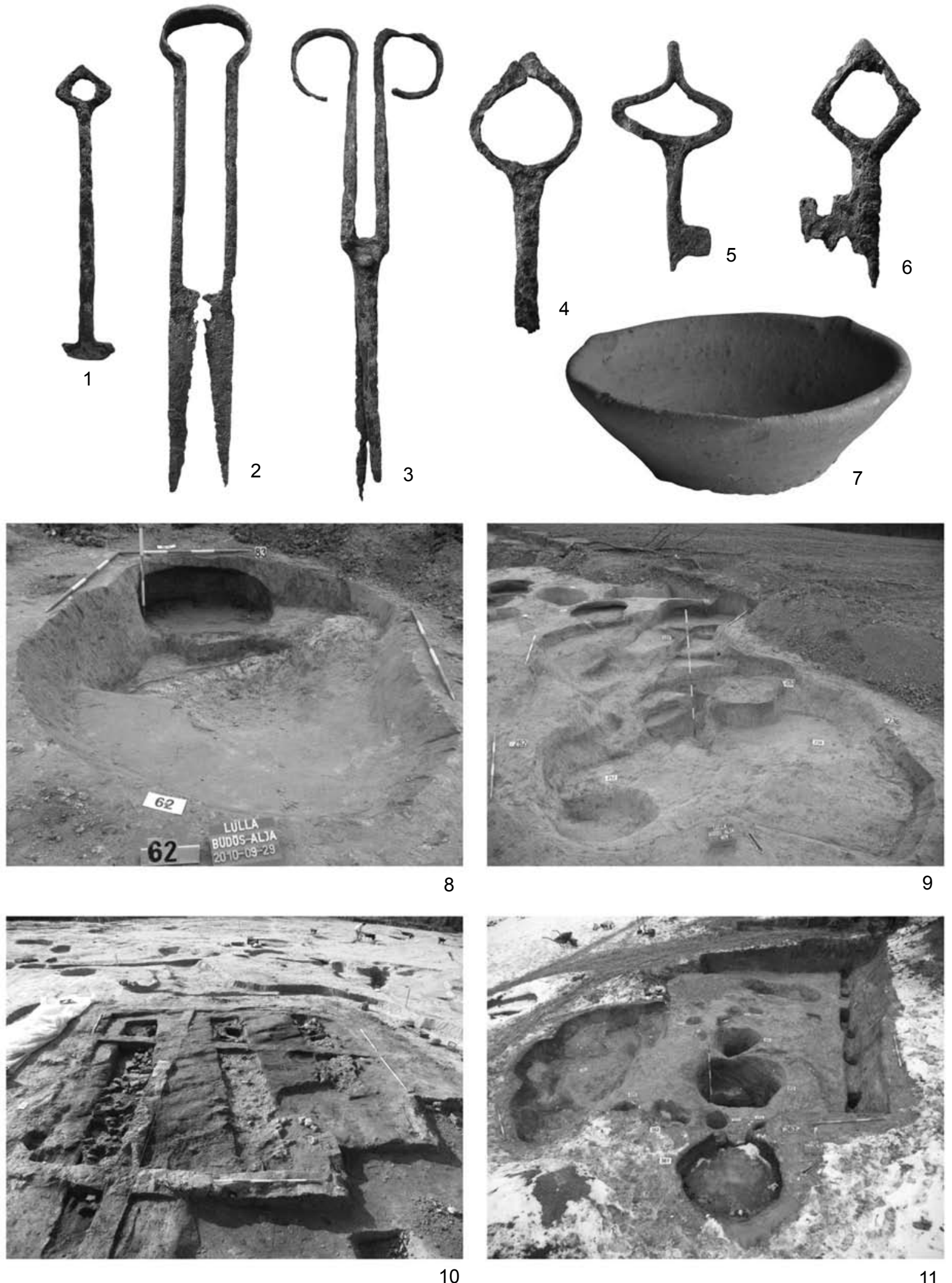

VI. tábla: Lulla-Büdösalja: 1-6. Középkori ollók és kulcsok; 7. Cserépmécses;

8. Árpád-kori kemence; 9. Kelta kemencebokor; 10. Kora újkori téglaégető kemence; 11. Árpád-kori földbevájt épület 

NÉMETH PÉTER GERGELY - SIPOS CARMEN

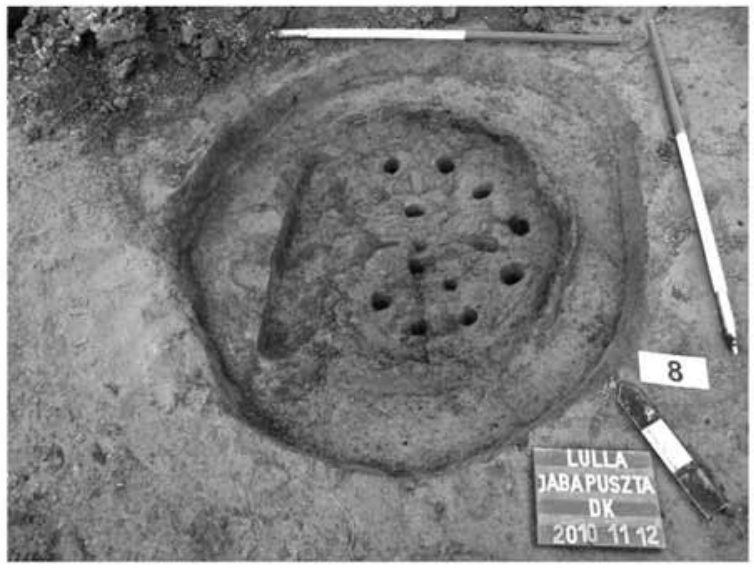

1

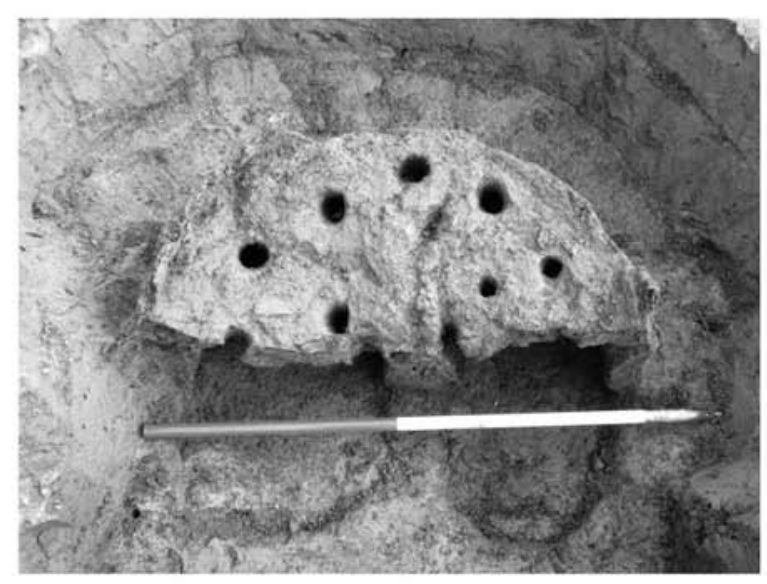

2

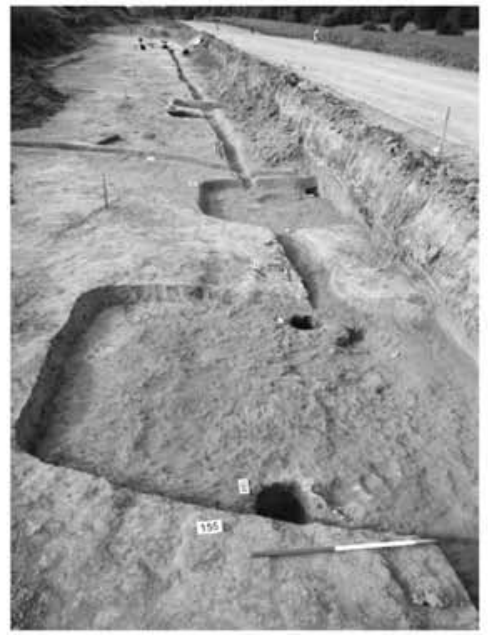

3

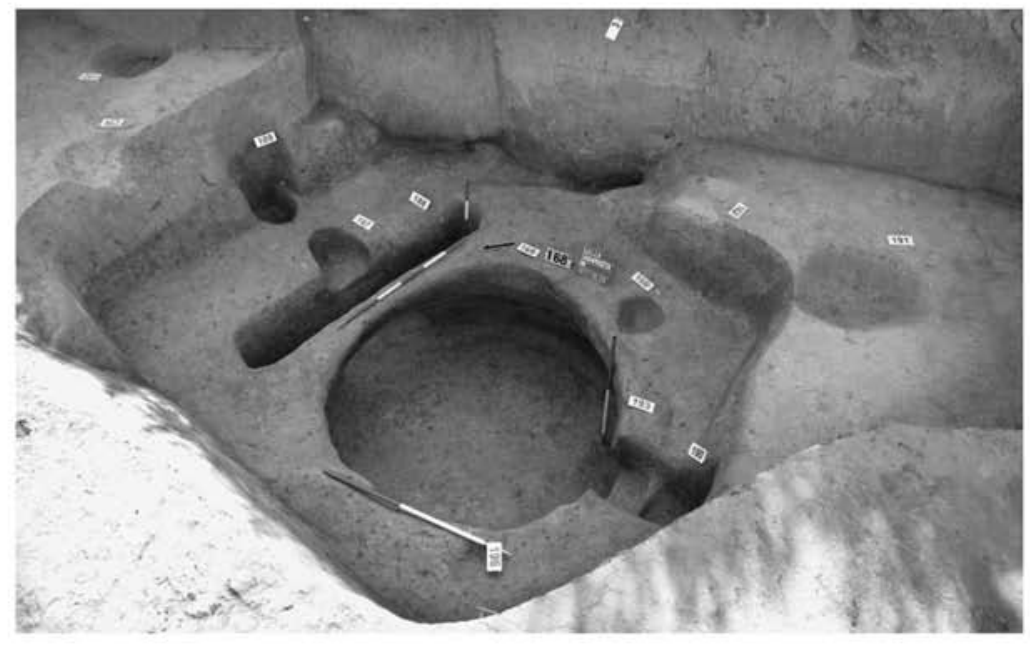

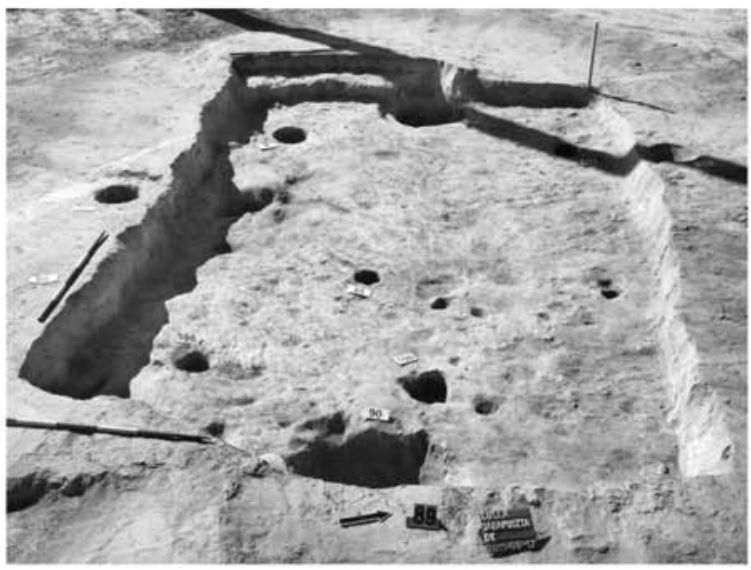

5

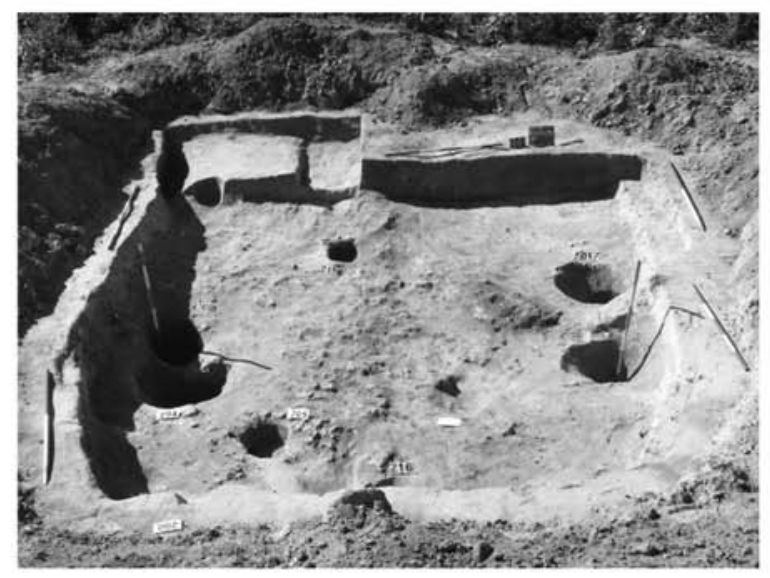

6

VII. tábla: Lulla-Jabapuszta DK: 1-2. Kora római edényégető kemence és metszete; 3-6. kora római földbe mélyített épületek 

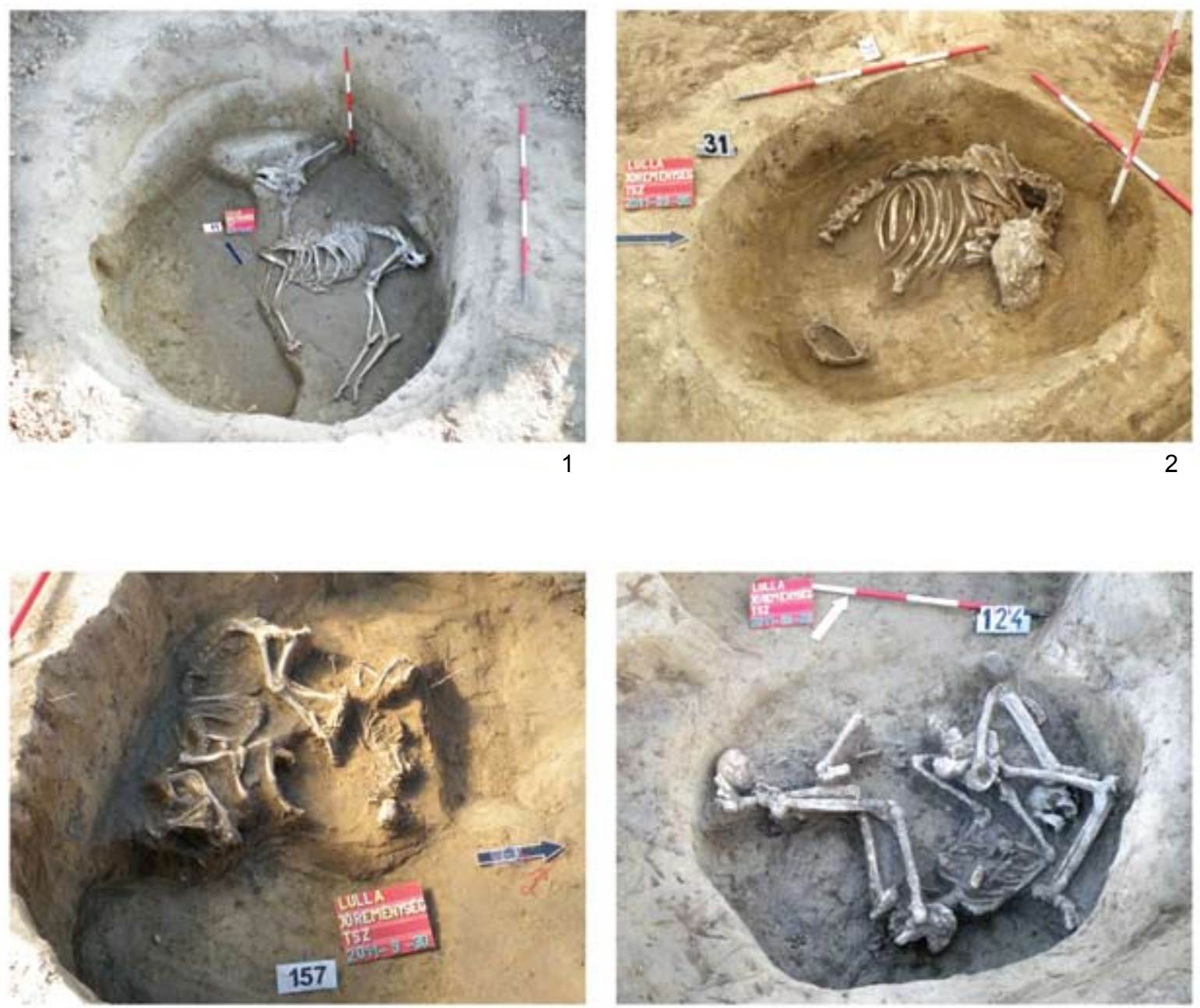

3
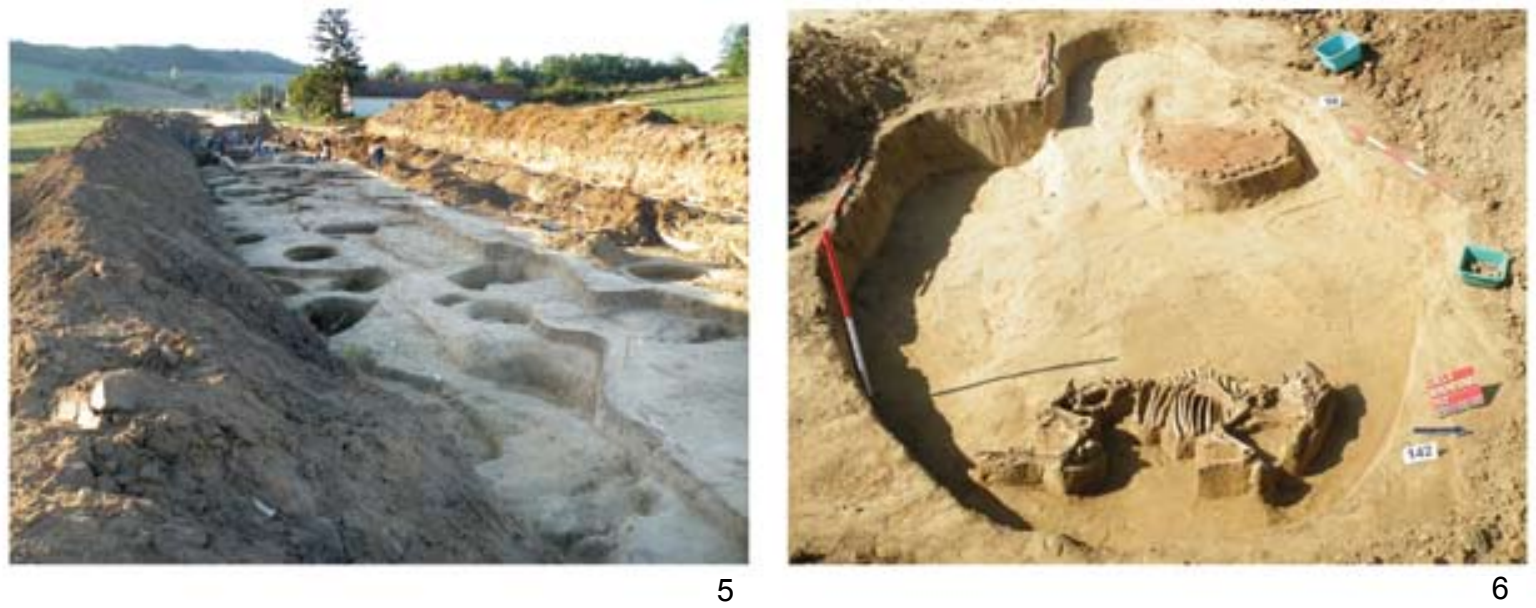

VIII. tábla: Lulla-Jabapuszta - Jóreménység Tsz: 1-2, 6. Késő rézkori gödrök, állattemetkezésekkel; 3-4. Késő rézkori áldozati gödrök; 5. Nagyméretü késő rézkori objektum bontása 


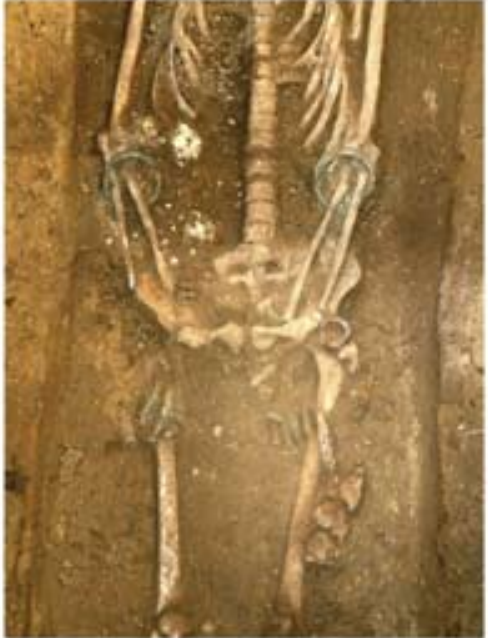

1
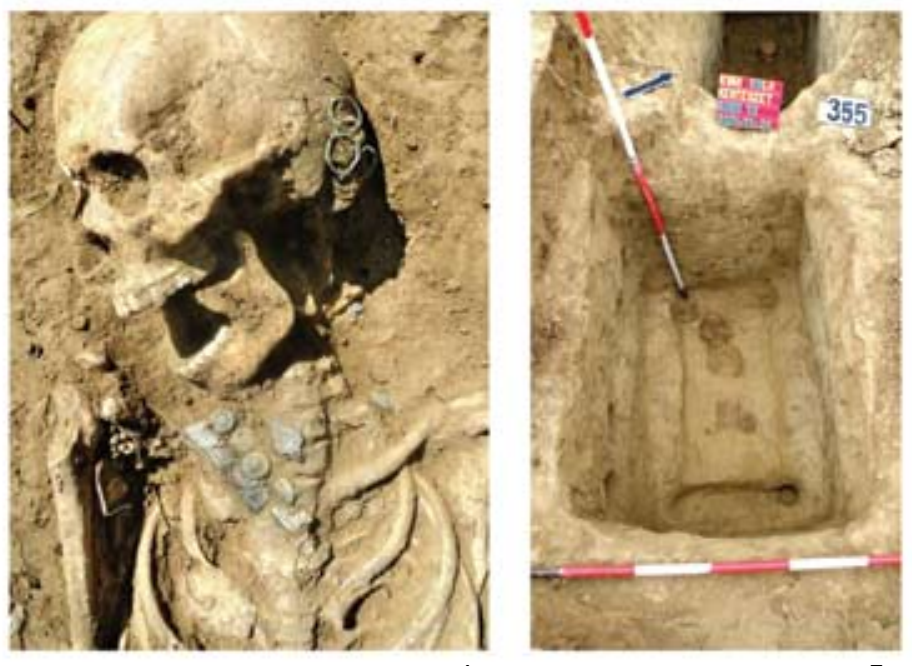

5

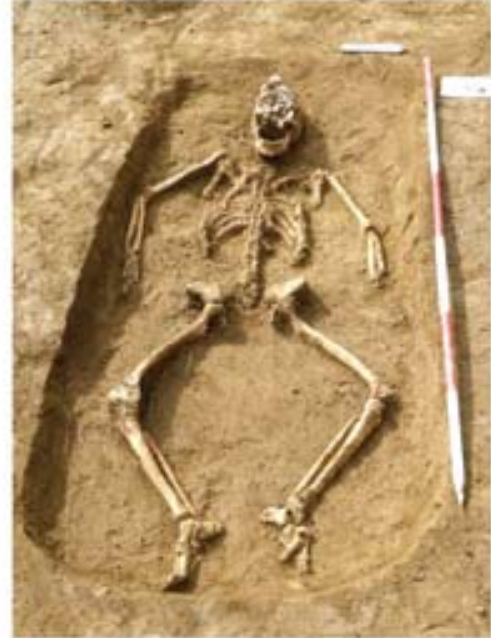

3
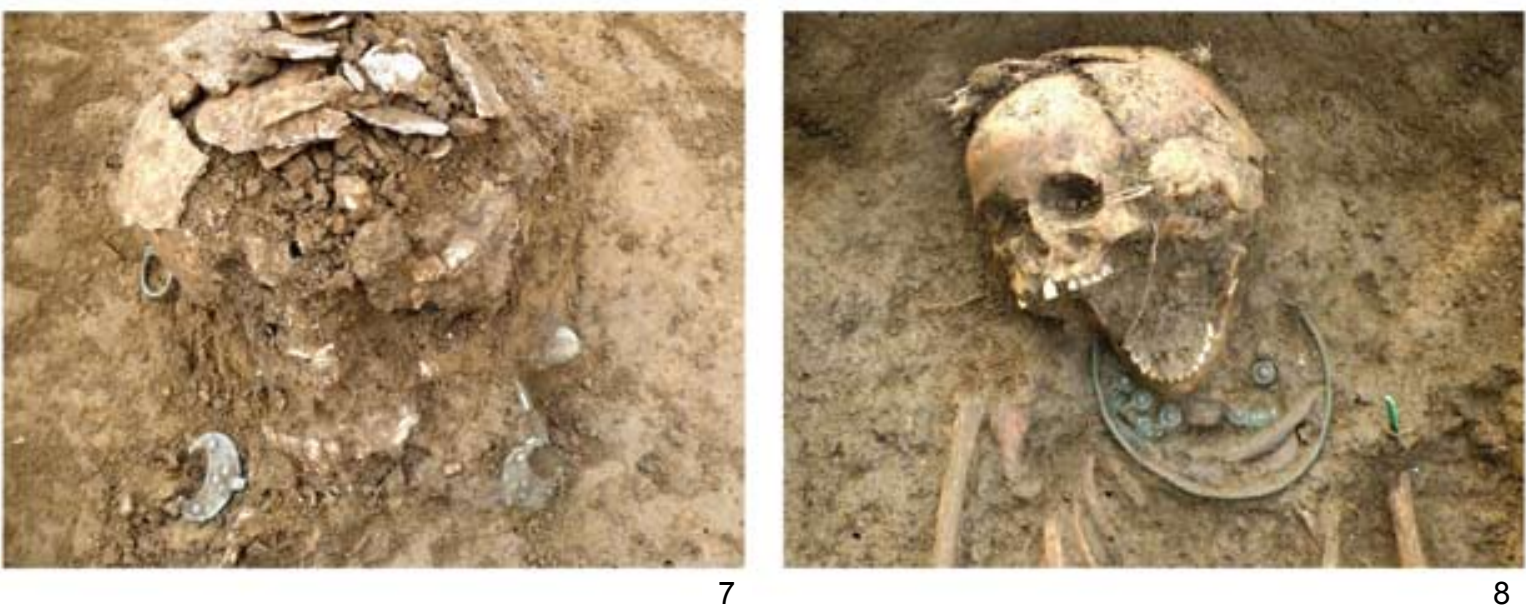

7

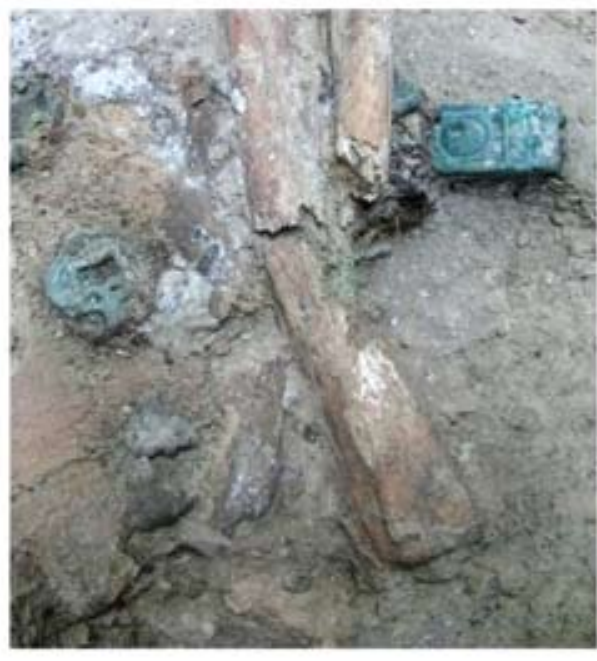

IX. tábla: Kaposvár-Kertészet: 1-2, 5-6. avar temetkezések; 3-4, 7-8. Kora-Árpád-kori sírok 1. 429. sirr, 2. 402. sír, 3. 231. sír, 4. 418. sír, 5. 355. sír, 6. 345. sír, 7. 334. sír, 8. 252. sír 

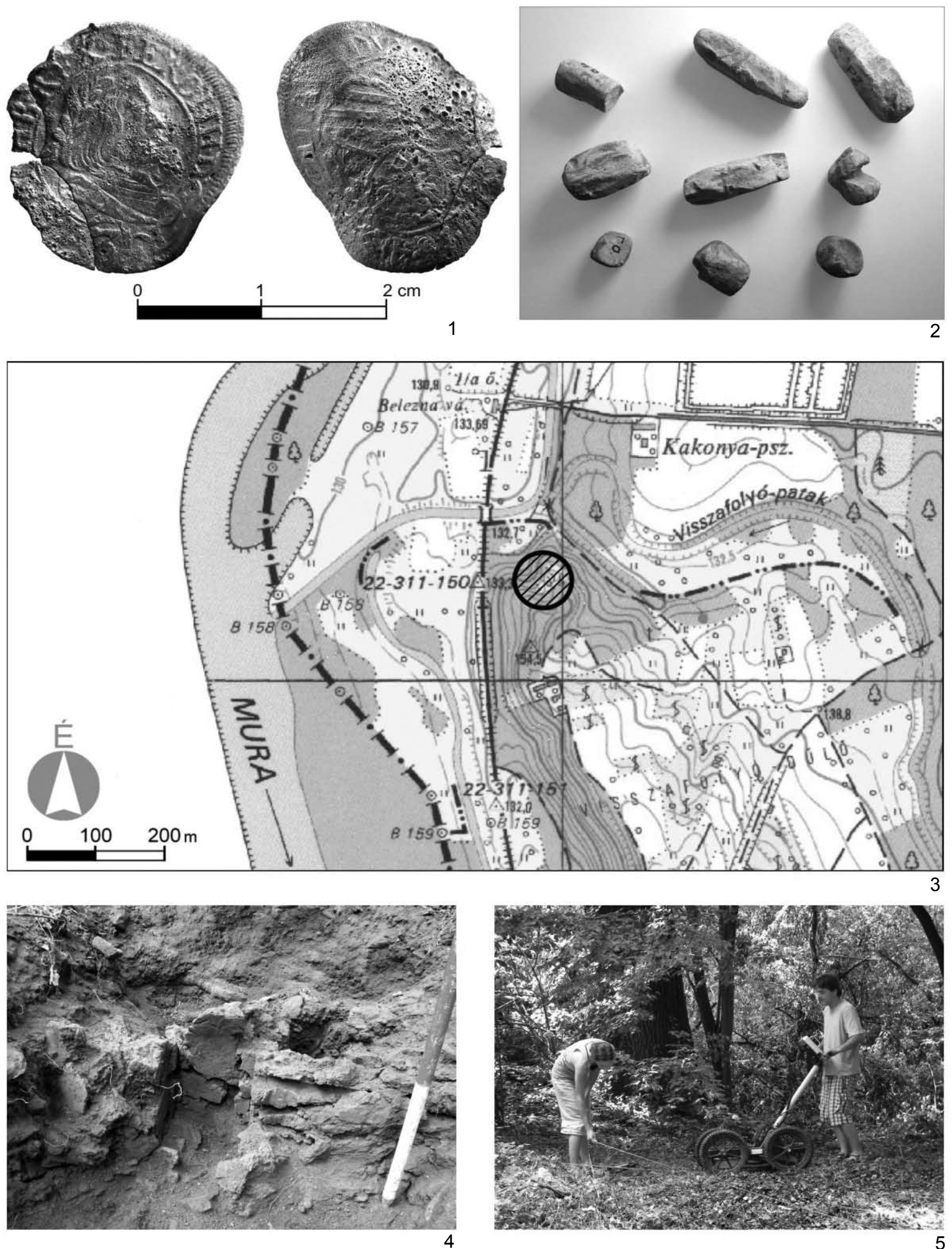

X. tábla: Örtilos-Zrinyi-Újvár

1. II. Ferdinánd garasa, 2. félkész puskagolyók; 3. A lelőhely és környezetének térképe; 4. Faszerkezet lenyomata a várban; 5 . A vár felmérése 

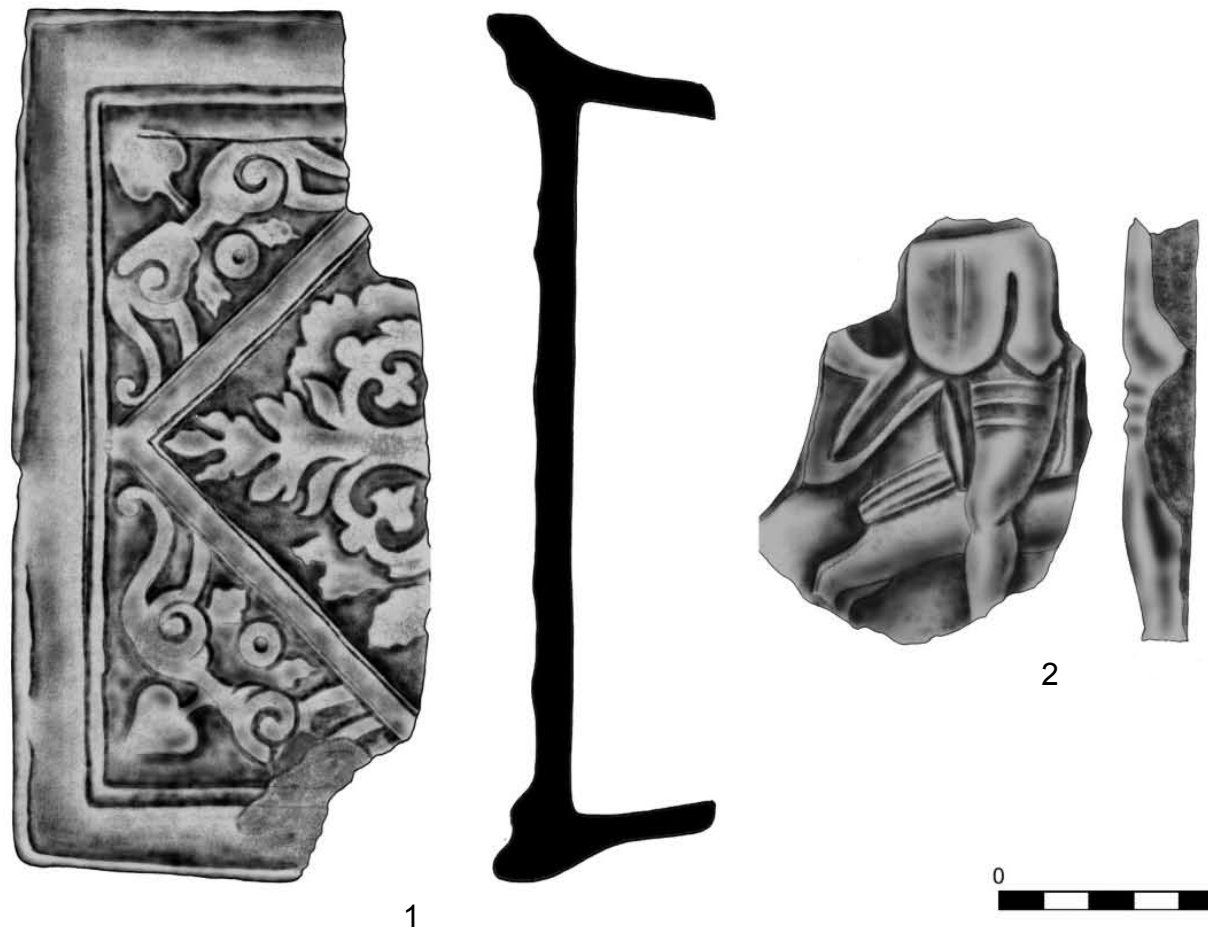

2
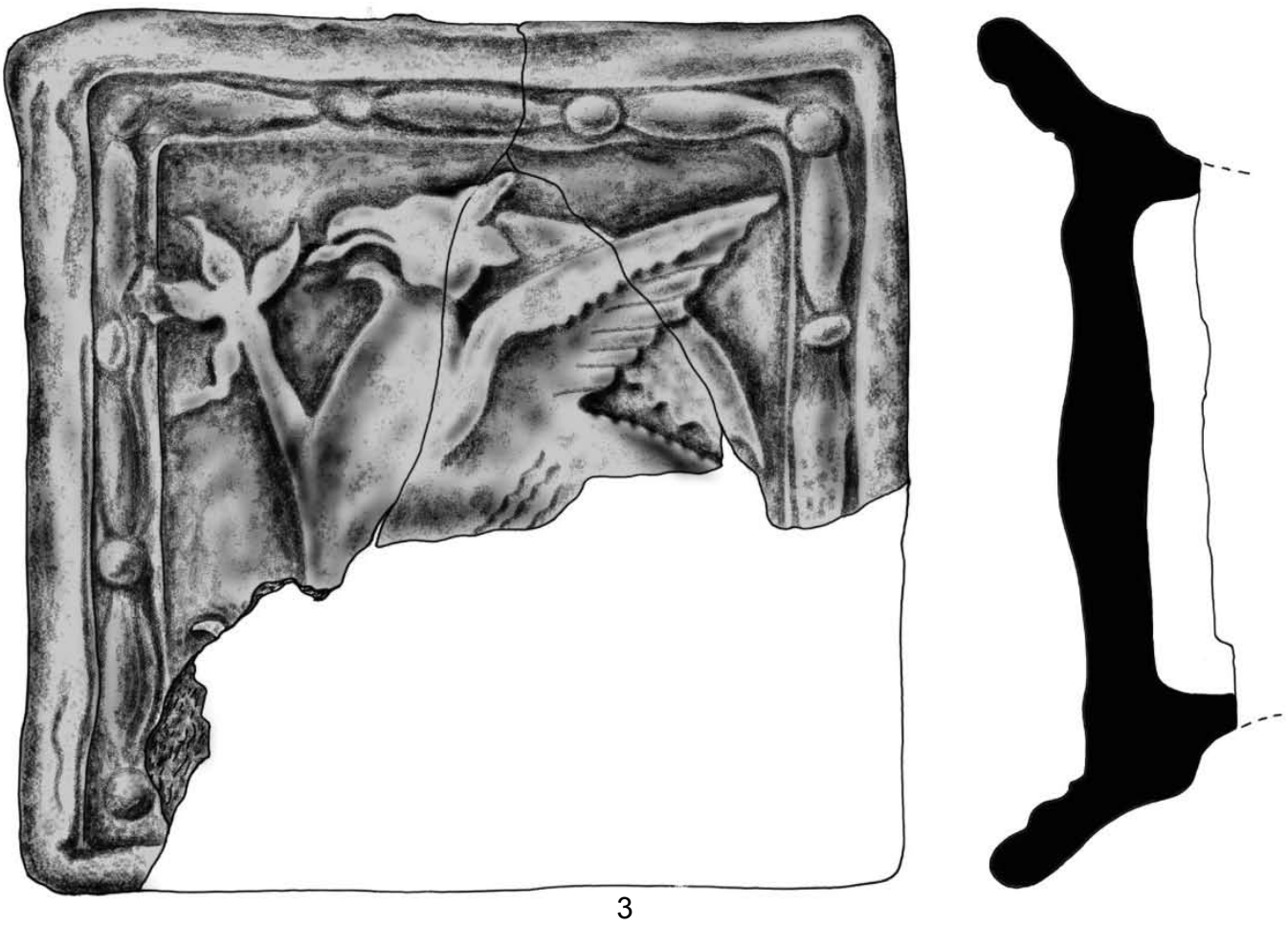

XI. tábla: Mázas kályhacsempék a várból 